\title{
Holocene landform evolution and natural site formation processes at the West Blennerhassett archaeological site (46WD83-A), Wood County, West Virginia
}

\author{
Ryan W. Robinson \\ West Virginia University
}

Follow this and additional works at: https://researchrepository.wvu.edu/etd

\footnotetext{
Recommended Citation

Robinson, Ryan W., "Holocene landform evolution and natural site formation processes at the West Blennerhassett archaeological site (46WD83-A), Wood County, West Virginia" (2009). Graduate Theses, Dissertations, and Problem Reports. 4520.

https://researchrepository.wvu.edu/etd/4520

This Thesis is protected by copyright and/or related rights. It has been brought to you by the The Research Repository @ WVU with permission from the rights-holder(s). You are free to use this Thesis in any way that is permitted by the copyright and related rights legislation that applies to your use. For other uses you must obtain permission from the rights-holder(s) directly, unless additional rights are indicated by a Creative Commons license in the record and/ or on the work itself. This Thesis has been accepted for inclusion in WVU Graduate Theses, Dissertations, and Problem Reports collection by an authorized administrator of The Research Repository @ WVU. For more information, please contact researchrepository@mail.wvu.edu.
} 
Holocene Landform Evolution and Natural Site Formation Processes at the West Blennerhassett Archaeological Site (46WD83-A), Wood County, West Virginia

\author{
Ryan W. Robinson
}

Thesis submitted to the Eberly College of Arts and Sciences at West Virginia University in partial fulfillment of the requirements for the degree of Master of Arts in Geography

\author{
J. Steven Kite, Ph.D., Chair \\ Timothy A. Warner, Ph.D. \\ James A. Thompson, Ph.D. \\ Department of Geology and Geography
}
Morgantown, WV
2009

Keywords: alluvial sediments, fluvial geomorphology, geoarchaeology, Ohio River Valley

Copyright 2009 Ryan W. Robinson 


\begin{abstract}
Holocene Landform Evolution and Natural Site Formation Processes at the West Blennerhassett Archaeological Site (46WD83-A), Wood County, West Virginia
\end{abstract}

\author{
Ryan W. Robinson
}

This study utilizes sedimentary, pedological, and archaeological data recovered from the West Blennerhassett site (46WD83-A), a deeply stratified archaeological site located at Blennerhassett Island, an Ohio River island in Wood County, West Virginia, to determine a site-specific history of landform evolution and natural site formation processes. Archaeological investigations were conducted at West Blennerhassett by the Cultural Resources Section of Michael Baker Jr., Inc. in 2002 and 2003 as part of the environmental studies for the U.S. Route 50 Blennerhassett Bridge Project for the West Virginia Division of Highways and the Federal Highways Administration. These investigations revealed stratified archaeological deposits extending to a minimum of $5 \mathrm{~m}$ in Holocene alluvium and dating from approximately 8660 B.P.

Results of particle-size analysis, bolstered by a robust radiocarbon chronology, indicate that the West Blennerhassett site was a rapidly accreting, dynamic, near-channel environment from at least 8660 to 7010 B.P. Rapid sedimentation and high-energy floods gave way to a more quiescent setting at ca. 7010 B.P., apparently as a result of vertical accretion of the site coupled with vertical incision and, possibly, lateral migration of the Ohio River channel. Alluvial sedimentation rates remained slow and the site was dominated by a low-energy overbank flood regime until ca. 3000 B.P. A distinct discontinuity in the sedimentary stratigraphy at ca. 3000 B.P. marks a return of a relatively high-energy flood regime, presumably due to combined climatic and anthropogenic factors.

Archaeological deposits from the early Holocene, prior to 7010 B.P., were subject to high-energy Ohio River discharges; some were reworked or eroded, while others were sealed in discrete contexts. A hiatus in human occupation of the site occurred between ca. 7010 and 4315 B.P., but was followed by serial occupations throughout the late Holocene. Slow sedimentation rates have resulted in minimal vertical separation between assemblages from individual occupations in the late Holocene. As such, occupationspecific archaeological assemblages deposited after 4315 B.P. are essentially indiscernible. 


\section{Acknowledgments}

This thesis would not have been possible if not for the archaeological investigations at West Blennerhassett in 2002 and 2003; I thank the West Virginia Division of Highways and the Federal Highways Administration for funding the investigations.

My gratitude is also extended to members of the Cultural Resources Section of Michael Baker Jr., Inc. (Baker) who made this research possible, including those who organized and oversaw archaeological investigations at the site as well as the archaeological field technicians who performed the day-to-day tasks of excavating and documenting the site. Special thanks to my friends and colleagues at Baker, Denise L. Grantz-Bastianini, William (Bill) C. Johnson, and Stephen Hinks for their support and encouragement throughout the archaeological investigations and during my academic pursuit. Thanks also to Mark Fetch (a.k.a. Sparky) at Baker for creating CADD maps and profiles that are used in this thesis.

I would like to thank my graduate research committee chair, Dr. J. Steven Kite, for his encouragement and guidance and for reviewing several early drafts of this thesis. Thanks also to the other members of my graduate research committee, Dr. Timothy Warner and Dr. James Thompson, for their support and for reviewing this thesis.

Lastly, I thank my family for their support and encouragement. My wife, Valerie McCormack, and our children, Greta and Stella, have been a primary source of inspiration. 


\section{Table of Contents}

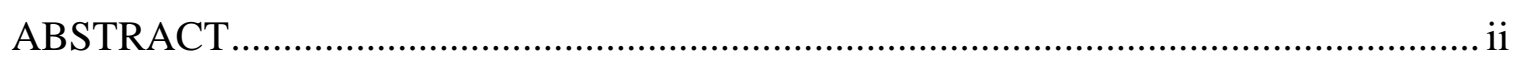

Acknowledgments............................................................................................... iii

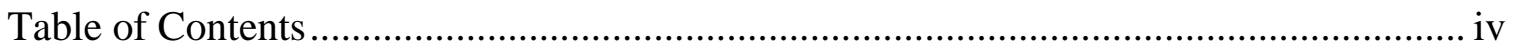

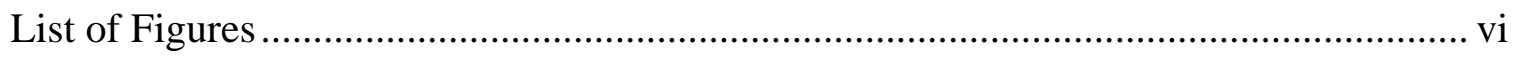

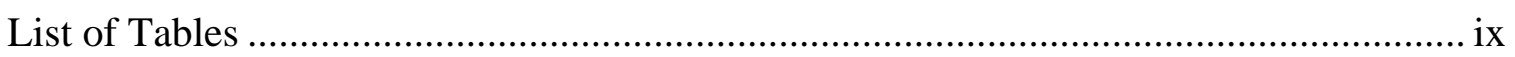

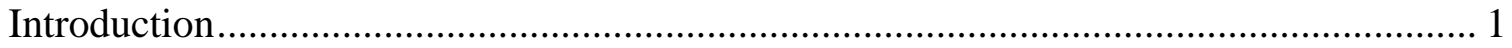

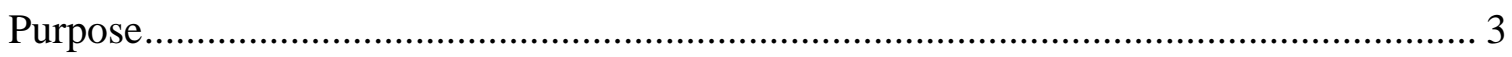

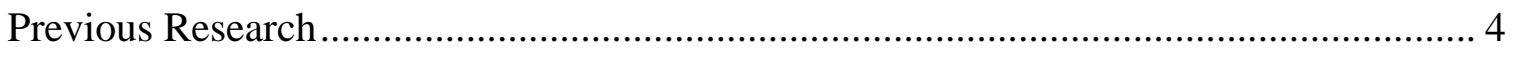

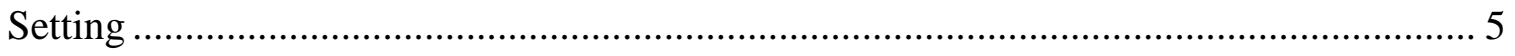

Blennerhassett Island Geomorphology …………………......................................... 7

Blennerhassett Island Late Holocene Geomorphic History ........................................... 10

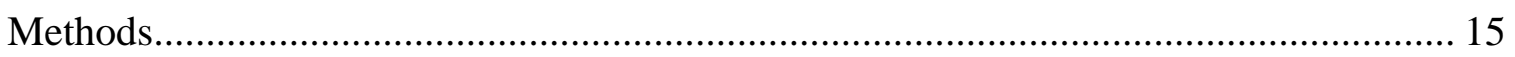

Overview of Archaeological Excavations and Field Techniques ................................... 15

Grid Elevation Conversions and Depth References...................................................... 26

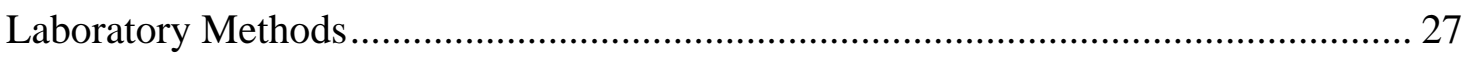

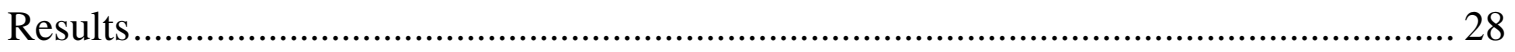

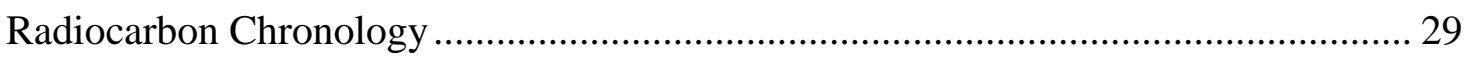

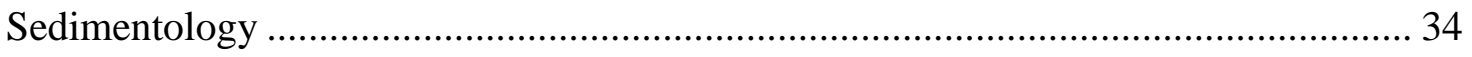

Sedimentary Unit 1 (SU 1) ............................................................................ 37

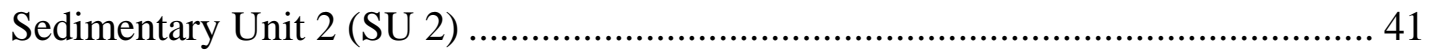

Sedimentary Unit 3 (SU 3) ............................................................................ 42

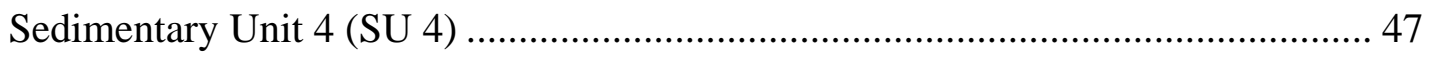




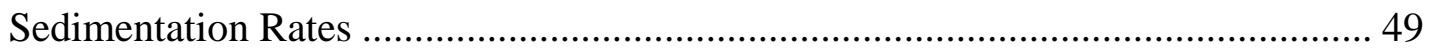

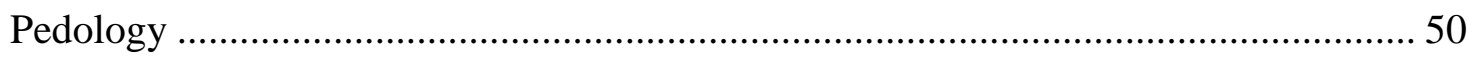

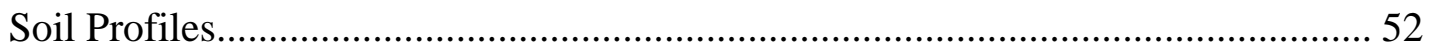

Cultural Stratigraphy and Occupational Components ....................................................6 60

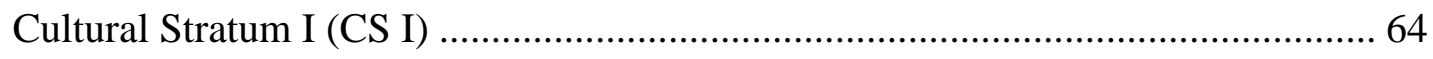

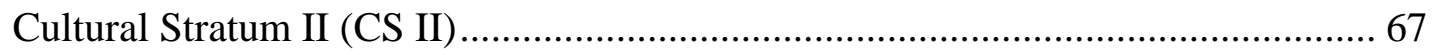

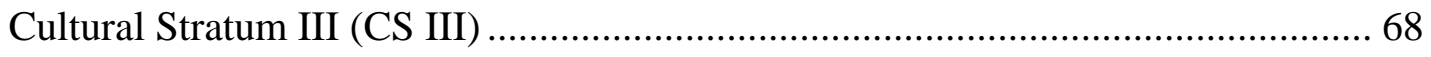

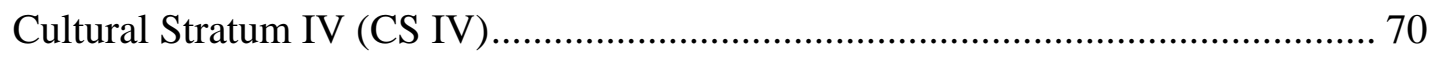

Occupational Components 1 and 2 (OC 1 and OC 2)............................................ 73

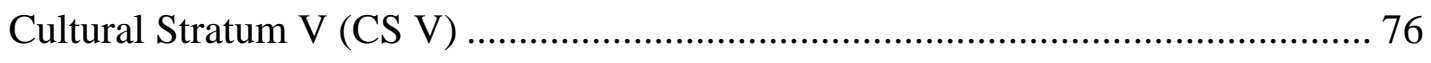

Occupational Component 3 (OC 3) ..................................................................... 78

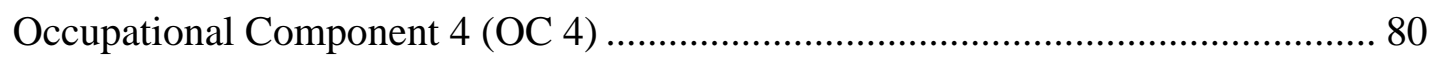

Cultural Stratum VI (CS VI).......................................................................... 85

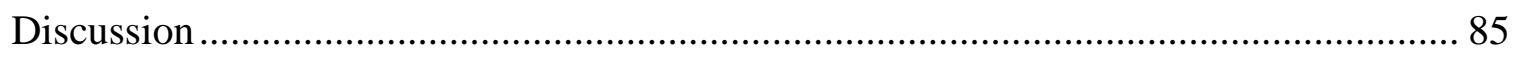

Deposition Environments and Holocene Landform Evolution....................................... 87

Natural Site Formation Processes ............................................................................ 92

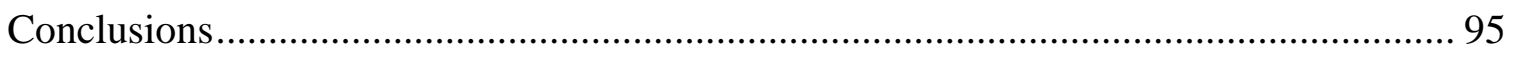

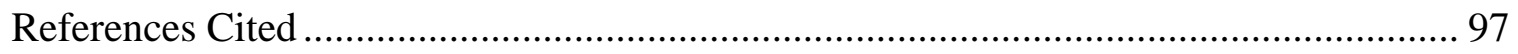

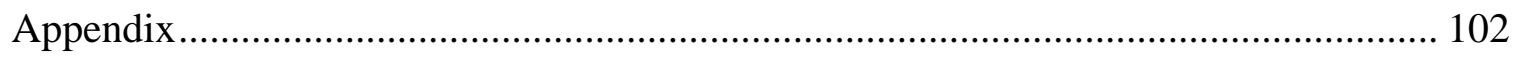




\section{List of Figures}

Figure 1: Location of Blennerhassett Island and the West Blennerhassett site on the Parkersburg, WV and Little Hocking, OH-WV 7.5' quadrangles .................................... 3

Figure 2: Hemmings's Figure 2-2 showing the distribution of T1, T2, and ancestral island

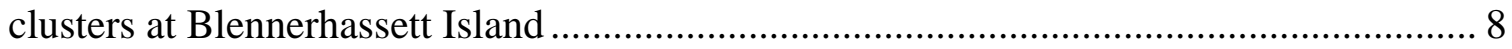

Figure 3: Blennerhassett Island in 1886 shown as three separate islands....................... 13

Figure 4: Blennerhassett Island, circa 1902, shown as two landmasses.......................... 14

Figure 5: Mosaic of Ohio River Board of Engineers 1911-1914 charts showing

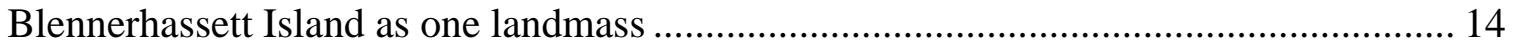

Figure 6: Mosaic of 1934 U.S. Army Corps of Engineers Ohio River Aerial Survey photos showing Blennerhassett Island as one landmass .............................................. 15

Figure 7: West Blennerhassett site map showing site grid and location of shovel test probes (STP) and Geoprobe® test sites .

Figure 8: Map of the West Blennerhassett site showing the location of Phase II block excavations, Phase I deep tests, and Phase III excavations Area 1 and Pier 5................ 19

Figure 9: Southwest-facing view of Block 5 excavated to $120 \mathrm{~cm}$............................. 20

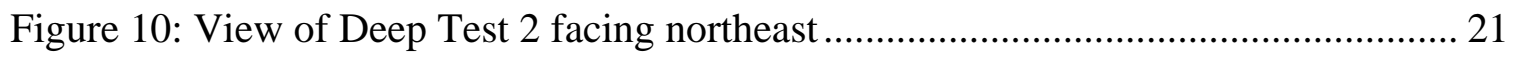

Figure 11: View of Deep Test 1 near the base of excavation ....................................... 22

Figure 12: Map of the West Blennerhassett site showing the locations of manual excavation units in Deep Test 1, Deep Test 2, Area 1 and Pier 5.................................. 23

Figure 13: West Blennerhassett radiocarbon date distribution chart .............................. 33

Figure 14: Generalized profile of Deep Test 1, Deep Test 2, and Pier 5 facing downriver and showing Sedimentary Units 1 through 4, Sediment Sample Columns 1 through 5, and

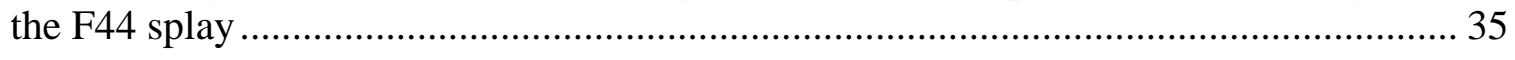

Figure 15: Column 1 sedimentary units, granulometry, and mean grain size. ................ 39

Figure 16: Column 2 sedimentary units, granulometry, and mean grain size ................. 40

Figure 17: Column 3 sedimentary units, granulometry, and mean grain size ................ 43 
Figure 18: Column 4 sedimentary units, granulometry, and mean grain size

Figure 19: Column 5 sedimentary units, granulometry, and mean grain size ................ 45

Figure 20: Profile of the south wall of Deep Test 1 between 420-480 cm depth

Figure 21: East wall profile of the E500 Trench in Pier 5 showing relatively unaltered alluvial beds

Figure 22: NRCS Web Soil Survey image of the site area showing soil series designations and the approximate location of Pier 5

Figure 23: Map of the northern portion of West Blennerhassett, showing the distribution of soil horizons in the upper profiles of Deep Test 1, Deep Test 2, Area 1, and Pier 5... 53

Figure 24: Generalized profile of Deep Test 1, Deep Test 2, and Pier 5 facing downriver and showing soil horizons. 54

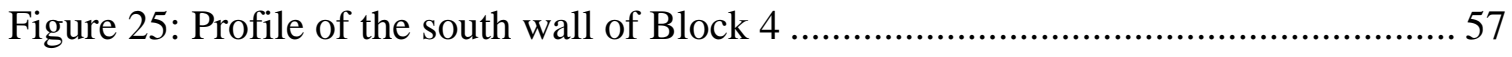

Figure 26: North wall profile of Phase II Block 1 excavation....................................... 58

Figure 27: Profile of test unit N425 E522 in Deep Test 1 between roughly 230 and 290 cm depth facing south 60

Figure 28: Generalized profile of Deep Test 1, Deep Test 2, and Pier 5 facing downriver and showing Cultural Strata I through VI and Occupational Components 1 through $4 . . .63$

Figure 29: View of Area 1 and Pier 5 excavated to near the top of CS II, facing slightly right of downriver

Figure 30: View of Pier 5 excavated to near the top of CS IV, facing downriver.

Figure 31: View of Pier 5 excavated mid-way through CS IV, at the levels of OC 2 and OC 2A, facing slightly right of downriver. 66

Figure 32: View of Pier 5 excavated to CS V, facing downriver ..... 66

Figure 33: Feature 64 shown partially excavated in plan view and in cross-section profile.....

Figure 34: Map of Deep Test 1, Deep Test 2, and the Pier 5 excavation showing the distribution of archaeological test units in CS IV 
Figure 35: Map of Deep Test 1 and the Pier 5 excavation showing the distribution of cultural features in OC 1 and OC 2/2A........................................................................ 72

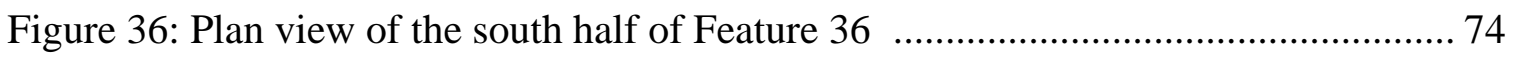

Figure 37: Profile of the west wall of 1 x 1 m unit N435 E505 showing OC 2A............. 75

Figure 38: Map of Deep Test 1 and the Pier 5 excavation showing the distribution of

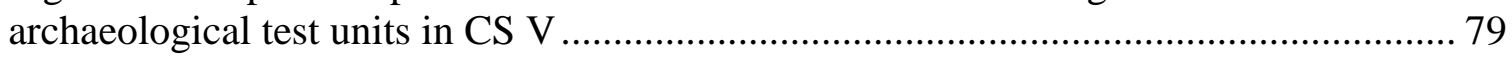

Figure 39: Plan view of portion of OC 4 showing Feature 288......................................... 81

Figure 40: Plan view of portion of OC 4 showing the west half of Feature 276.............. 82

Figure 41: Profile of OC 4 along grid E495 between grid N439 and N441 ..................... 83

Figure 42: View of Pier 5 facing north showing archaeological test units in OC 4......... 84 


\section{List of Tables}

Table 1: Summary of alluvial stratigraphy identified in the Pier 5 excavation during the U.S. Route 50 Blennerhassett Bridge geotechnical study................................................. 11

Table 2: West Blennerhassett Radiocarbon Dates.............................................................. 31

Table 3: West Blennerhassett sedimentary unit correlation table...................................... 38

Table 4: Sedimentation rates at West Blennerhassett....................................................... 50

Table 5: Soil horizons in Deep Test 1........................................................................ 55

Table 6: Soil horizons in Deep Test 2.................................................................... 55

Table 7: Soil horizons at N440.00 E470.00 in Block 1/Area 1....................................... 56

Table 8: Soil horizons at N439.37 E506.30 along the south wall of Pier 5....................... 56

Table 9: Cultural strata in Deep Test 1, Deep Test 2, Area 1, and Pier 5.......................... 61

Table 10: Occupational components at West Blennerhassett............................................. 62 


\section{Introduction}

Stratified archaeological sites typically develop in depositional settings where human occupation occurs between depositional episodes. Such stratified archaeological sites, in proper context, can serve as repositories of information on behavioral patterns over time. The context of archaeological deposits in depositional settings is directly affected by sedimentation and soil formation. In addition, sediments and soils serve as proxy indicators of depositional environments; in stratified alluvial settings sediments and soils have potential to reveal sequences of landform development. This thesis presents a geomorphic history of the West Blennerhassett site (46WD83-A), a deeply stratified archaeological site in Wood County, West Virginia, which is used to correlate archaeological components with stages in the depositional environment. This thesis also presents an assessment of natural site formation processes related to sedimentation and soil formation as they pertain to stratified archaeological deposits at West Blennerhassett.

Natural site formation processes, also known as natural transformations and noncultural transformations, are the noncultural mechanisms that act to preserve, alter, or destroy archaeological sites (Schiffer 1983, 1987; Stein 2001; Waters 1992).

Understanding natural site formation processes is integral to inferring behavioral patterns from archaeological sites (Schiffer 1983; Waters 1992:11) and sedimentation and soil formation (pedogenesis) are among the most widely recognized natural site formation processes in alluvial settings (Ferring 1986, 1992; Waters 1992).

Waters (1992:15) defines the matrix of an archaeological site as "the physical medium that surrounds all artifacts, features, and ecofacts" and states that the matrix "is composed of two major components: sediments and soils”. In as much as sediments and 
soils house archaeological deposits, they also serve as proxy records of depositional environments that correspond with archaeological occupations at a site over time (Dincauze 2000; Ferring 2001; Hassan 1978; Holliday 2001, 2004; Rapp and Hill 2006; Waters 1992). This relationship provides the opportunity to correlate occupational episodes with stages in the geomorphic history at a given site and to place past human activities into a broader environmental context.

The West Blennerhassett archaeological site is located on Blennerhassett Island, an Ohio River island, in Wood County, West Virginia (Figure 1). Archaeological excavations were conducted at the site in 2002 and 2003 by the Cultural Resources Section of Michael Baker Jr., Inc. as part of the environmental studies for the Blennerhassett Bridge Project on U.S. Route 50 (a.k.a. Appalachian Corridor D) for the West Virginia Division of Highways and the Federal Highways Administration (Grantz et al. 2002; Johnson et al. 2003; Robinson et al. 2008). These investigations revealed stratified archaeological deposits extending to a minimum of $5 \mathrm{~m}$ and covering much of the span of human occupation in the Upper Ohio River basin, from the late Early Archaic (ca. 8660 B.P.) through the present (Grantz et al. 2002; Johnson et al. 2003; Robinson et al. 2008). Archaeological data recovered from West Blennerhassett have the potential to yield information regarding human behavioral patterns over time in the Upper Ohio River basin. In order to glean behavioral inferences from these data, it is imperative that the sedimentary and pedogenic matrix from which the archaeological data was recovered is fully understood. It is also necessary that the natural site formation processes that have affected the West Blennerhassett archaeological data be fully considered to make inferences and draw conclusions from the data. 
This thesis presents a history of landform evolution and sedimentary sequences at West Blennerhassett. In addition, site-specific effects of sedimentation and pedogenesis on archaeological deposits are inferred and presented.

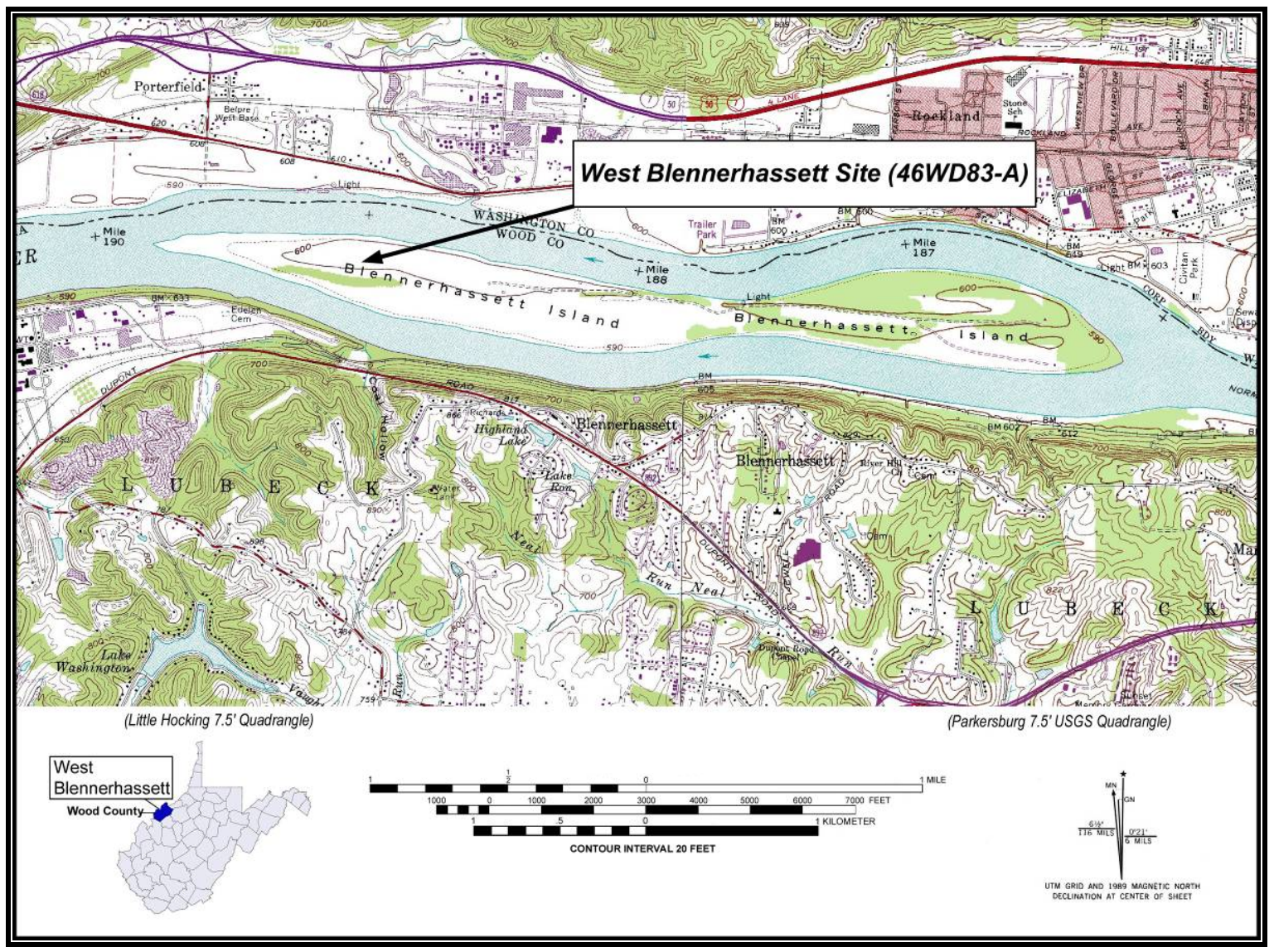

Figure 1: Location of Blennerhassett Island and the West Blennerhassett site on the Parkersburg, WV and Little Hocking, OH-WV 7.5' quadrangles (U.S. Geological Survey 1969 [photorevised 1989]; 1961 [photorevised 1988]). Adapted from Robinson et al. (2008).

\section{Purpose}

The primary purpose of this research is to provide a geomorphic, sedimentary, and pedogenic context for archaeological deposits that spans approximately 8660 years of documented human occupation at West Blennerhassett. Such a context is critical to understanding natural site formation processes at the site as well as along low terraces and floodplain surfaces throughout the upper Ohio River Valley. 
Additionally, the placement of cultural components in their original geomorphic context is critical to understanding site selection processes and, at a larger scale, human settlement patterns over time. A secondary purpose of this research is to provide a context of the near-channel sedimentary environment during human occupations at the site. Such a context will enable others to interpret West Blennerhassett archaeology in terms of site selection variables, which, in turn, can be used to infer behavioral patterns of past cultures.

\section{Previous Research}

Knowledge of the geologic history and Quaternary stratigraphy of the upper Ohio River valley are critical to this research. Theses by Rogers (1990) and Simard (1989) and an abstract by Kite et al. (2006) serve as the primary sources of this knowledge for the purpose of this thesis.

Several reports on archaeological and geological investigations at Blennerhassett Island, including reports from investigations at West Blennerhassett, contain information that is relevant to the proposed research. E. Thomas Hemmings (1977) provided a thorough summary of the late Holocene geomorphic evolution of Blennerhassett Island; the "Blennerhassett Island Late Holocene Geomorphic History" in the Setting section of this thesis is based largely on Hemmings's (1977) summary. A report of archaeological investigations at West Blennerhassett prepared by Fowler and Graybill (1984) provides insight into archaeological phenomena at the site, though this reference is of somewhat limited value with regard to geoarchaeology at West Blennerhassett. Reports on the 2002 and 2003 archaeological investigations at West Blennerhassett by Grantz et al. (2002), Johnson et al. (2003), and Robinson et al. (2008) are cited throughout this thesis. Also, 
the final report for the U.S. Route 50 Blennerhassett Bridge geotechnical study by H.C. Nutting Company (2004) provides relevant information regarding the depth of alluvial sediments at West Blennerhassett.

The body of references pertaining to natural site formation processes and geoarchaeology in alluvial settings is robust. Among such references consulted for this

research, those by Ferring $(1986,1992)$ and Waters (1992) are primary in the Discussion section of this thesis.

Reports of geomorphologic investigations at the Leetsdale archaeological site (36AL480), a deeply stratified Ohio River valley site in Pennsylvania, by Schuldenrein et al. (2002), and Vento et al. (2002) provide relevant comparative data on alluvial sedimentology in the upper Ohio River Basin. Likewise, pertinent data regarding alluvial sedimentology in the Delaware River valley in Pennsylvania is provided by Schuldenrein (2003). Results from this study are compared to results presented by Schuldenrein et al. (2002), Vento et al. (2002), and Schuldenrein (2003) in the Discussion section of this thesis.

\section{Setting}

The West Blennerhassett archaeological site is located on Blennerhassett Island in Wood County, West Virginia. Blennerhassett Island is situated in a reach of the Ohio River that flows generally from east to west (Figure 1). The normal pool elevation of the Ohio River at Blennerhassett Island is maintained at $177.39 \mathrm{~m}$ (582 ft) above mean sea level (AMSL) by the Belleville Dam at river km 328.15 (mile 203.9). The head of the island begins at river km 299.7 (mile 186.2, as measured from Pittsburgh), 2.40 km (1.49 mi) downstream from the confluence of the Little Kanawha River with the Ohio 
River. The island is $\sim 5.48 \mathrm{~km}$ (3.41 mi) long. The West Blennerhassett site is located roughly at river $\mathrm{km} 304$ (mile 189). The surface of the site occurs between 181 and 183 m ( 595 and $600 \mathrm{ft})$ AMSL; archaeological deposits extend to a minimum of $5 \mathrm{~m}(16 \mathrm{ft})$ below ground surface.

The project area, as well as the entire length of the Upper Ohio River upstream from Blennerhassett Island, is in the Unglaciated Allegheny Plateau section of the Appalachian Plateaus physiographic province (Fenneman 1938). Though the upper Ohio River Valley remained unglaciated throughout the Pleistocene, approximately 25 percent of the Ohio River basin was intermittently glaciated (Kite et al. 2006; Rogers 1990). Sediment supply to the Ohio River was greatly increased during periods when glaciers occupied the basin; this increase in sediment caused the river to aggrade and braid its channel (Kite et al. 2006; Rogers 1990). After the final retreat of glacial ice from the basin, the Ohio River transformed from an aggrading, braided channel to an incising, meandering channel in response to a decrease in sediment supply (Kite et al. 2006; Rogers 1990).

The effects of intermittent episodes of aggradation and incision in response to glacial advance and retreat, and the subsequent shift in channel morphology are reflected in the geomorphology, stratigraphy, and sedimentology of fluvial landforms of the upper Ohio River Valley (Kite et al. 2006; Rogers 1990; Simard 1989). Terraces, floodplains, and mid-channel islands are common fluvial landforms throughout the upper Ohio River Valley and are cored with coarse-grained outwash deposited during episodes of glaciation or subsequently reworked outwash (Rogers 1990; Simard 1989). These landforms are typically capped by fine-grained Holocene alluvium, which tends to be thinner on higher, 
and presumably older, fluvial landforms, and thicker on lower landforms (Rogers 1990; Simard 1989).

\section{Blennerhassett Island Geomorphology}

In a study of the lower terraces and floodplains of the upper Ohio River Valley, Simard (1989) identified Blennerhassett Island as a Holocene floodplain surface designated as S2. The S2 surface is the highest, and apparently the oldest, of three floodplain surfaces that Simard identified; the lower floodplain surfaces were identified as S0 and S1. Topographically, the next highest alluvial surface that Simard identified is S3, which she interpreted as a late Wisconsinan terrace. The recovery of temporally diagnostic artifacts representative of late Early Archaic period manifestations, as well as

several ${ }^{14} \mathrm{C}$ age determinations from $>8000$ B.P. at approximately $5 \mathrm{~m}$ below ground surface (Robinson et al. 2008; Robinson, this thesis) attest to a Holocene depositional timeframe for surficial deposits at West Blennerhassett.

In a report of investigations at the Neale’s Landing archaeological site (46WD39) on Blennerhassett Island, Hemmings (1977) concluded that Blennerhassett Island is composed of two terraces, T1 and T2 (Figure 2). According to Hemmings, T2 consists of alluvium that grades upward from coarse sands and gravels "to a thick section of massive bedded silts” (1977:2-3). Hemmings deduced that most of the T2 alluvium exposed above the 1977 pool elevation (178.6 m [586 ft] AMSL) was “deposited in the last few thousand years” (1977:2-4). Hemmings stated that the "T1 alluvium is composed of laminated silts and clayey silts” (1977:2-3) and was “deposited largely in the last two centuries” (1977:2-4). Hemmings further concluded that the extent of the terraces at Blennerhassett Island could be mapped using topographic contours and noted 
approximate maximum elevations of $181.4 \mathrm{~m}$ (595 ft) and $184.4 \mathrm{~m}$ (605 ft) AMSL for T1 and T2, respectively (Figure 2).

Robert F. Fonner, a geologist with the West Virginia Geological and Economic Survey, drew slightly different conclusions about the alluvial stratigraphy at Blennerhassett Island as a result of a Corridor D-related study (Fowler and Graybill 1984). Fonner (1984) identified four "soils”, T1 through T4 from youngest to oldest, respectively, at Blennerhassett Island. Fonner mapped T1, T2, and T3 at the surface of Blennerhassett Island, and assigned T4 to sediments buried below several meters of T1, T2, and T3 alluvium at the island. Fonner's T1 through T4 are somewhat misleading: they are not specifically ascribed to terraces, as is the convention, and Fonner refers to T1

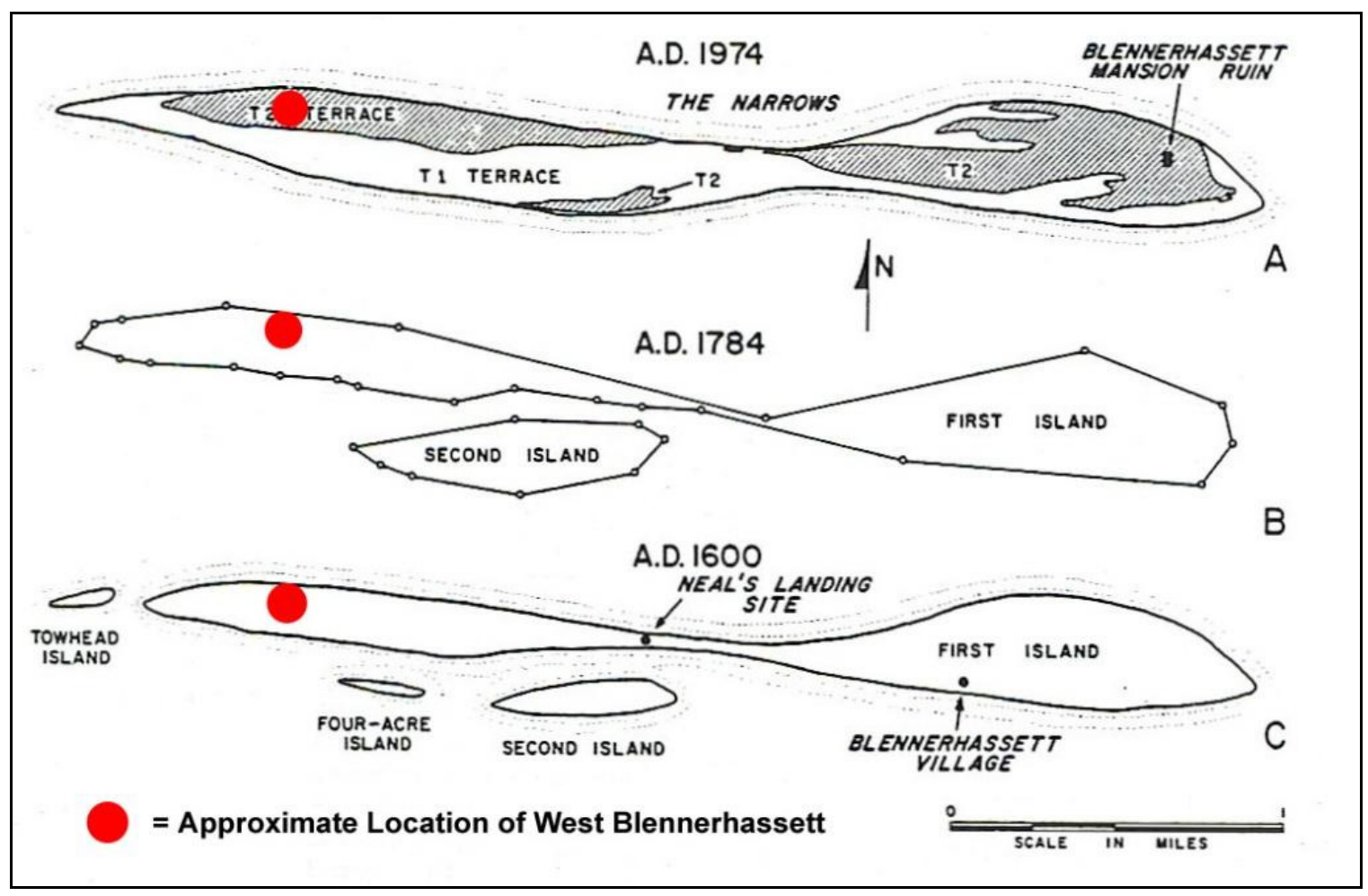

Figure 2: Hemmings's (1977) Figure 2-2 showing the distribution of T1 and T2 (A) and ancestral island clusters (B and C) at Blennerhassett Island. Modified from Hemmings (1977). 
through T4 as "soils" though he was apparently referring to alluvial sediments rather than genetic soils or weathered sediments. Nonetheless, Fonner’s T1 generally coincides with Hemmings's T1, and Fonner's T2 and T3 generally coincide with Hemmings's T2.

The thickness of fine-grained Holocene alluvium (sand, silt, and clay), and depth to coarse-grained outwash or reworked outwash (gravels) at West Blennerhassett was determined from two Corridor D-related studies: (1) archaeological Geoprobe ${ }^{\circledR}$ testing, conducted as part of the 2002 Phase I archaeological survey, and (2) a geotechnical study associated with the Blennerhassett Bridge. Subsurface probing at West Blennerhassett consisted of the recovery and analysis of Geoprobe ${ }^{\circledR}$ data. Geoprobe ${ }^{\circledR}$ testing was conducted using a truck-mounted rig to recover $7.6 \mathrm{~cm}$ (3.0 in) diameter cores from 16 sample locations spaced at intervals along parallel, north-south-trending transects (Grantz et al. 2002; Robinson et al. 2008). Gravels were encountered at $11.4 \mathrm{~m}$ (37.6 ft), $10.9 \mathrm{~m}$ (36.0 ft), and $10.7 \mathrm{~m}$ (35.3 ft) depth in the three deepest probe locations: numbers 1, 4, and 7, respectively. Sand and sandy loam sediments are recorded above gravels,

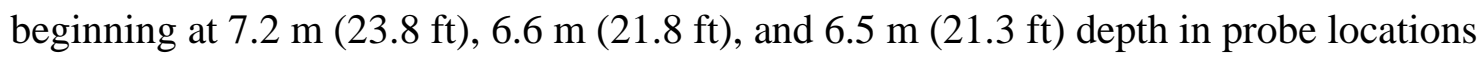
1,4 , and 7 , respectively. The depth to sand and sandy loam sediments in the remaining 13 probe locations ranged from $2.3 \mathrm{~m}(7.6 \mathrm{ft})$ to $>4.4 \mathrm{~m}(14.5 \mathrm{ft})$; all of the remaining 13 probe attempts were terminated prior to encountering gravels.

In the final report of the geotechnical study, H. C. Nutting Company (2004) provide descriptions for nine borings, designated consecutively as CB-07 through CB-15, associated with three bridge piers located on Blennerhassett Island: Piers 5, 6, and 7. Geotechnical borings in unconsolidated sediments were made using a 5.1 cm (2 in)

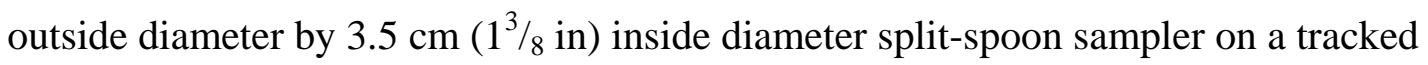


machine (H.C. Nutting Company 2004). H. C. Nutting Company report similar conditions in each of the nine borings: "Fine-grained alluvial deposits underlain by coarse granular alluvial deposits overlay bedrock, which was consistently encountered between 535 thru $538 \mathrm{ft}$ ” (2004:7). Of the three Corridor D bridge piers designed for placement across Blennerhassett Island, Pier 5 was located within the boundary of the West Blennerhassett archeological site as discussed herein. The three borings associated with Pier 5 (CB-07, CB-08, and CB-09) originated within the Pier 5 archaeological excavation and were conducted concurrently with archaeological excavations during September 2003. The top elevation of each of CB-07, CB-08, and CB-09, as reported by H. C. Nutting Company (2004), was established after removal of $\sim 2.5 \mathrm{~m}(8.2 \mathrm{ft})$ of sediment as part of the Pier 5 archaeological excavation. Unconsolidated sediments in each of CB-07, CB-08, and CB-09 were identified, from top to bottom, as lean clay, silty sand, sand, and sand and gravel (Table 1) (H. C. Nutting Company 2004). The thickness of fine-grained alluvium from the pre-Pier 5 excavation ground surface at each of CB-07, CB-08, and CB-09 is estimated, by adding $2.5 \mathrm{~m}$ to the thickness of fine-grained alluvium at the respective boring locations (Table 1), to have ranged between 13.2 and $14.6 \mathrm{~m}$ (43.3 and $47.9 \mathrm{ft}$ ). Similarly, the depth to bedrock at the three boring locations is estimated to have ranged between 18.0 and $18.6 \mathrm{~m}$ (59.1 and $61.0 \mathrm{ft})$ prior to the archaeological excavations at Pier 5.

\section{Blennerhassett Island Late Holocene Geomorphic History}

Early accounts indicate that Blennerhassett Island has evolved from a cluster of smaller islands, known variously as First Island, Second Island, Four-Acre Island, and Towhead Island, to its current form as a single landmass. Hemmings (1977) provides a 
Table 1: Summary of alluvial stratigraphy identified in the Pier 5 excavation during the U.S. Route 50 Blennerhassett Bridge geotechnical study. Adapted from H.C. Nutting Company (2004).

\begin{tabular}{|c|c|c|c|c|c|c|c|c|}
\hline $\begin{array}{l}\text { Geotechnical } \\
\text { Boring No. }\end{array}$ & $\begin{array}{l}\text { 〜Grid } \\
\text { Location }\end{array}$ & $\begin{array}{l}\text { Top of } \\
\text { Boring } \\
(\sim \mathbf{m} \\
\text { AMSL })^{a}\end{array}$ & $\begin{array}{l}\text { Bottom } \\
\text { of } \\
\text { Lean } \\
\text { Clay } \\
\text { (m } \\
\text { AMSL) }\end{array}$ & $\begin{array}{l}\text { Bottom } \\
\text { of } \\
\text { Silty } \\
\text { Sand } \\
\text { (m } \\
\text { AMSL) }\end{array}$ & $\begin{array}{l}\text { Bottom } \\
\text { of } \\
\text { Sand } \\
\text { (m } \\
\text { AMSL) }\end{array}$ & $\begin{array}{l}\text { Bottom of Sand } \\
\text { and } \\
\text { Gravel/Top of } \\
\text { Bedrock } \\
\text { (m AMSL) }\end{array}$ & $\begin{array}{l}\text { Thickness of } \\
\text { Fine-grained } \\
\text { Alluvium (m) }{ }^{\mathrm{a}, \mathrm{b}}\end{array}$ & $\begin{array}{l}\text { Thickness of } \\
\text { Unconsolidated } \\
\text { Sediment (m) }{ }^{\mathrm{a}, \mathrm{c}}\end{array}$ \\
\hline CB-07 & $\begin{array}{l}\text { N443.00 } \\
\text { E500.30 }\end{array}$ & 179.3 & 174.7 & 171.7 & 168.6 & 163.8 & 10.7 & 15.5 \\
\hline CB-08 & $\begin{array}{l}\text { N438.75 } \\
\text { E512.20 }\end{array}$ & 179.3 & 174.8 & 170.2 & 167.2 & 163.2 & 12.1 & 16.1 \\
\hline CB-09 & $\begin{array}{l}\text { N440.25 } \\
\text { E488.90 }\end{array}$ & 179.3 & 174.4 & 171.7 & 168.6 & 163.3 & 10.7 & 16.0 \\
\hline
\end{tabular}

${ }^{\mathrm{a}}$ After removal of $\sim 2.5 \mathrm{~m}$ of sediment from the Pier 5 excavation.

${ }^{\mathrm{b}}$ Determined by subtracting the elevation at the bottom of sand from the elevation at the top of boring.

${ }^{\mathrm{c}}$ Determined by subtracting the elevation at the bottom of sand and gravel from the elevation at the top of boring. 
plausible depiction of the late prehistoric and early historic period island cluster based on early maps, historic accounts, and modern topography (Figure 2). Among the accounts referenced by Hemmings (1977: 2-1, 2-3) and attributed to Swick (1975) are descriptions of Blennerhassett Island by: “George Croghan, an Indian trader, in 1765; Thomas Hutchins, cartographer and hydrographic surveyor, in 1766; George Washington, in his capacity as land-patent claimant, in 1770; Winthrop Sargent, a traveler, in 1794; and Victor Collot, a French official, in 1796”. Also among the primary resources for Hemmings's reconstruction of the late prehistoric island cluster is a survey produced in 1784, "by John Vanderen Jun. Asst. to Saml. Hanway, Surveyor for Monongalia County” (Surveyor’s Record No. 5, Page 74, Monongalia County, as cited by Hemmings 1977: 23). Hemmings supported his depiction of the island cluster in A.D. 1600 (Figure 2 herein) by comparing it to Charles Rector's 1932 depiction of the island cluster, “as seen by Washington in 1770" (as cited by Hemmings 1977:2-3). Hemmings (1977:2-3) went on to attribute the "rapid coalescence of the island cluster in the $19^{\text {th }}$ century" to early historic period land-use practices, including the construction of a wing dam (also known as a pedestrian causeway and rock and crib dike) connecting mainland West Virginia with the head of the "main" island.

The historic period coalescence of Blennerhassett Island is further documented in a series of early maps (Figures 3-5) and a mosaic of U.S. Army Corps of Engineers (1934) aerial photographs (Figure 6). A map published by D. J. Lake and Company (1886) (Figure 3) shows the ancestral Blennerhassett Island as a cluster of three separate islands. A U.S. Geological Survey (USGS) map from 1902 (Figure 4) shows that Blennerhassett Island consisted of two separate islands in the early Twentieth Century. A 
mosaic of charts 52, 53, and 54 from the 1911-1914 Ohio River Survey (District Engineer Office 1911-1914) (Figure 5) shows the island as one landmass. A wing dam is indicated on the 1902 USGS map (Figure 4) and is shown in the 1911-1914 Ohio River Survey map where it is labeled as "Rock And Crib Dike” (Figure 5). The local Ohio River pool elevation was artificially raised to $174.4 \mathrm{~m}$ (572.2 ft) AMSL by Dam No. 19 at approximately river km 308 (mi 191.4) (Jones 1920). Dam No. 19 became operational in October 1916 (Chief of Engineers 1917) and the wing dam was apparently submerged shortly thereafter. Though a portion of the wing dam can be seen at the head of Blennerhassett Island in Figure 6, it is apparent that, for the most part, the wing dam is under water.

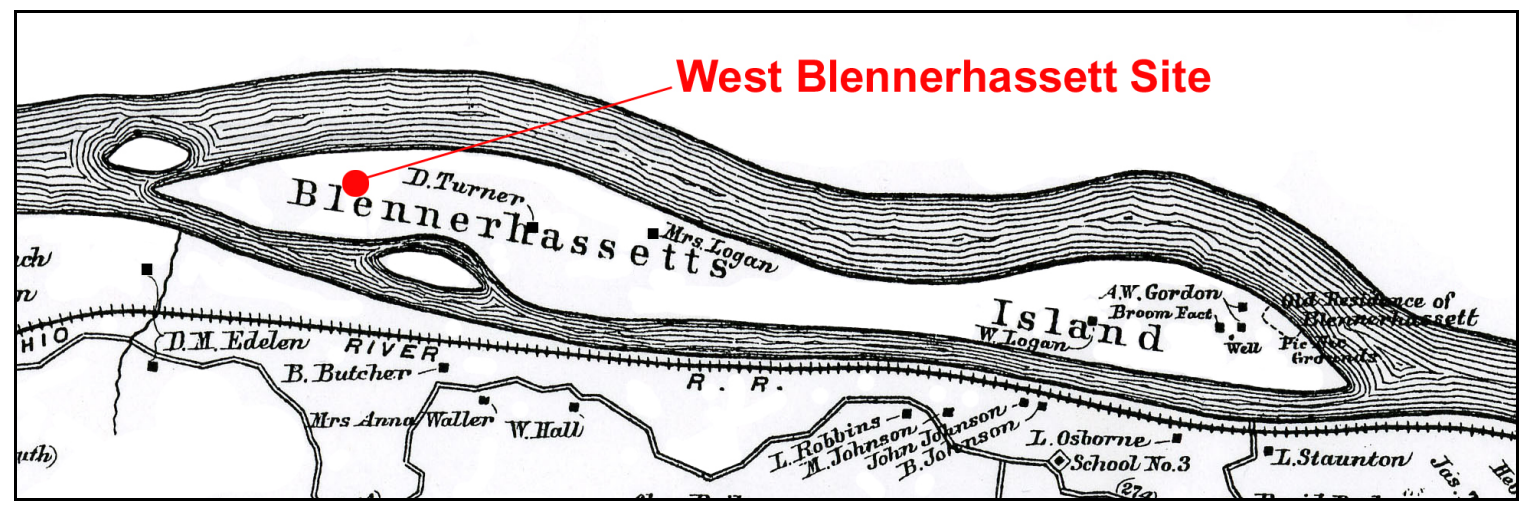

Figure 3: Blennerhassett Island in 1886 shown as three separate islands (adapted from D. J. Lake \& Company 1886:39). 


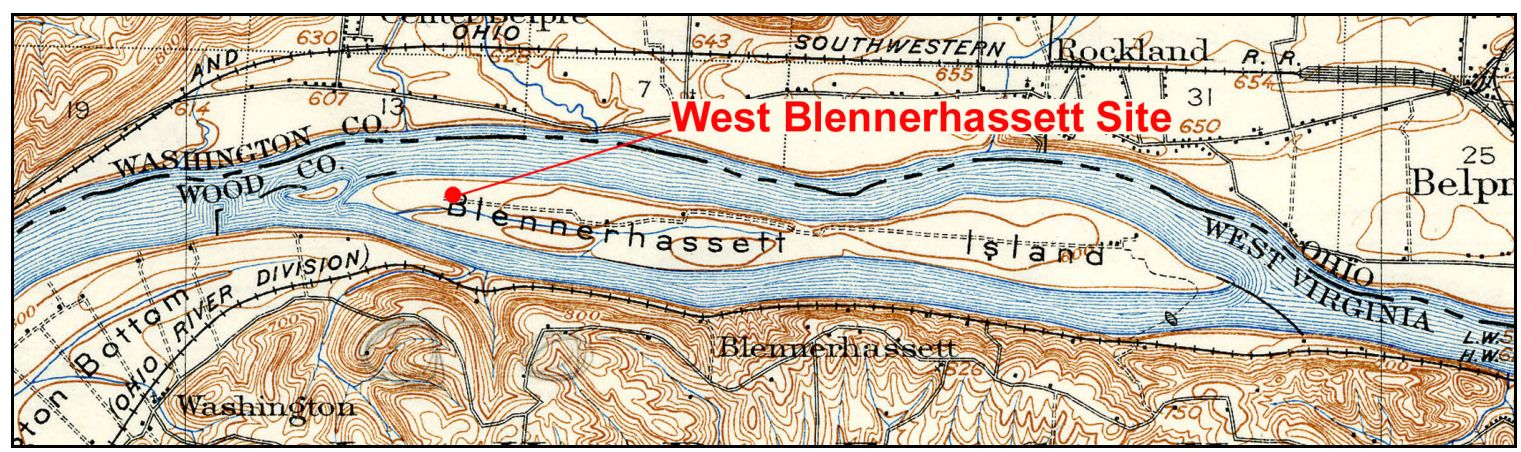

Figure 4: Blennerhassett Island, circa 1902, shown as two landmasses (from 1904 Edition U.S.G.S. Parkersburg, Ohio-W.VA. 15’ quadrangle [Surveyed 1902, Reprinted 1935]). Note the wing dam at the head (east end) of the island.

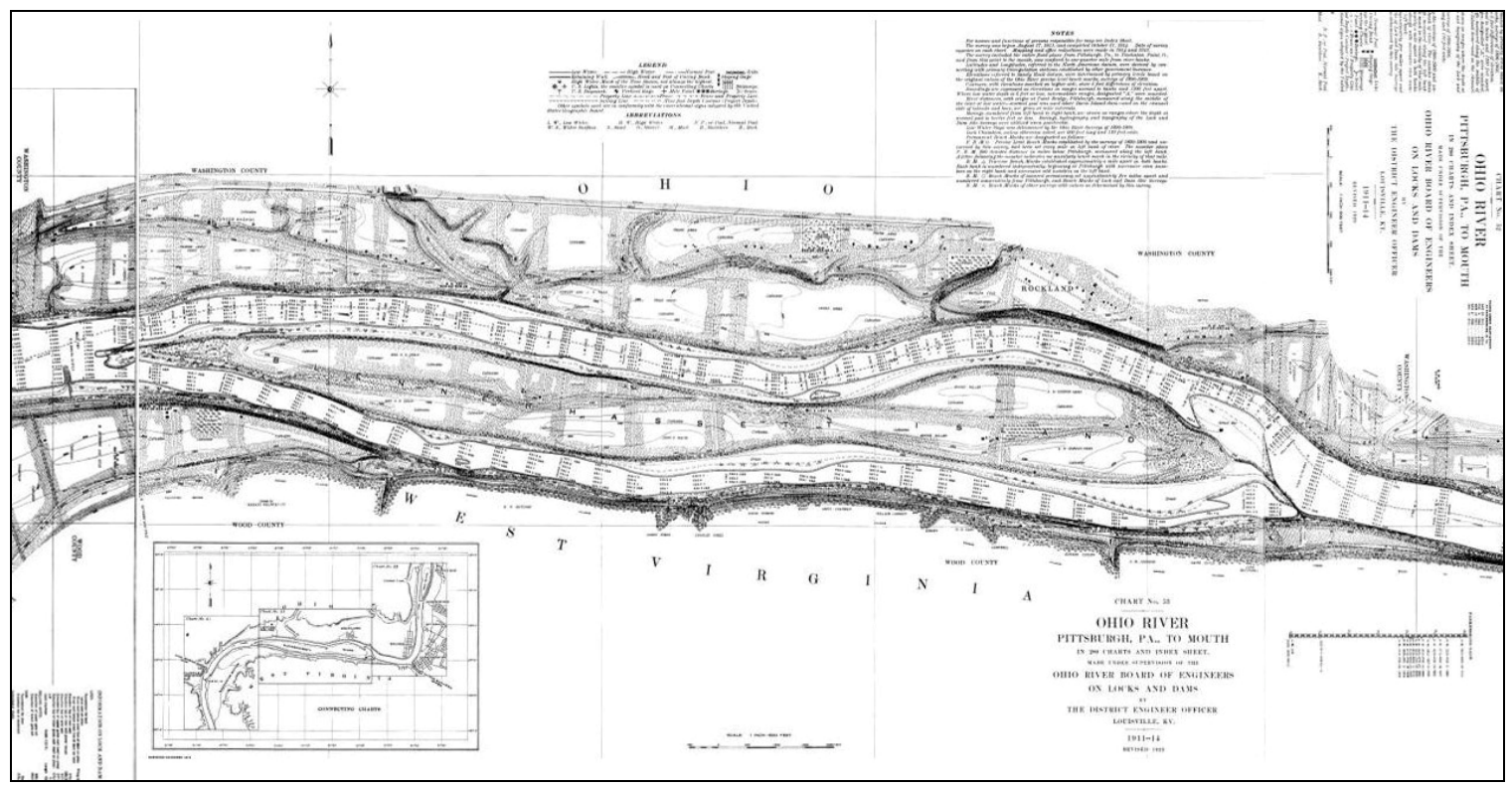

Figure 5: Mosaic of Ohio River Board of Engineers 1911-1914 charts 52-54 showing Blennerhassett Island as one landmass. Note the sand bars forming around the wing dam (shown here as "rock and crib dike") at the head (east end) of the island. 


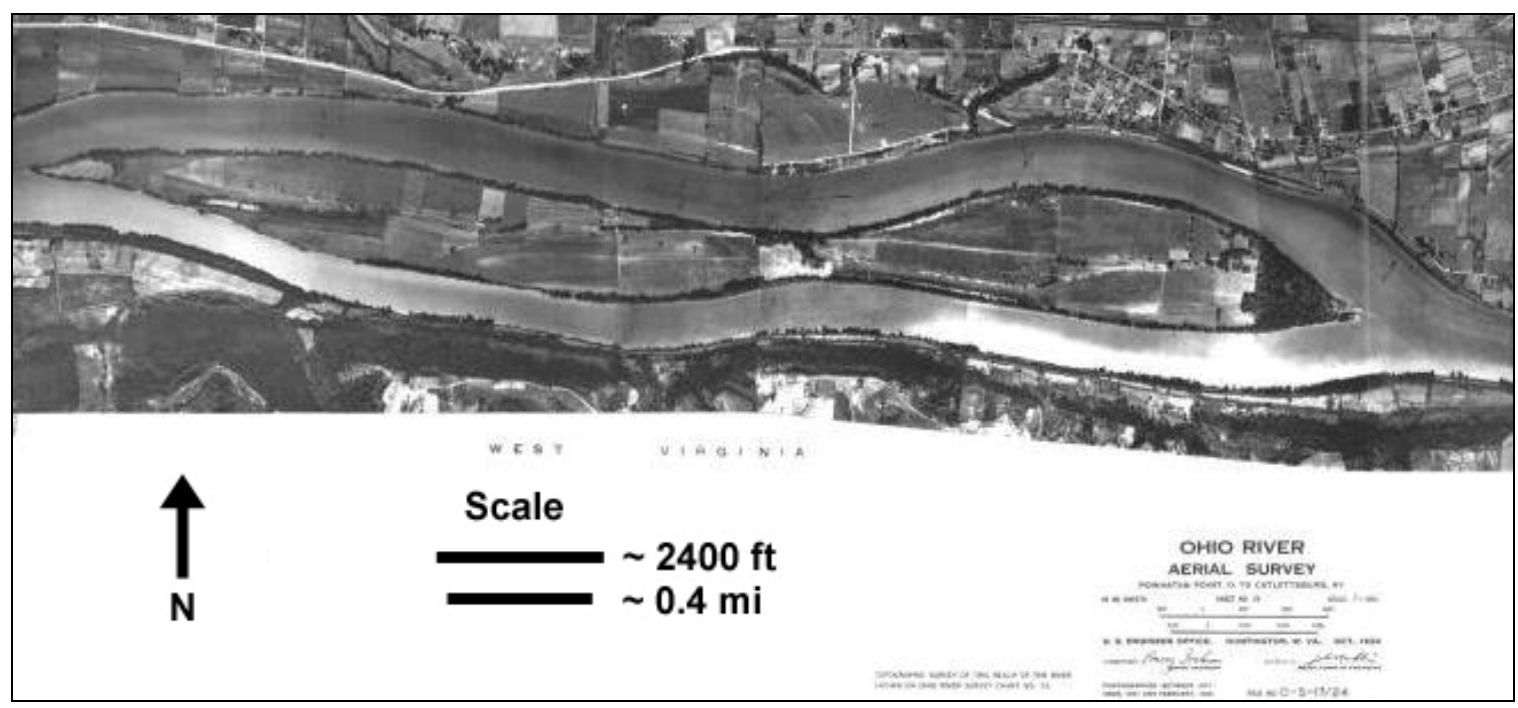

Figure 6: Mosaic of 1934 U.S. Army Corps of Engineers Ohio River Aerial Survey photos (sheets 23 and 24) showing Blennerhassett Island as one landmass. Note that the wing dam appears to be submerged.

\section{Methods}

Overview of Archaeological Excavations and Field Techniques

The West Blennerhassett site was investigated through multiple phases of excavation between June 2002 and October 2003. Phase I archaeological survey was conducted between June and July 2002. Phase II archaeological site evaluation was conducted from August through November 2002. Phase I deep testing was initiated in October 2002 and ran concurrently with Phase II site evaluation excavations until November 2002. Phase III data recovery excavations were conducted between May and October 2003. An overview of the archaeological excavations at West Blennerhassett as well as a summary of pertinent archaeological field techniques is presented in the following section. More detailed descriptions of the excavations and field techniques can be found in Grantz et al. (2002), Johnson et al. (2003), and Robinson et al. (2008).

A Cartesian grid was established across the study area at the onset of Phase I archeological survey and was used throughout all subsequent phases of archaeological 
investigation. Grid north was established at three degrees east of magnetic north so that grid north-south was oriented parallel to the proposed U.S. Route 50 Blennerhassett Bridge alignment. A primary grid datum was established in the north-central portion of the site, at the U.S. Rt. 50 project station 2219+00, and was assigned grid coordinates N500 E500. An arbitrary grid elevation of $100.00 \mathrm{~m}$, equal to $181.57 \mathrm{~m}$ AMSL, was established as a datum at the ground surface at grid N500 E500. All excavation locations, sample proveniences, and other spatial data from the Phase I through Phase III archaeological investigations were recorded, using a Nikon DTM 330 total station, with reference to the site grid in three dimensions: by northing, easting, and grid elevation (e.g. N500 E500, elev. 100.00 m). All manual excavation units, shovel test probes (STPs), sample units, and test units, were designated by the grid coordinates at their southwest corners.

The system of stratigraphic nomenclature used during all phases of archaeological field work was the Field Designation system, a variation of the Harris Matrix (Harris 1989). According to the Field Designation system, all sedimentary strata, soil horizons, and cultural features were assigned Field Designation numbers upon identification. Field Designation numbers were assigned as the letter "F" preceding an Arabic numeral (e.g. F3). Field Designations were assigned to individual stratigraphic entities sequentially as they were encountered, beginning with Field Designation F3; F1 and F2 were assigned to the field notes and archaeological site, respectively, by convention.

Phase I archeological survey consisted of the manual excavation of 101 STPs and the mechanical excavation of 16 Geoprobe ${ }^{\circledR}$ test holes across the study area (Figure 7). 


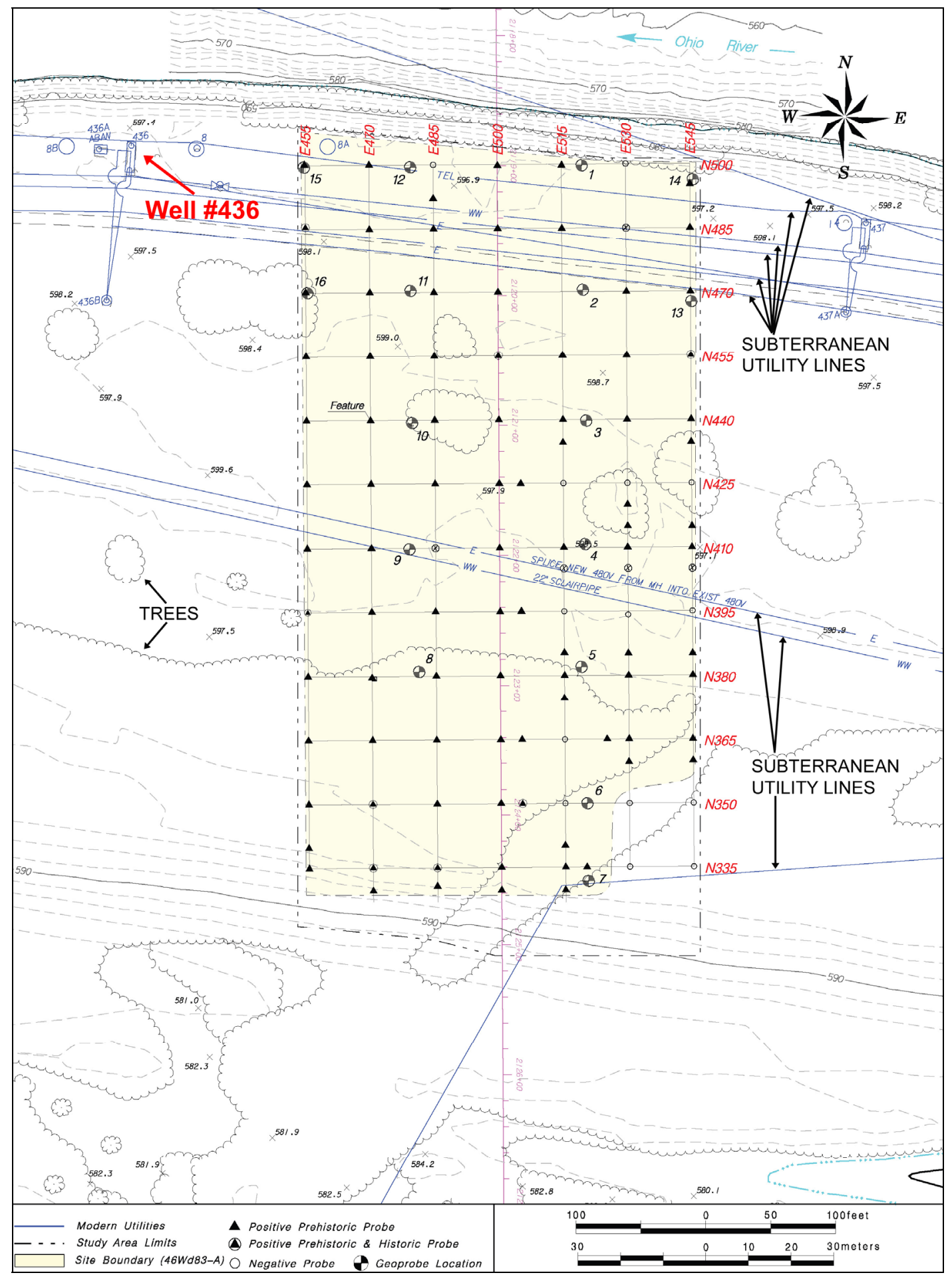

Figure 7: West Blennerhassett site map showing site grid and location of shovel test probes (STP) and Geoprobe ${ }^{\circledR}$ test sites. Note DuPont well \#436 in the upper left hand corner. Adapted from Robinson et al. (2008). 
STPs, located at horizontal intervals ranging between 5 and $15 \mathrm{~m}$, were roughly $50 \mathrm{~cm}$ diameter by $100 \mathrm{~cm}$ deep and were excavated by arbitrary $10 \mathrm{~cm}$ levels within natural strata. All excavated sediments from STPs were sifted through $0.64 \mathrm{~cm}(1 / 4$ in) hardware cloth to facilitate artifact recovery. Geoprobe ${ }^{\circledR}$ samples were recovered to various depths between 2.30 and $11.35 \mathrm{~m}$.

Phase II testing was conducted between August and November 2002 and consisted of the manual excavation of $591 \mathrm{~m} \mathrm{x} 1 \mathrm{~m}$ excavation units (Figure 8). In all but one instance, excavation units were adjacent to at least one other unit and formed “excavation blocks”. Fourteen such excavation blocks, ranging in horizontal dimensions between $1 \mathrm{~m} \times 2 \mathrm{~m}(\mathrm{n}=4), 2 \mathrm{~m} \times 2 \mathrm{~m}(\mathrm{n}=8)$, and $3 \mathrm{~m} \times 3 \mathrm{~m}(\mathrm{n}=2)$, were excavated as 1 $\mathrm{m}$ x $1 \mathrm{~m}$ square units, generally in $5 \mathrm{~cm}$ levels, to a maximum depth of $120 \mathrm{~cm}$. One $1 \mathrm{~m}$ $\mathrm{x} 1 \mathrm{~m}$ excavation unit, isolated from other excavation units, was also excavated in $5 \mathrm{~cm}$ levels to a maximum depth of $120 \mathrm{~cm}$. All sediments, with the exception of those excavated from the plow zone and other mechanically-disturbed contexts, were sifted through hardware cloth.

Phase I deep testing was initiated in October 2002 and ran concurrently with Phase II site evaluation excavations until November 2002. Phase I deep testing consisted of the manual excavation of test units at three deep test sites, Deep Test 1, 2, and 3 (Figure 8). Deep Test 1 and 2 were located at sites of Phase II $2 \mathrm{~m} \times 2 \mathrm{~m}$ block excavations: Deep Test 1 was placed at the location of Block 5 (N425 E522) (Figure 9) and Deep Test 2 was placed at the location of Block 4 (N460 E500). Both Blocks 5 and 4 were excavated, in $5 \mathrm{~cm}$ levels, to approximately $120 \mathrm{~cm}$ depth prior to the establishment of Deep Test 1 and 2. A Kobelco ${ }^{\circledR}$ model SK210LC tracked excavator and Safety-Box ${ }^{\circledR}$ 


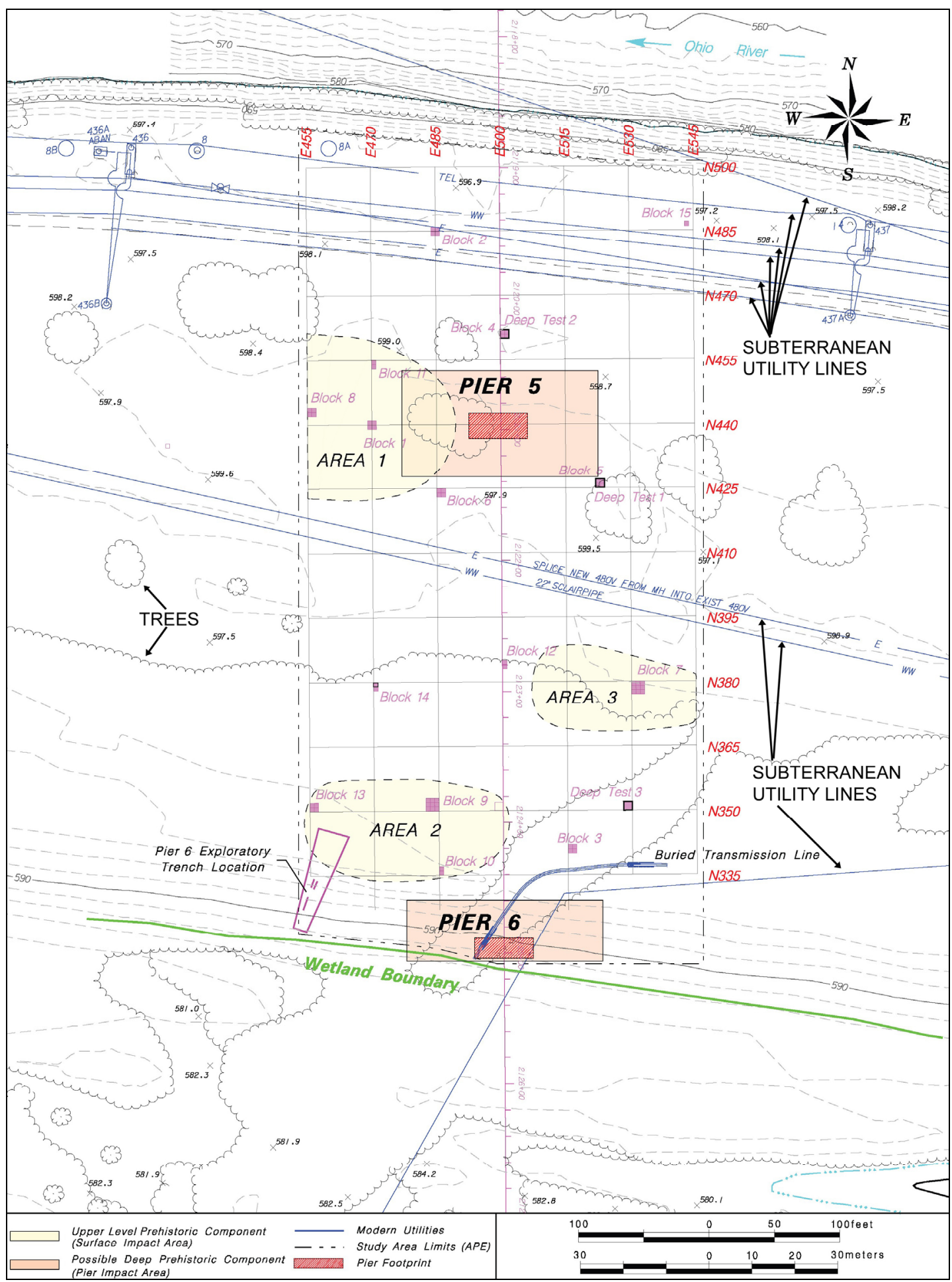

Figure 8: Map of the West Blennerhassett site showing the location of Phase II block excavations, Phase I deep tests, and Phase III excavations Area 1 and Pier 5. Also shown are the locations of proposed Phase III excavations at Area 2, Area 3, and Pier 6. Adapted from Robinson et al. (2008). 


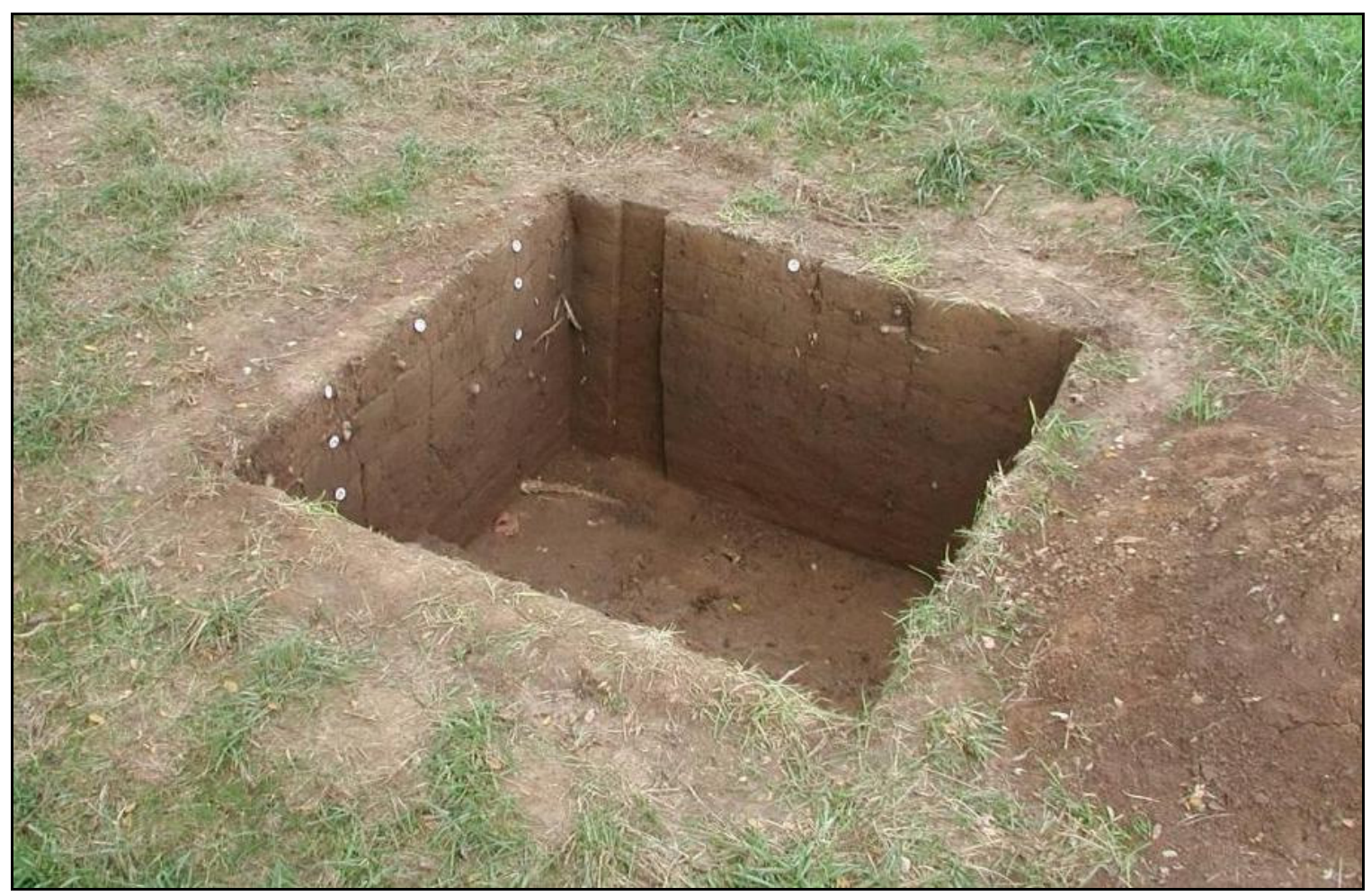

Figure 9: Southwest-facing view of Block 5, a Phase II $2 \mathrm{~m}$ x $2 \mathrm{~m}$ excavation at N425 E522, excavated to $\sim 120 \mathrm{~cm}$. Note Sediment Column 1 in the west wall of the block excavation. Photo was taken on 2 October 2002, immediately prior to the implementation of Deep Test 1. From Robinson et al. (2008).

trench boxes, measuring $10 \mathrm{ft}$ wide x $14 \mathrm{ft}$ long x $8 \mathrm{ft}$ high, were used in to facilitate manual excavations in Deep Tests 1 and 2 (Figures 10 and 11). Deep Tests 1 and 2 were excavated as $1 \mathrm{~m} \mathrm{x} 1 \mathrm{~m}$ units to depths of $\sim 4.8 \mathrm{~m}$ and $\sim 3.7 \mathrm{~m}$, respectively. Additional excavation units were excavated in Deep Test 1 upon the identification of intact early Holocene cultural strata between 2.97-3.60 m depth, and again between $\sim 4.20-4.60 \mathrm{~m}$ depth. Sediments in Deep Tests 1 and 2 were removed as $10 \mathrm{~cm}$ levels within natural strata and, with the exception of sediments retained for further laboratory analyses, were sifted through $0.64 \mathrm{~cm}$ (1/4 in) hardware cloth to facilitate artifact recovery. Deep Test 3, located at N350 E528, was established as a $1 \mathrm{~m}$ x $1 \mathrm{~m}$ excavation unit at a previously untested area of the site and was excavated in $5 \mathrm{~cm}$ levels to a depth of $120 \mathrm{~cm}$. All 
sediments excavated from Deep Test 3, except for laboratory analyses samples, were sifted through hardware cloth.

Phase III data recovery excavations were focused on the excavation of two partially overlapping excavation areas, Area 1 and Pier 5 (Figures 8 and 12). Both excavations were designed specifically to mitigate adverse impacts to cultural resources in the vicinity of the proposed bridge Pier 5. Excavation techniques for both Area 1 and Pier 5 included a combination of manual excavation of sample units, test units, and

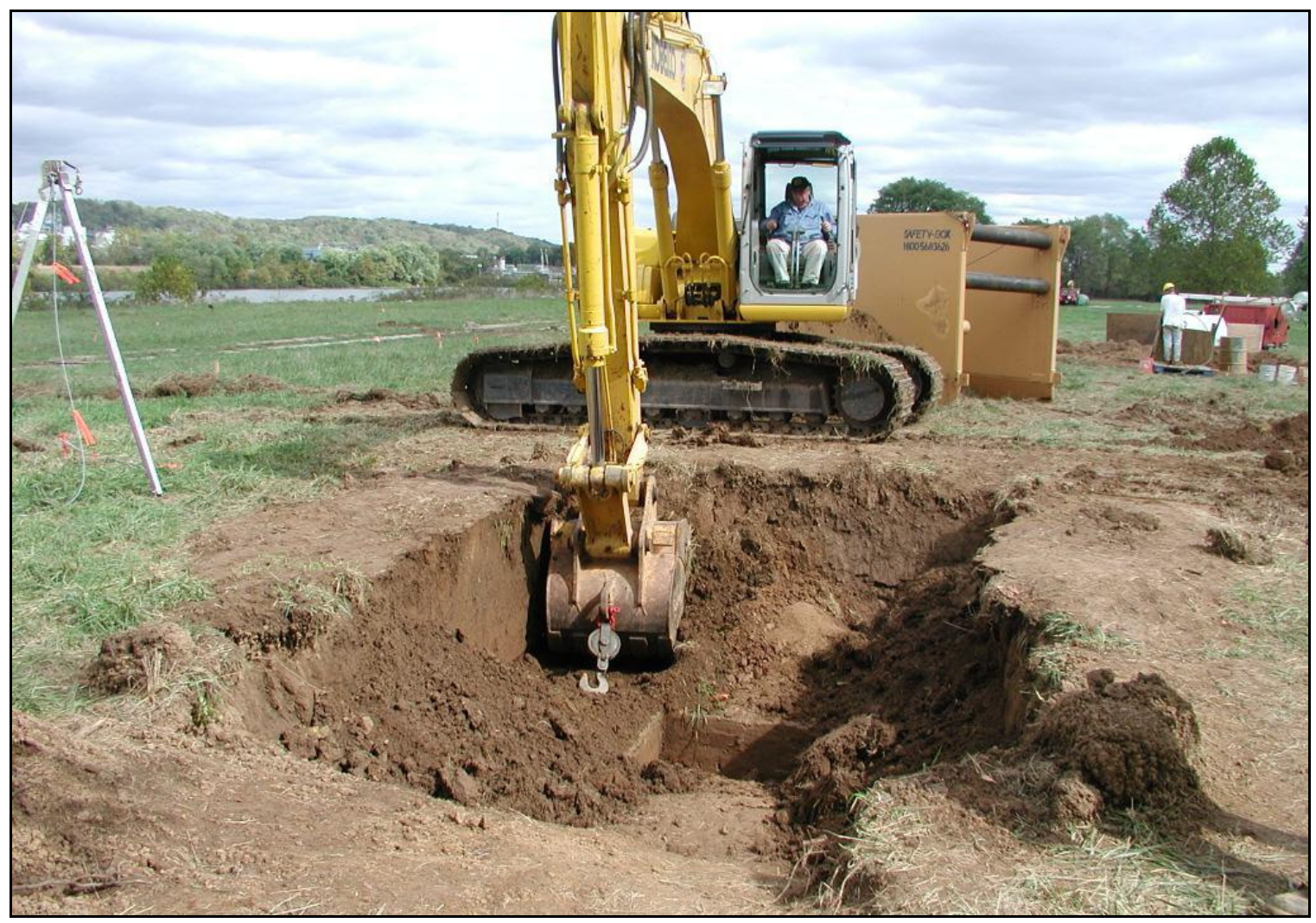

Figure 10: View of Deep Test 2 facing northeast on 5 October 2002. Note the $1 \mathrm{~m} \mathrm{x} 1 \mathrm{~m}$ test unit N460 E500 at the center of the trench, the trench box behind the tracked excavator, and the north channel of the Ohio River, flowing downstream to the left, in the left background of the photo. From Robinson et al. 2008. 


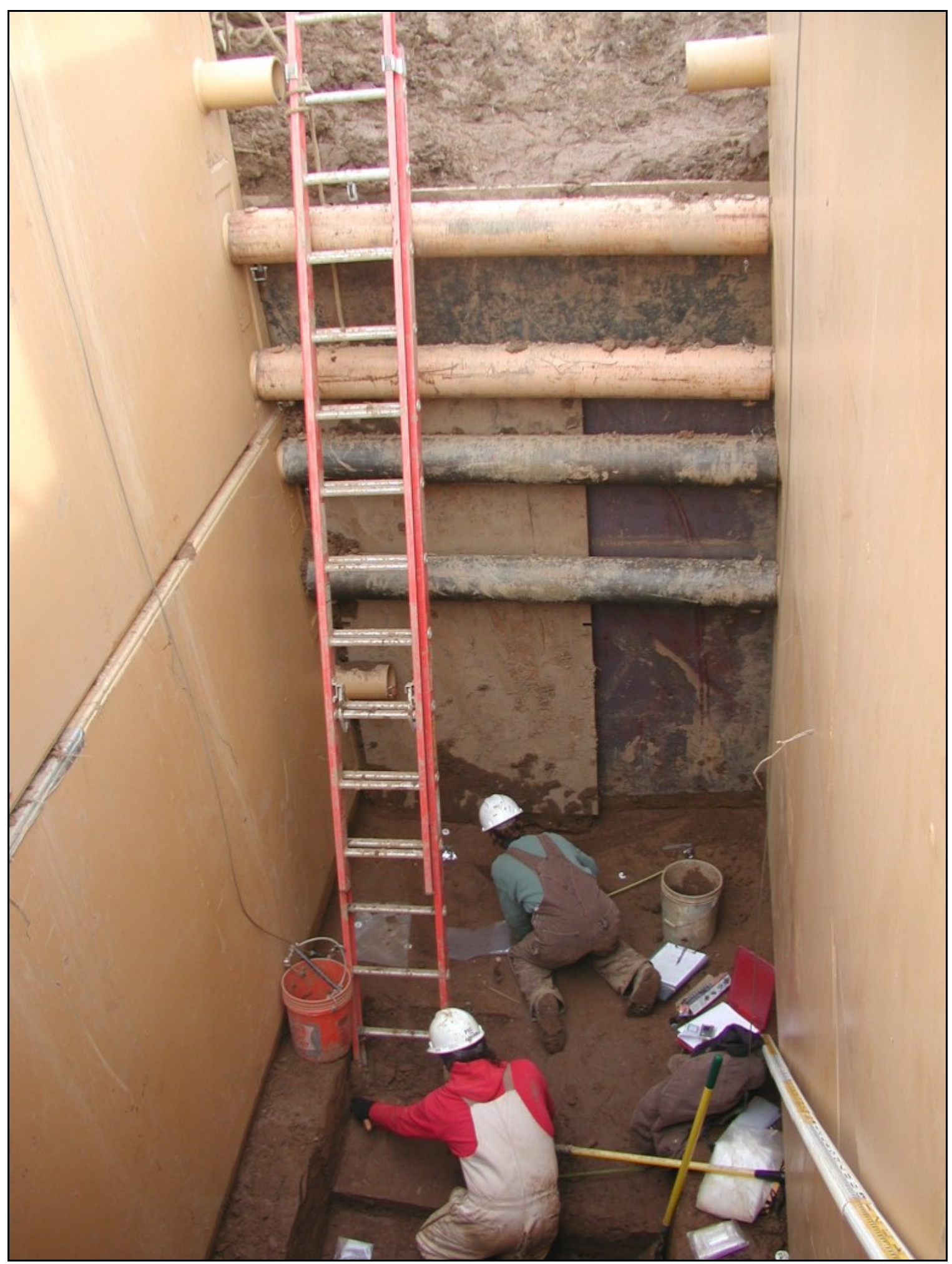

Figure 11: View of Deep Test 1, facing east-northeast, near the base of excavation on 18 November 2002. From Robinson et al. 2008. 


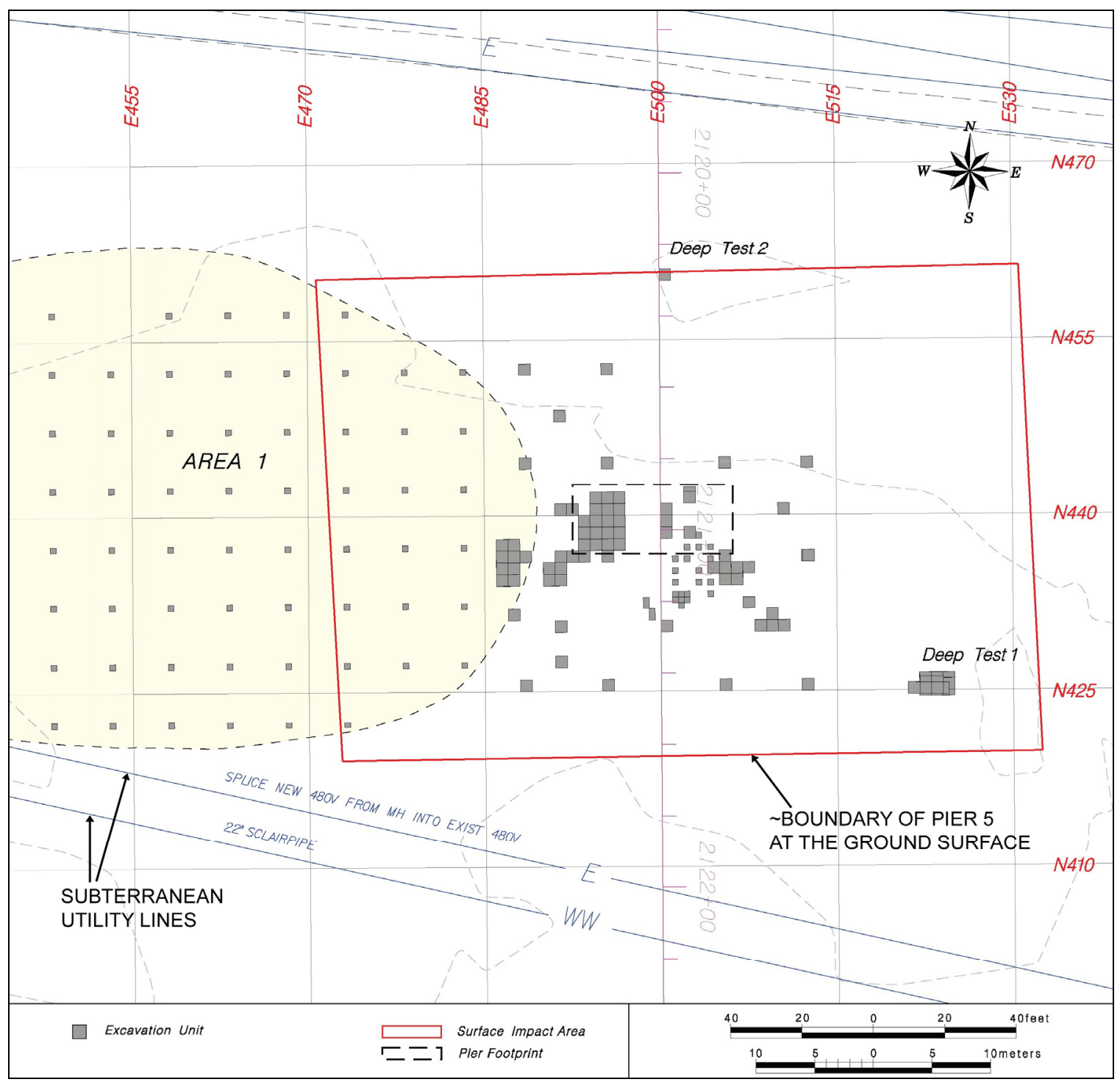

Figure 12: Map of the West Blennerhassett site showing the locations of manual excavation units in Deep Test 1, Deep Test 2, Area 1 and Pier 5. The Pier 5 excavation boundary is shown in red and is labeled as "surface impact area" in the legend. Adapted from Robinson et al. (2008).

cultural features and mechanical excavation of sediments using a John Deere ${ }^{\circledR}$ model 790 tracked excavator and a Gradall ${ }^{\circledR}$ model G-660 hydraulic excavator with a telescoping boom. All manually excavated sediments, except for laboratory analyses samples, were sifted through hardware cloth. Mechanical excavations were monitored by 
archaeological technicians who collected artifacts and documented archaeological deposits as they were encountered.

Area 1 was established between grid N422 and N458 and between grid E448 and E484 (Figures 8 and 12) and was excavated prior to excavation of Pier 5. Excavation of Area 1 began with the mechanical excavation of previously disturbed sediments from the plow zone (Ap horizon) down to the top of the underlying intact subsoil horizon. A total of $600.5 \mathrm{~m} \mathrm{x} 0.5 \mathrm{~m}$ sample units were then established at $5 \mathrm{~m}$ intervals along the site grid and were manually excavated in $5 \mathrm{~cm}$ levels, beginning at or near the top of the uppermost subsoil horizon and extending to various depths between 40 and $65 \mathrm{~cm}$. All sediments from these sample units were sifted through hardware cloth. The portion of Area 1 between grid N422 and N458 and between grid E467 and E484 was then mechanically excavated, generally in 5-10 cm increments, to a depth range of 70-105 cm below the ground surface (top of the Ap horizon).

The Pier 5 excavation was established between grid N419.2 and N460.8, and between grid E475.7 and E524.3. The western portion of Pier 5, between grid E475.7 and E484, overlapped with the eastern portion of Area 1; excavation of Area 1 preceded excavation of Pier 5 in this overlapping area. The north and south walls of the Pier 5 excavation were benched at an overall 1.5:1 ratio; horizontal benches approximately 180 cm wide were emplaced for every $120 \mathrm{~cm}$ of depth. The west and east ends of the excavation were ramped to provide access and egress for personnel and machinery.

Most sediment excavated from Pier 5 was removed using a Gradall to excavate in relatively thin, $\sim 5-10 \mathrm{~cm}$-thick, levels. The mechanical excavation strategy in the uppermost $\sim 200-250 \mathrm{~cm}$ of Pier 5 focused on opening horizontally broad portions of the 
excavation to similar elevations. As the excavation of Pier 5 proceeded below this depth, the mechanical excavation approach was modified to include the excavation of trenches, with relatively limited horizontal extent, within the floor of Pier 5 . The trenching strategy was adopted to facilitate investigation of deep sediments in a safe manner, as well as to facilitate manual excavation efforts in the deepest portions of Pier 5. For the most part, these trenches were temporary, they were eventually obliterated through mechanical excavation of the surrounding sediments, and are not identified as specific entities in latter sections of this thesis. However, two trenches excavated along a northsouth orientation in the central portion of Pier 5 and designated as the E500 Trench and E500 Trench Extension sampled some of the deepest and earliest archaeological and geological deposits at the site and are referred to by name throughout latter portions of this thesis. The E500 Trench and E500 Trench Extension were excavated during the final days of field work at the site and, unlike other trenches in Pier 5, the E500 Trench and E500 Trench Extension remained relatively intact until the termination of excavations at Pier 5. But, for most of the time that these trenches were exposed, the E500 Trench and E500 Trench Extension were filled with rain water from frequent showers. The E500 Trench Extension, in particular, was flooded immediately upon excavation and remained flooded throughout the remaining days of field work. As such, unsafe working conditions in the E500 Trench Extension precluded thorough documentation and sampling of respective deposits.

In addition to the Area 1 sample units that were excavated in the overlapping portion of Pier 5, a total of 95 manual excavation units, with horizontal dimensions ranging from $0.5 \mathrm{~m} \times 0.5 \mathrm{~m}$ to $1 \mathrm{~m} \times 1.2 \mathrm{~m}$, were excavated at various depths below 
179.69 m AMSL in Pier 5 (Figure 12). In most instances, sediments within these excavation units were excavated as arbitrary $5 \mathrm{~cm}$ levels within naturally defined geologic, pedologic, or anthropogenic strata. All sediments excavated from these units, except for laboratory analyses samples, were sifted through hardware cloth.

\section{Grid Elevation Conversions and Depth References}

As mentioned, all spatial data recorded during archaeological field work were referenced to the site grid. The Cartesian coordinate grid references (e.g. N500 E500) from the archaeological field work are maintained for this thesis, but grid elevation references have been converted to m AMSL and depth below ground surface references. Site grid elevations have been converted to m AMSL through correlation with the U.S. Route 50 project survey data. According to the U.S. Route 50 project mapping, the ground surface elevation at grid N500 E500 (station 2119+00) was 181.57 m AMSL. The archaeological grid elevation at N500 E500 was established as $100.00 \mathrm{~m}$. For the purpose of this thesis, all grid elevations were converted to m AMSL by adding $81.57 \mathrm{~m}$, the difference between the m AMSL and the arbitrary grid elevation at N500 E500.

Due to variation in excavation techniques between separate phases of archaeological investigation, it is difficult to determine depth below ground surface correlations with elevation references for many of the data. The original 2002 or 2003 elevations at the ground surface are known for some of the excavations discussed herein, particularly for Deep Tests 1 and 2. However, exact depth below ground surface correlations are impossible to determine for most of the spatial data because of limited mapping of the ground surface prior to excavation. Where the ground surface elevations are known, for example at Deep Tests 1 and 2, depth below ground surface references are 
stated without qualification. When referencing the elevations of data points from excavations where the ground surface elevations are not well-documented, depths are approximated with reference to the nearest known ground surface elevation and are qualified as approximate with the tilde $(\sim)$ symbol.

\section{Laboratory Methods}

Particle-size analysis was conducted on sediments from five vertically continuous sediment sample columns, Columns 1 through 5 ( at N425 E522, N460 E500, N440 E491, N440 E500, and N439 E496, respectively), at the Quaternary Geology Laboratory, Department of Geology and Geography, Morgantown, West Virginia. Particle-size analysis (granulometry) followed procedures outlined by Kite and Bell (1992) and Bell (1986). Dried sediment samples, ranging from 13 to $34 \mathrm{~g}$, were first wet sieved to separate the sample at the sand/silt break $(4 \mathrm{phi}=0.0625 \mathrm{~mm})$. The $<4$ phi $(>0.0625 \mathrm{~mm})$ fraction was dried again then separated into size classes at 1 phi intervals by passing the fraction through a stack of nested sieves. The $>4$ phi $(<0.0625 \mathrm{~mm})$ fraction was separated into size classes at 1 phi intervals by pipette analysis.

All weight measurements were recorded on lab worksheets then entered into a Microsoft Excel spreadsheet provided by Dr. J. Steven Kite (Appendix). This spreadsheet was used to calculate total weight per size class, percent of total sample weight for each size class, and conversion of USGS size classes at 1 phi intervals to approximated USDA sand, silt, and clay size classes.

Statistical parameters, including mean, sorting, skewness, and kurtosis, were calculated using Gradistat: A Grain Size Distribution and Statistics Package for the Analysis of Unconsolidated Sediments (Blott and Pye 2001). Gradistat calculates 
statistical parameters by the method of moments as well as by the Folk and Ward method.

The method of moments is a mathematical method, whereas the Folk and Ward method is a graphical method by which statistical parameters are approximated "by plotting frequency data as a cumulative frequency curve, extracting prescribed values from the curve and entering these into established formulae” (Blott and Pye 2001:1240). Blott and Pye (2001) suggest that the method of moments is the more accurate of the two methods because it makes use of the entire sample population. However, Blott and Pye (2001) also note that statistics calculated by the method of moments are more affected by outliers in the tails of the distribution. In contrast, statistical parameters calculated by the Folk and Ward method are less sensitive to outliers in the tails of the distribution (Blott and Pye 2001). Statistical parameters by the method of moments are cited within the body of this thesis; both the method of moments and the Folk and Ward statistics are presented in the Appendix.

\section{Results}

Interpreting the landform evolution and natural site formation processes at West Blennerhassett necessitates the identification, analyses, and characterization of individual sedimentary, pedologic, and archaeological stratigraphic units. The establishment of a temporal framework is essential for ordering the sedimentary and archaeological stratigraphies along a common scale. Observations made during archaeological excavations and results of subsequent laboratory analyses are presented in four sections: Radiocarbon Chronology, Sedimentology, Pedology, and Cultural Stratigraphy. Results presented in each of the respective sections are primarily derived from observations and data collected during the concurrent Phase I deep testing and Phase II site evaluation excavations in 2002 and from the Phase III data recovery excavations in 2003. 
Accordingly, the excavations described as Deep Test 1, Deep Test 2, Area 1, and Pier 5 serve as focal points in the following presentation of results.

An overview of the assemblage of ${ }^{14} \mathrm{C}$ ages from West Blennerhassett is presented in the radiocarbon chronology section. Individual ${ }^{14} \mathrm{C}$ ages and generalized age ranges are discussed in the sedimentology and cultural stratigraphy as they pertain to each of the respective sections. The sedimentology section is based largely on results from particlesize analysis conducted in a laboratory setting and is supplemented by observations made during excavations. The pedology section is based primarily on observations of soil morphological characteristics that are supported by relevant particle-size analysis data and correlation with theoretical models of alluvial soil formation. Results presented in the cultural stratigraphy section are derived from a combination of field observations, laboratory analysis, and correlation with well-established regional cultural chronologies.

Each of the sedimentology and cultural stratigraphy has their own stratigraphies; sedimentary units are the principal stratigraphic units associated with the sedimentology and cultural strata are the principal stratigraphic units associated with the cultural stratigraphy. The respective stratigraphies are described and correlated with relevant ${ }^{14} \mathrm{C}$ age determinations in each of the Sedimentology and Cultural Stratigraphy sections. Convention pedological nomenclature is used to describe soil horizons in the Pedology section.

\section{Radiocarbon Chronology}

The West Blennerhassett radiocarbon chronology is derived from $35{ }^{14} \mathrm{C}$ age determinations made on carbonized floral samples, carbonized nutshell, wood charcoal, and, in one instance, a single carbonized seed, that were recovered from sound 
archaeological context. Thirty-four of the carbonized floral samples were recovered from cultural features; one sample was recovered from archaeological context in an arbitrary 5 cm excavation level in test unit N434 E456. The assemblage of radiocarbon samples was selected from various vertical proveniences and stratigraphic contexts in order to address a combination of anthropologically oriented problems and geoarchaeological concerns. Samples were submitted to Illinois State Geological Survey (ISGS) for radiocarbon dating by the accelerator mass spectrometer (AMS) method. Two samples, ISGS-A0891 and ISGS-A0901, returned assays that are not concordant with the general trends; the results of these two samples are largely omitted from further discussion. The remaining 33 age determinations span much of the Holocene and are discussed herein with reference to their uncalibrated radiocarbon years before present (B.P.) ages. All 35 radiocarbon dates are listed in Table 2, along with 1-sigma counting errors, ISGS laboratory identification numbers, provenience information, material analyzed, and isotopic fractionation $\left(\delta^{13} \mathrm{C}\right)$ values. Thirty four of the 35 radiocarbon dates are plotted, with 2-sigma error bars, by depth in Figure 13; ISGS-A0891 (>46,300 B.P.) is interpreted to be reworked from a much older deposit and is not shown in Figure 13.

The chronology established from ${ }^{14} \mathrm{C}$ age determinations from West Blennerhassett proper is supplemented by two radiocarbon ages reported by Simard (1989) from nearby provenience. In a study of the lower terraces and floodplains of the upper Ohio River Valley, Simard (1989:71) reported radiocarbon dates of $5000 \pm 70$ B.P. (Beta-18553) and $5120 \pm 300$ yr. B.P. (W-5884) for two specimens of elm (genus Ulmus) logs from Blennerhassett Island. The elm logs were recovered during the excavation of E. I. DuPont De Nemours and Company (DuPont) water well \#436 (Figure 7), from 
Table 2: West Blennerhassett Radiocarbon Dates.

\begin{tabular}{|c|c|c|c|c|c|c|c|c|}
\hline $\begin{array}{l}\text { ISGS } \\
\text { Lab } \\
\text { No. }\end{array}$ & $\begin{array}{c}\text { Feat } \\
\text { No. or Test } \\
\text { Unit } \\
\text { Coordinates }\end{array}$ & $\begin{array}{c}\text { Feature } \\
\text { Center } \\
\text { Point or } \\
\text { Test } \\
\text { Unit }^{\mathrm{a}}\end{array}$ & $\begin{array}{l}\text { Elevation } \\
\text { or } \\
\text { Elevation } \\
\text { Range (m } \\
\text { AMSL }^{\text {b }}\end{array}$ & $\begin{array}{c}\text { Grid } \\
\text { Elevation } \\
\text { or } \\
\text { Elevation } \\
\text { Range } \\
\text { (m) }\end{array}$ & $\begin{array}{c}\text { Uncalib. } \\
\text { age } \\
\text { (radio- } \\
\text { carbon } \\
\text { yr B.P.) }\end{array}$ & $\begin{array}{l}\text { Counting } \\
\text { Error } \\
\text { (radio- } \\
\text { carbon } \\
\text { yr) }\end{array}$ & $\begin{array}{l}\text { Carbonized } \\
\text { Material } \\
\text { Analyzed }\end{array}$ & $\delta^{13} \mathrm{C}$ \\
\hline A0903 & N443 E456 & $\begin{array}{l}\mathrm{N} 443 \\
\mathrm{E} 456\end{array}$ & $\begin{array}{l}181.71- \\
181.66\end{array}$ & $\begin{array}{c}100.14- \\
100.09 \\
\end{array}$ & 2225 & \pm 30 & $\begin{array}{c}1 \mathrm{pc} . / 0.020 \mathrm{~g} \\
\text { walnut (Juglans } \\
\text { sp.) nutshell }\end{array}$ & -28.1 \\
\hline A0884 & 17 & $\begin{array}{l}\text { N440.14 } \\
\text { E470.06 }\end{array}$ & 181.66 & 100.09 & 2885 & \pm 30 & $\begin{array}{c}1 \mathrm{pc} . / 0.025 \mathrm{~g} \\
\text { butternut (Juglans } \\
\text { cinerea) nutshell }\end{array}$ & -28.4 \\
\hline A0893 & 117 & $\begin{array}{l}\text { N424.82 } \\
\text { E476.53 }\end{array}$ & 181.66 & 100.09 & 1960 & \pm 30 & $\begin{array}{c}1 \mathrm{pc} . / 0.030 \mathrm{~g} \\
\text { walnut (Juglans } \\
\text { sp.) nutshell }\end{array}$ & -25.6 \\
\hline A0887 & 64 & $\begin{array}{l}\mathrm{N} 459.16 \\
\mathrm{E} 461.86\end{array}$ & 181.54 & 99.97 & 1375 & \pm 30 & $\begin{array}{c}1 \mathrm{pc} . / 0.015 \mathrm{~g} \\
\text { walnut (Juglans } \\
\text { sp.) nutshell }\end{array}$ & -24.6 \\
\hline A0863 & 52 & $\begin{array}{l}\text { N420.60 } \\
\text { E478.10 }\end{array}$ & 181.43 & 99.86 & 2595 & \pm 30 & $\begin{array}{c}1 \mathrm{pc} . / 0.015 \mathrm{~g} \\
\text { hickory (Carya sp.) } \\
\text { nutshell }\end{array}$ & -26 \\
\hline A0892 & 134 & $\begin{array}{l}\text { N435.09 } \\
\text { E468.60 }\end{array}$ & 181.36 & 99.79 & 3120 & \pm 30 & $\begin{array}{c}1 \mathrm{pc} . / 0.025 \mathrm{~g} \\
\text { butternut (Juglans } \\
\text { cinerea) nutshell }\end{array}$ & -26.4 \\
\hline A0861 & 129 & $\begin{array}{l}\text { N439.83 } \\
\text { E469.47 }\end{array}$ & 181.34 & 99.77 & 3000 & \pm 30 & $\begin{array}{c}1 \mathrm{pc} . / 0.035 \mathrm{~g} \text { black } \\
\text { walnut (Juglans } \\
\text { nigra) nutshell }\end{array}$ & -27.1 \\
\hline A0864 & 174 & $\begin{array}{l}\text { N422.52 } \\
\text { E476.97 }\end{array}$ & 181.28 & 99.71 & 3105 & \pm 30 & $\begin{array}{c}1 \mathrm{pc} . / 0.055 \mathrm{~g} \\
\text { hickory (Carya sp.) } \\
\text { nutshell }\end{array}$ & -25.3 \\
\hline A0862 & 163 & $\begin{array}{l}\mathrm{N} 425.33 \\
\mathrm{E} 477.69\end{array}$ & 181.14 & 99.57 & 3055 & \pm 35 & $\begin{array}{c}1 \mathrm{pc} . / 0.070 \mathrm{~g} \text { black } \\
\text { walnut (Juglans } \\
\text { nigra) nutshell }\end{array}$ & -27 \\
\hline A0888 & 70 & $\begin{array}{l}\text { N433.82 } \\
\text { E516.55 }\end{array}$ & 180.87 & 99.30 & 2855 & \pm 30 & $\begin{array}{c}1 \mathrm{pc} . / 0.020 \mathrm{~g} \\
\text { walnut (Juglans } \\
\text { sp.) nutshell }\end{array}$ & -26.9 \\
\hline A0894 & 101 & $\begin{array}{l}\text { N442.76 } \\
\text { E503.83 }\end{array}$ & 180.86 & 99.29 & 4315 & \pm 30 & $\begin{array}{c}1 \mathrm{pc} . / 0.035 \mathrm{~g} \\
\text { hickory (Carya sp.) } \\
\text { nutshell }\end{array}$ & -23.7 \\
\hline A0891 & 155 & $\begin{array}{l}\mathrm{N} 442.51 \\
\mathrm{E} 487.23 \\
\end{array}$ & 179.68 & 98.11 & $>46,300$ & N/A & $\begin{array}{c}1 \mathrm{pc} . / 0.010 \mathrm{~g} \\
\text { hickory (Carya sp.) } \\
\text { nutshell }\end{array}$ & -23.1 \\
\hline A0860 & 160 & $\begin{array}{l}\mathrm{N} 431.45 \\
\mathrm{E} 502.24\end{array}$ & 179.57 & 98.00 & 7010 & \pm 40 & $\begin{array}{c}24 \text { pcs. } / 0.015 \mathrm{~g} \\
\text { unidentified wood } \\
\text { charcoal }\end{array}$ & -25.4 \\
\hline A0881 & 36 & $\begin{array}{l}\text { N425.02 } \\
\text { E522.65 }\end{array}$ & 178.86 & 97.29 & 7825 & \pm 40 & $\begin{array}{c}1 \mathrm{pc} . / 0.010 \mathrm{~g} \\
\text { walnut (Juglans } \\
\text { sp.) nutshell } \\
\end{array}$ & -27.9 \\
\hline A0882 & 41 & $\begin{array}{l}\text { N426.27 } \\
\text { E524.44 }\end{array}$ & 178.75 & 97.18 & 7965 & \pm 35 & $\begin{array}{c}1 \mathrm{pc} . / 0.020 \mathrm{~g} \\
\text { hickory (Carya sp.) } \\
\text { nutshell }\end{array}$ & -27.2 \\
\hline A0901 & 215 & $\begin{array}{l}\text { N429.63 } \\
\text { E510.29 }\end{array}$ & 178.73 & 97.16 & 3070 & \pm 35 & $\begin{array}{c}1 \mathrm{pc} . / 0.020 \mathrm{~g} \\
\text { hickory (Carya sp.) } \\
\text { nutshell }\end{array}$ & -24.6 \\
\hline A0872 & 209 & $\begin{array}{l}\text { N439.62 } \\
\text { E487.81 }\end{array}$ & 178.72 & 97.15 & 7985 & \pm 35 & $\begin{array}{c}1 \mathrm{pc} . / 0.020 \mathrm{~g} \\
\text { butternut (Juglans } \\
\text { cinerea) nutshell }\end{array}$ & -26.3 \\
\hline A0873 & 243 & $\begin{array}{l}\text { N434.26 } \\
\text { E502.13 }\end{array}$ & 178.70 & 97.13 & 8020 & \pm 35 & $\begin{array}{c}3 \text { pcs. } / 0.015 \mathrm{~g} \\
\text { unidentified wood } \\
\text { charcoal }\end{array}$ & -25.2 \\
\hline A0868 & 235 & $\begin{array}{l}\text { N432.28 } \\
\text { E507.47 }\end{array}$ & 178.69 & 97.12 & 7845 & \pm 25 & $\begin{array}{c}1 \mathrm{pc} . / 0.030 \mathrm{~g} \text { white } \\
\text { oak group (Quercus } \\
\text { subg. Quercus) } \\
\text { wood charcoal }\end{array}$ & -26 \\
\hline A0889 & 227 & $\begin{array}{l}\text { N434.67 } \\
\text { E500.58 }\end{array}$ & 178.69 & 97.12 & 7910 & \pm 35 & $\begin{array}{c}1 \mathrm{pc} . / 0.015 \mathrm{~g} \\
\text { hickory (Carya sp.) } \\
\text { nutshell }\end{array}$ & -26 \\
\hline
\end{tabular}


Table 2 (continued)

\begin{tabular}{|c|c|c|c|c|c|c|c|c|}
\hline $\begin{array}{l}\text { ISGS } \\
\text { Lab } \\
\text { No. }\end{array}$ & $\begin{array}{c}\text { Feat } \\
\text { No. or Test } \\
\text { Unit } \\
\text { Coordinates }\end{array}$ & $\begin{array}{c}\text { Feature } \\
\text { Center } \\
\text { Point or } \\
\text { Test } \\
\text { Unit }^{\mathrm{a}}\end{array}$ & $\begin{array}{l}\text { Elevation } \\
\text { or } \\
\text { Elevation } \\
\text { Range (m } \\
\text { AMSL) }\end{array}$ & $\begin{array}{c}\text { Grid } \\
\text { Elevation } \\
\text { or } \\
\text { Elevation } \\
\text { Range } \\
\text { (m) } \\
\end{array}$ & $\begin{array}{l}\text { Uncalib. } \\
\text { (radio- } \\
\text { carbon } \\
\text { yr B.P.) }\end{array}$ & $\begin{array}{l}\text { Counting } \\
\text { Error } \\
\text { (radio- } \\
\text { carbon } \\
\text { yr) }\end{array}$ & $\begin{array}{l}\text { Carbonized } \\
\text { Material } \\
\text { Analyzed }\end{array}$ & $\delta^{13} \mathrm{C}$ \\
\hline A0899 & 231 & $\begin{array}{l}\mathrm{N} 432.35 \\
\mathrm{E} 501.52\end{array}$ & 178.69 & 97.12 & 7760 & \pm 35 & $\begin{array}{c}1 \mathrm{pc} . / 0.010 \mathrm{~g} \\
\text { walnut family } \\
\text { (Juglandaceae) } \\
\text { nutshell }\end{array}$ & -24.3 \\
\hline A0869 & 183 & $\begin{array}{l}N 438.00 \\
E 500.00\end{array}$ & 178.68 & 97.11 & 7940 & \pm 30 & $\begin{array}{c}3 \mathrm{pcs} . / 0.015 \mathrm{~g} \\
\text { unidentified wood } \\
\text { charcoal }\end{array}$ & -24.3 \\
\hline A0902 & 230 & $\begin{array}{l}\mathrm{N} 431.97 \\
\mathrm{E} 501.17\end{array}$ & 178.68 & 97.11 & 8075 & \pm 35 & $\begin{array}{c}\text { Many very small } \\
\text { pieces } / 0.010 \mathrm{~g} \\
\text { unidentified wood } \\
\text { charcoal } \\
\end{array}$ & -27 \\
\hline A0900 & 239 & $\begin{array}{l}\text { N436.00 } \\
\text { E508.22 }\end{array}$ & 178.60 & 97.03 & 8005 & \pm 35 & $\begin{array}{c}1 \mathrm{pc} . / 0.030 \mathrm{~g} \\
\text { walnut (Juglans } \\
\text { sp.) nutshell }\end{array}$ & -23.2 \\
\hline A0904 & 250 & $\begin{array}{l}\mathrm{N} 445.95 \\
\mathrm{E} 494.86 \\
\end{array}$ & 178.35 & 96.78 & 7850 & \pm 35 & $\begin{array}{c}2 \mathrm{pc} . / 0.010 \mathrm{~g} \\
\text { unidentified nutshell }\end{array}$ & -27.3 \\
\hline A0880 & 262 & $\begin{array}{l}\text { N432.97 } \\
\text { E504.91 }\end{array}$ & 178.20 & 96.63 & 8165 & \pm 35 & $\begin{array}{c}1 \text { pc./0.025 g } \\
\text { hickory (Carya sp.) } \\
\text { nutshell } \\
\end{array}$ & -26 \\
\hline A0879 & 263 & $\begin{array}{l}N 432.38 \\
E 505.79\end{array}$ & 178.19 & 96.62 & 8025 & \pm 35 & $\begin{array}{c}1 \text { pc./0.020 g } \\
\text { hickory (Carya sp.) } \\
\text { nutshell } \\
\end{array}$ & -25.5 \\
\hline A0870 & 50 & $\begin{array}{l}\text { N425 } \\
\text { E525 }\end{array}$ & 177.67 & 96.10 & 8235 & \pm 40 & $\begin{array}{c}5 \text { pcs. } / 0.015 \mathrm{~g} \\
\text { unidentified } \\
\text { hardwood wood } \\
\text { charcoal }\end{array}$ & -26.7 \\
\hline A0885 & 48 & $\begin{array}{l}\text { N426.02 } \\
\text { E524.98 }\end{array}$ & 177.66 & 96.09 & 8245 & \pm 35 & $\begin{array}{c}1 \mathrm{pc} . / 0.015 \mathrm{~g} \\
\text { walnut family } \\
\text { (Juglandaceae) } \\
\text { nutshell }\end{array}$ & -24.7 \\
\hline A0906 & 272 & $\begin{array}{l}N 438.30 \\
E 493.30\end{array}$ & 177.55 & 95.98 & 8340 & \pm 40 & $\begin{array}{c}9 \mathrm{pcs} . / 0.100 \mathrm{~g} \\
\text { unidentified wood } \\
\text { charcoal }\end{array}$ & -25.1 \\
\hline A0886 & 273 & $\begin{array}{l}\text { N438.43 } \\
\text { E495.64 }\end{array}$ & 177.24 & 95.67 & 8215 & \pm 35 & $\begin{array}{c}3 \text { pcs. } / 0.020 \mathrm{~g} \\
\text { maple (Acer sp.) } \\
\text { wood charcoal }\end{array}$ & -24.6 \\
\hline A0871 & 276 & $\begin{array}{l}N 438.11 \\
E 496.47\end{array}$ & 177.24 & 95.67 & 8355 & \pm 30 & $\begin{array}{c}1 \text { pc. } / 0.025 \mathrm{~g} \text { black } \\
\text { walnut (Juglans } \\
\text { nigra) nutshell }\end{array}$ & -24.7 \\
\hline A0905 & 282 & $\begin{array}{l}\mathrm{N} 430.35 \\
\mathrm{E} 496.44 \\
\end{array}$ & 177.23 & 95.66 & 8265 & \pm 35 & $\begin{array}{c}1 \mathrm{pc} . / 0.005 \mathrm{~g} \\
\text { unidentified nutshell }\end{array}$ & -23.5 \\
\hline A0883 & 288 & $\begin{array}{c}\text { N438- } \\
\text { N440.50 } \\
\text { E494- } \\
\text { E497 } \\
\end{array}$ & $\begin{array}{l}177.23- \\
177.05\end{array}$ & $\begin{array}{l}95.66- \\
95.48\end{array}$ & 8660 & \pm 40 & $\begin{array}{c}1 \text { pc./0.025 g red } \\
\text { oak (Quercus subg. } \\
\text { Lobatae) wood } \\
\text { charcoal }\end{array}$ & -25 \\
\hline A0890 & 268 & $\begin{array}{l}\mathrm{N} 447.94 \\
\mathrm{E} 495.05 \\
\end{array}$ & 176.56 & 94.99 & 8360 & \pm 50 & $\begin{array}{c}1 \mathrm{pc} / 0.015 \mathrm{~g} \text { grape } \\
\text { (Vitus sp.) seed }\end{array}$ & -25 \\
\hline
\end{tabular}

${ }^{\mathrm{a}}$ Coordinate at the south west corner of $1 \mathrm{~m} \times 1 \mathrm{~m}$ test unit.

${ }^{\mathrm{b}}$ Feature elevation measured from the center point at top of feature, test unit elevation range measured at the center of test unit. 


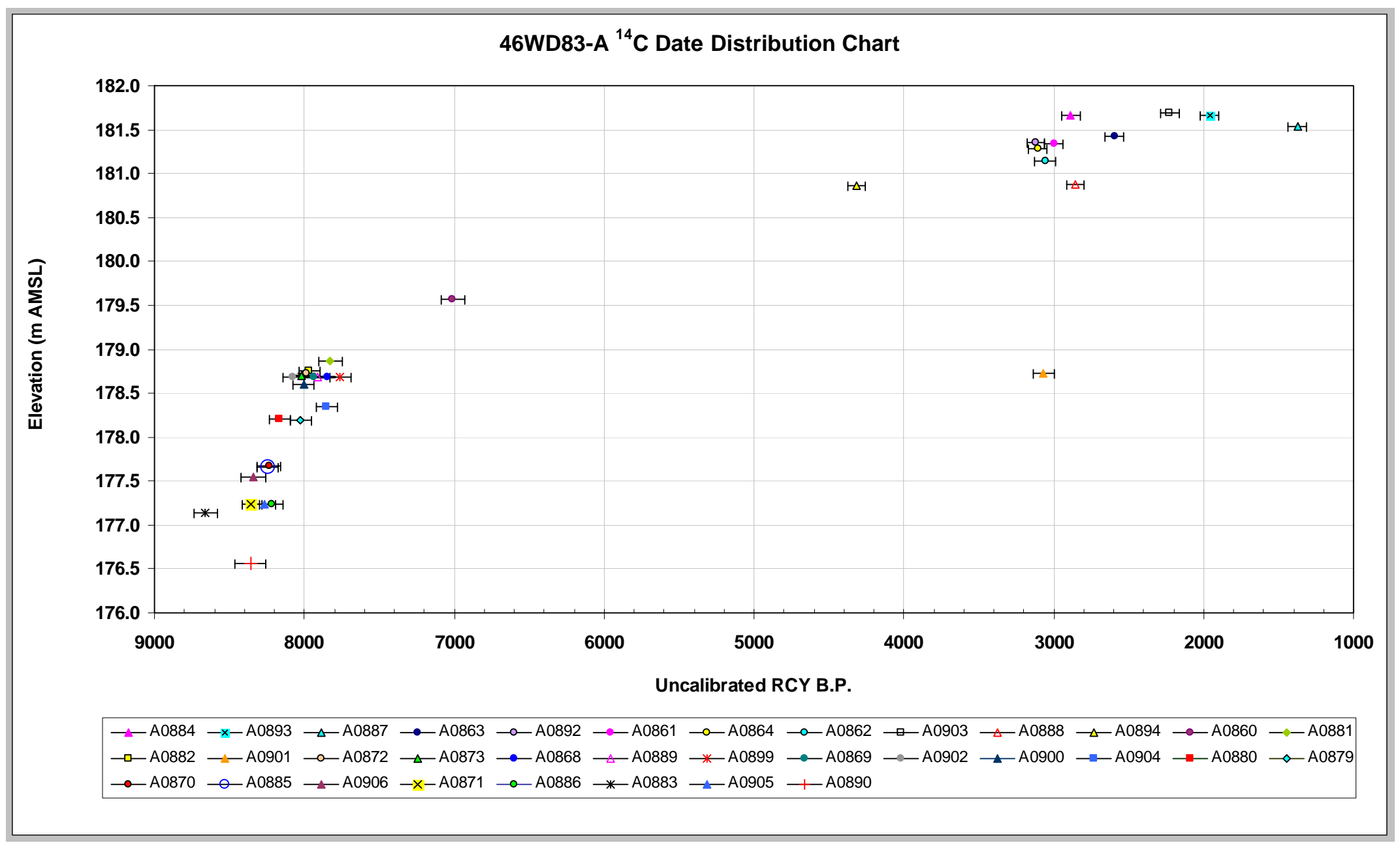

Figure 13: West Blennerhassett radiocarbon date distribution chart. Error bars are shown at two counting errors. ISGS-A0891 (>46,300 B.P.) is not shown. Elevation $181.57 \mathrm{~m}$ AMSL is equal to grid elevation $100.00 \mathrm{~m}$. 
below $9 \mathrm{~m}$ (30 ft) of silty clay and $4 \mathrm{~m}$ (13 ft) of sand and gravel in an alluvial deposit that was reported to total $17.5 \mathrm{~m}$ (57.3 ft) thick (Simard 1989:71). Well \#436 is located at approximately grid N505 E415, within approximately $110 \mathrm{~m}$ (361 ft) northwest of the center of Pier 5 (N440 E500) (Figure 7). Though well \#436 and the associated ${ }^{14} \mathrm{C}$ ages are not from within the site boundaries per se, the close proximity of the samples to the site proper warrants their consideration along with the dates obtained in this study.

\section{Sedimentology}

The West Blennerhassett sedimentology is based primarily on results from particle-size analysis of sediments recovered from vertically continuous sediment sample columns at five locations across the site. Three sedimentary units are defined by trends in particle-size distribution as identified through particle size analysis; a fourth sedimentary unit is defined based on well-preserved depositional attributes observed near the bottom of the excavation during field investigations.

Sediment samples for particle-size analysis were collected from continuous sample columns in units N425 E522 (Block 5/Deep Test 1) and N460 E500 (Block 4/Deep Test 2) during the Phase II site evaluation and Phase I deep testing in 2002, and from units N440 E491, N440 E500, and N439 E496 in Pier 5 during the 2003 Phase III data recovery excavations. These sediment sample columns are designated Columns 1 through 5 for N425 E522, N460 E500, N440 E491, N440 E500, and N439 E496, respectively (Figure 14).

Column 1 and Column 2 are the most vertically extensive and are deemed to be generally representative of sediments in the upper 3 to $4 \mathrm{~m}$ of the area under consideration. Both columns began at the ground surface and extended to the base of 


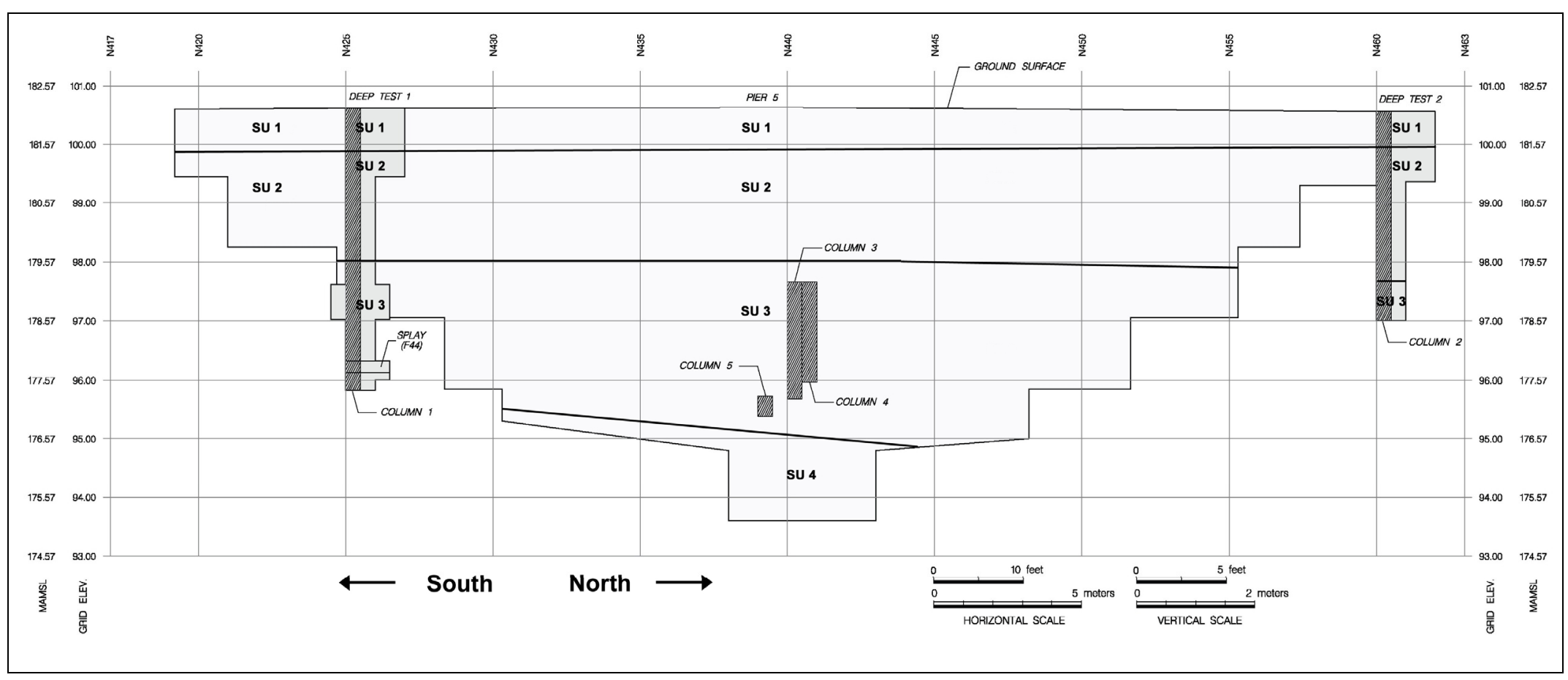

Figure 14: Generalized profile of Deep Test 1, Deep Test 2, and Pier 5 facing downriver (west) and showing Sedimentary Units 1 through 4, Sediment Sample Columns 1 through 5, and the F44 splay with vertical exaggeration of 2. 
excavation in Deep Test 1 and Deep Test 2, 480 and 368 cm depth (177.39 and $178.45 \mathrm{~m}$ AMSL), respectively. The top $120 \mathrm{~cm}$ of sediment in each of these two columns was sampled in $5 \mathrm{~cm}$ increments within field designated F\# strata during Phase II block excavations. The remaining portion of each profile, below $120 \mathrm{~cm}$ depth, was sampled in $10 \mathrm{~cm}$ increments within field designated F\# strata as part of the Phase I deep testing efforts.

Both Column 3 and Column 4 began at 296 cm depth (179.24 m AMSL) and were recovered in $5 \mathrm{~cm}$ increments within field designated F\# strata. Column 3 extended to $496 \mathrm{~cm}$ depth (177.24 m AMSL); Column 4 extended to $466 \mathrm{~cm}$ depth $(177.54 \mathrm{~m}$ AMSL). Column 5 extended only $34 \mathrm{~cm}$ from $\sim 491$ to $~ 525 \mathrm{~cm}$ depth (177.29 to 176.95 m AMSL), but contained the deepest sampled sediments from the site. Furthermore, Column 5 extended from immediately above, through, and to the levels immediately below one of the earliest, discrete cultural components at the site, OC 4 (see Cultural Stratigraphy). Samples from Column 5 were collected in $5 \mathrm{~cm}$ increments within field designated F\# strata.

Results of particle-size analysis of sediments from Column 1 and Column 2 indicate three distinct sedimentary units (SU): SU 1 is a unit of relatively coarse-textured sediments from $\sim 62$ and $75 \mathrm{~cm}$ depth to the ground surface, SU 2 is an $200 \mathrm{~cm}$-thick unit of fine-textured sediments, and SU 3 is a unit of coarse-textured sediments that generally fines upward and is characterized by relatively variable particle-size distribution. SU 1 and SU 2 could not be sampled in Columns 3, 4, and 5; these columns appear to represent samples of the SU 3 sediments exclusively. The existence of SU 1 and SU 2 in the Area 1 and Pier 5 excavations is inferred from observed similarities and 
continuities between the soils and sediments in these excavation areas and Deep Test 1 and Deep Test 2.

Sedimentary Unit 4 was identified only in the deepest portion of the Pier 5 excavation in the final days of field work. SU 4 is identified primarily by the presence of relatively well-preserved depositional strata as observed during excavation: alternating beds of loam and clay loam textured sediments dipping northward at $\sim$ five percent. Time constraints and ponding due to heavy rainfall at the end of the excavation season precluded thorough documentation and sampling of SU 4.

Sedimentary Units 1 through 4 are described in detail below. The sedimentary units and sediment sample columns are shown in a generalized profile in Figure 14 and are listed with their respective vertical distributions as well as corresponding field designations, soil horizons, and radiocarbon ages in Table 3. Representative sedimentation rate ranges, measured for each of the sedimentary units, are provided at the end of this section.

\section{Sedimentary Unit 1 (SU 1)}

SU 1 is characterized by relatively coarse-textured sediments and slow sedimentation rates. SU 1 began at the ground surface in samples from Columns 1 and 2 (182.19 and 182.13 m AMSL, respectively) and extended to $75 \mathrm{~cm}$ depth (181.44 m AMSL) in Column 1 and $60 \mathrm{~cm}$ depth (181.53 m AMSL) in Column 2 (Figures 15 and 16). SU 1 sediments in the Area 1 and Pier 5 excavations were not sampled for particlesize analysis. However, based on correlation with Columns 1 and 2, SU 1 presumably existed at similar depths in these areas. 
Table 3: West Blennerhassett sedimentary unit correlation table.

\begin{tabular}{|c|c|c|c|c|c|c|c|}
\hline $\begin{array}{l}\text { Sedimentary } \\
\text { Unit }\end{array}$ & $\begin{array}{c}\text { Elevation } \\
\text { Range (m } \\
\text { AMSL) } \\
\text { Deep Test } 1\end{array}$ & $\begin{array}{l}\text { Elevation } \\
\text { Range (m } \\
\text { AMSL) } \\
\text { Deep Test } 2\end{array}$ & $\begin{array}{l}\text { Elevation } \\
\text { Range (m } \\
\text { AMSL) } \\
\text { Pier } 5 \\
\text { South } \\
\end{array}$ & $\begin{array}{l}\text { Elevation } \\
\text { Range (m } \\
\text { AMSL) } \\
\text { Pier } 5 \\
\text { North } \\
\end{array}$ & $\begin{array}{c}\text { Field } \\
\text { Designations } \\
(\mathrm{F \# )}\end{array}$ & $\begin{array}{c}\text { Soil } \\
\text { Horizons }\end{array}$ & $\begin{array}{c}{ }^{14} \mathrm{C} \text { Ages } \\
\text { radiocarbon yr B.P. }\end{array}$ \\
\hline SU 1 & $\begin{array}{l}182.19- \\
181.44\end{array}$ & $\begin{array}{l}182.13- \\
181.53\end{array}$ & $\begin{array}{l}182.17- \\
181.44\end{array}$ & $\begin{array}{l}182.13- \\
181.53\end{array}$ & $\begin{array}{c}\text { F3, F4, F5, } \\
\text { F9, F11, F12 }\end{array}$ & $\begin{array}{l}\text { ^A, Ap, Apb, } \\
\text { Ab, Bw, Btb }\end{array}$ & $\begin{array}{l}1375 \pm 30 \text { (ISGS-A0887), } \\
1960 \pm 30 \text { (ISGS-A0893), } \\
2225 \pm 30 \text { (ISGS-A0903), } \\
2885 \pm 30 \text { (ISGS-A0884) }\end{array}$ \\
\hline SU 2 & $\begin{array}{l}181.44- \\
179.59\end{array}$ & $\begin{array}{l}181.53- \\
179.25\end{array}$ & $\begin{array}{l}181.44- \\
179.59\end{array}$ & $\begin{array}{l}181.53- \\
179.37\end{array}$ & $\begin{array}{c}\text { F5, F6, F8, } \\
\text { F12, F13, } \\
\text { F14, F18, } \\
\text { F19, F24 F25, } \\
\text { F27, F28, } \\
\text { F33, F35, } \\
\text { F38, F40 } \\
\end{array}$ & $\mathrm{Btb}, \mathrm{BCb}$ & $\begin{array}{l}2595 \pm 30 \text { (ISGS-A0863), } \\
2855 \pm 30 \text { (ISGS-A0888), } \\
3000 \pm 30 \text { (ISGS-A0861), } \\
3055 \pm 35 \text { (ISGS-A0862), } \\
3105 \pm 30 \text { (ISGS-A0864), } \\
3120 \pm 30 \text { (ISGS-A0892), } \\
4315 \pm 30 \text { (ISGS-A0894) }\end{array}$ \\
\hline SU 3 & $\begin{array}{c}179.59- \\
177.39 \\
\text { BOE }^{a}\end{array}$ & $\begin{array}{c}179.25- \\
178.45 \\
\text { BOE }\end{array}$ & $\begin{array}{l}179.59- \\
177.07\end{array}$ & $\begin{array}{l}179.37- \\
176.42\end{array}$ & $\begin{array}{c}\text { F24, F26, } \\
\text { F44, F45, } \\
\text { F203, F204, } \\
\text { F226 F233, } \\
\text { F246, F256, } \\
\text { F257, F258, } \\
\text { F259 }\end{array}$ & $\mathrm{CBb}$ & $\begin{array}{l}7010 \pm 40 \text { (ISGS-A0860), } \\
7760 \pm 35 \text { (ISGS-A0899), } \\
7825 \pm 40 \text { (ISGS-A0881), } \\
7845 \pm 25 \text { (ISGS-A0868), } \\
7850 \pm 35 \text { (ISGS-A0904), } \\
7910 \pm 35 \text { (ISGS-A0889), } \\
7940 \pm 30 \text { (ISGS-A0869), } \\
7965 \pm 35 \text { (ISGS-A0882), } \\
7985 \pm 30 \text { (ISGS-A0872), } \\
8005 \pm 35 \text { (ISGS-A0900), } \\
8020 \pm 35 \text { (ISGS-A0873), } \\
8025 \pm 35 \text { (ISGS-A0879), } \\
8075 \pm 35 \text { (ISGS-A0902), } \\
8165 \pm 35 \text { (ISGS-A0880), } \\
8215 \pm 35 \text { (ISGS-A0886), } \\
8235 \pm 40 \text { (ISGS-A0870), } \\
8245 \pm 35 \text { (ISGS-A0885), } \\
8265 \pm 35 \text { (ISGS-A0905), } \\
8340 \pm 40 \text { (ISGS-A0906), } \\
8355 \pm 30 \text { (ISGS-A0871), } \\
8360 \pm 50 \text { (ISGS-A0890), } \\
8660 \pm 40 \text { (ISGS-A0883) }\end{array}$ \\
\hline SU 4 & N/A & $\mathrm{N} / \mathrm{A}$ & $\begin{array}{c}177.07- \\
175.17 \\
\text { BOE }\end{array}$ & $\begin{array}{c}176.42- \\
175.17 \\
\text { BOE }\end{array}$ & F255, F260 & $\mathrm{C}$ & N/A \\
\hline
\end{tabular}

${ }^{\mathrm{a}} \mathrm{BOE}=$ base of excavation. 


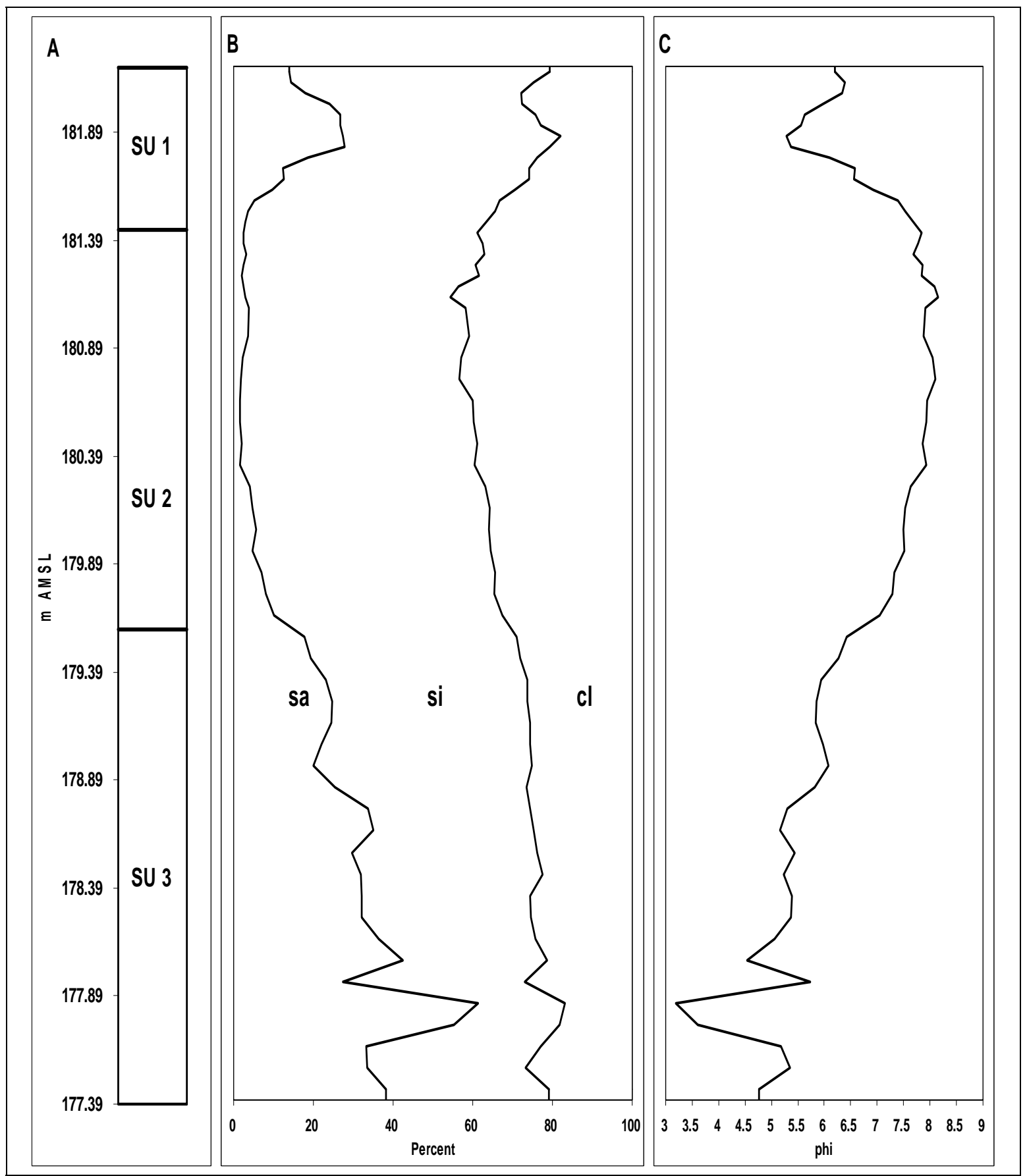

Figure 15: Column 1 sedimentary units (SU) (A), granulometry (B), and mean grain size (phi) (C). Sand (sa) $=-1$ to 4 phi (2.0 to $0.0625 \mathrm{~mm})$; silt (si) $=4$ to 8 phi $(0.0625$ to $0.0039 \mathrm{~mm})$; clay $(\mathrm{cl})=>8$ phi $(<0.0039 \mathrm{~mm})$. 


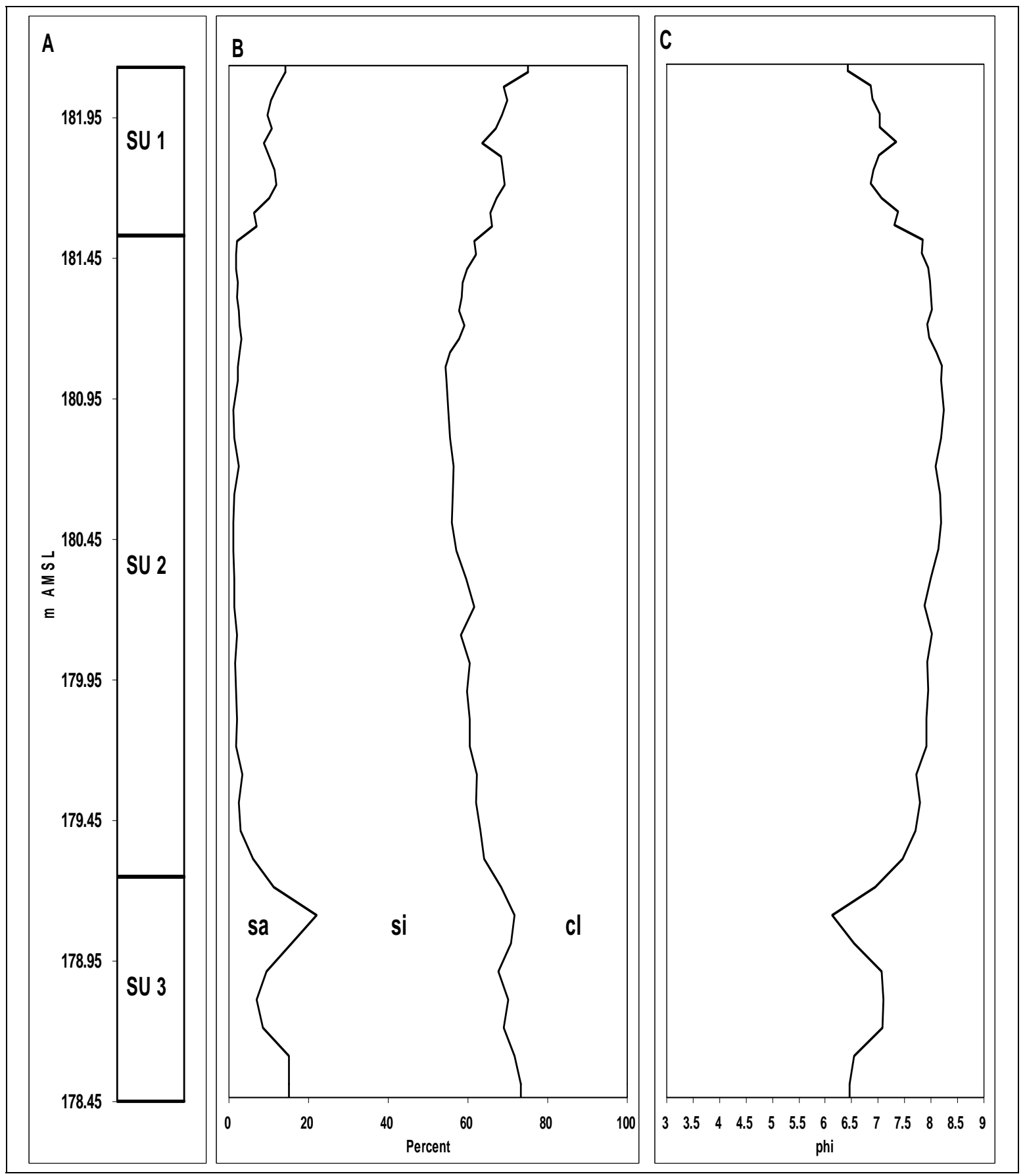

Figure 16: Column 2 sedimentary units (SU) (A), granulometry (B), and mean grain size (phi) (C). Sand (sa) $=-1$ to 4 phi (2.0 to $0.0625 \mathrm{~mm})$; silt (si) $=4$ to 8 phi $(0.0625$ to $0.0039 \mathrm{~mm})$; clay $(\mathrm{cl})=>8 \mathrm{phi}(<0.0039 \mathrm{~mm})$. 
A sedimentary timeframe for SU 1 is inferred from radiocarbon age determinations for samples derived from near the defined base of SU 1 . Three ${ }^{14} \mathrm{C}$ ages for samples from within $\sim 25 \mathrm{~cm}$ above the base of SU 1 in the western portion of the site date to $1960 \pm 30$ B.P. (ISGS-A0893), $2225 \pm 30$ B.P. (ISGS-A0903), and $2885 \pm 30$ B.P. (ISGS-A0884). $\mathrm{A}^{14} \mathrm{C}$ age of $1375 \pm 30$ B.P. (ISGS-A0887) from Feature 64, near the base of SU 1 in the northern portion of Area 1, is the youngest of all 35 West Blennerhassett radiocarbon dates. One sample, ISGS-A0863, recovered from the southwestern portion of Pier 5 at $1 \mathrm{~cm}$ below the base of SU 1 provided a ${ }^{14} \mathrm{C}$ age of 2595 \pm 30 B.P. Samples ISGS-A0892 and ISGS-A0861, from within $20 \mathrm{~cm}$ of the base of SU 1 in Area 1, provided ${ }^{14} \mathrm{C}$ age determinations of $3120 \pm 30$ B.P., and $3000 \pm 30$ B.P., respectively. These ${ }^{14} \mathrm{C}$ ages, all from within $\sim 20 \mathrm{~cm}$ of the base of $\mathrm{SU} 1$, suggest that SU 1 began to accumulate sometime after ca. 3000 B.P.

\section{Sedimentary Unit 2 (SU 2)}

SU 2 is identified between 75 and $260 \mathrm{~cm}$ depth (181.44 and $179.59 \mathrm{~m}$ AMSL) in Column 1 (Figure 15) and between 60 and $288 \mathrm{~cm}$ depth (181.53 and 179.25 m AMSL) in Column 2 (Figure 16). SU 2 was not sampled in the Pier 5 sediment sample columns. SU 2 presumably occurred in the Pier 5 excavation at similar depths as observed in the Deep Test 1 and Deep Test 2 excavations. SU 2 is characterized by fine-textured sediments, very poorly sorted particle-size distribution, and slow sedimentation rates.

A ${ }^{14} \mathrm{C}$ age determination of $7010 \pm 40$ B.P. (ISGS-A0860) from Feature 160 at 263 cm depth (179.57 m AMSL), near the top of underlying SU 3, provides a temporal datum for the onset of SU 2. A ${ }^{14} \mathrm{C}$ age of $4315 \pm 30$ B.P. (ISGS-A0894) from Feature 101 at $134 \mathrm{~cm}$ depth (180.86 m AMSL) provides a temporal datum for the approximate 
middle of SU 2. Radiocarbon ages of $3120 \pm 30$ B.P. (ISGS-A0892), $3105 \pm 30$ B.P. (ISGS- A0864), $3055 \pm 35$ B.P. (ISGS-A0862), and $3000 \pm 30$ B.P. (ISGS-A0861), all associated with cultural features near the top of SU 2 in Area 1 and western Pier 5, strongly suggest that SU 2 was in place by ca. 3000 B.P.

\section{Sedimentary Unit 3 (SU 3)}

The top of SU 3 is identified at $260 \mathrm{~cm}$ depth (179.59 m AMSL) in Column 1 (Figure 15) and at $288 \mathrm{~cm}$ depth (179.25 m AMSL) in Column 2 (Figure 16). The break between SU 2 and SU 3 was not sampled in Columns 3, 4, and 5; these columns appear to have sampled SU 3 sediments exclusively (Figures 17-19). Based on correlation with sediments in Column 1, the surface of SU 3 occurred at 261 cm depth ( 179.59 m AMSL) in the southern portion of Pier 5 and, through correlation with Column 2, 276 cm depth ( 179.37 m AMSL) in the northern portion of Pier 5. The boundary between SU 3 and the underlying SU 4 was not sampled in any of the sediment sample columns; it was exposed only in the deepest portion of the Pier 5 excavation and was marked by a distinct, relatively well-preserved sedimentary bed. The beds that define SU 4 clearly dip towards the north at five percent; where exposed, the base of SU 3 conformably overlies these beds with a parallel northward dip. Accordingly, SU 3 extended to $513 \mathrm{~cm}$ depth (177.07 m AMSL) in the southern extent of its exposure at $\sim \mathrm{N} 430$, and to $578 \mathrm{~cm}$ depth (176.42 m AMSL) in the northern extent of its exposure at $\sim \mathrm{N} 443$.

SU 3 is bracketed by radiocarbon ages of $7010 \pm 40$ B.P. (ISGS-A0860) at $\sim 263$ cm depth (179.57 m AMSL) and $8660 \pm 40$ B.P. (ISGS-A0883) from between $~ 497-515$ cm depth (177.23-177.05 m AMSL). SU 3 is characterized by relatively variable and very poorly sorted particle-size distribution, relatively coarse textures that fine upwards, 


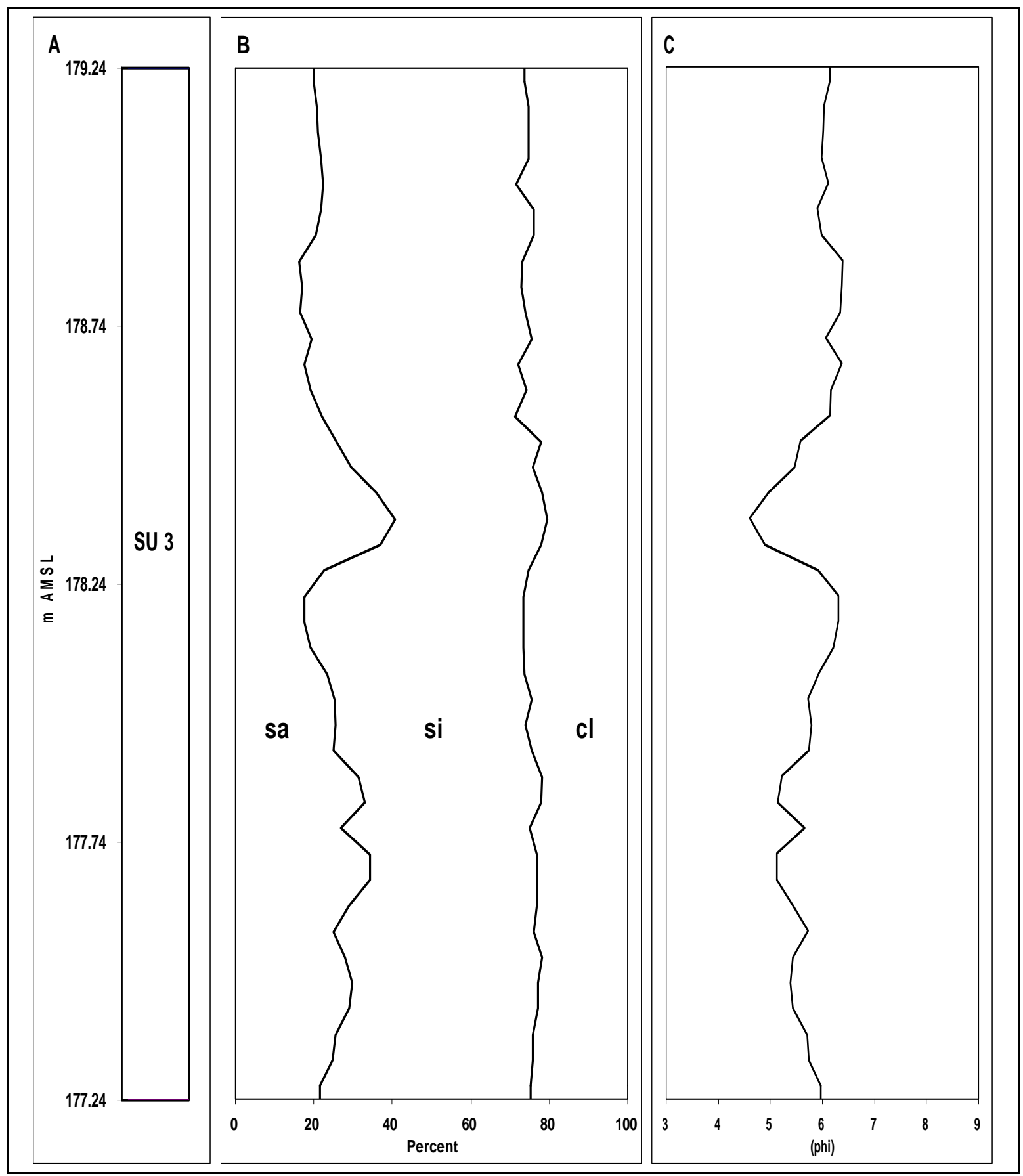

Figure 17: Column 3 sedimentary units (SU) (A), granulometry (B), and mean grain size (phi) (C). Sand (sa) $=-1$ to 4 phi (2.0 to $0.0625 \mathrm{~mm})$; silt (si) $=4$ to 8 phi $(0.0625$ to $0.0039 \mathrm{~mm})$; clay $(\mathrm{cl})=>8$ phi $(<0.0039 \mathrm{~mm})$. 


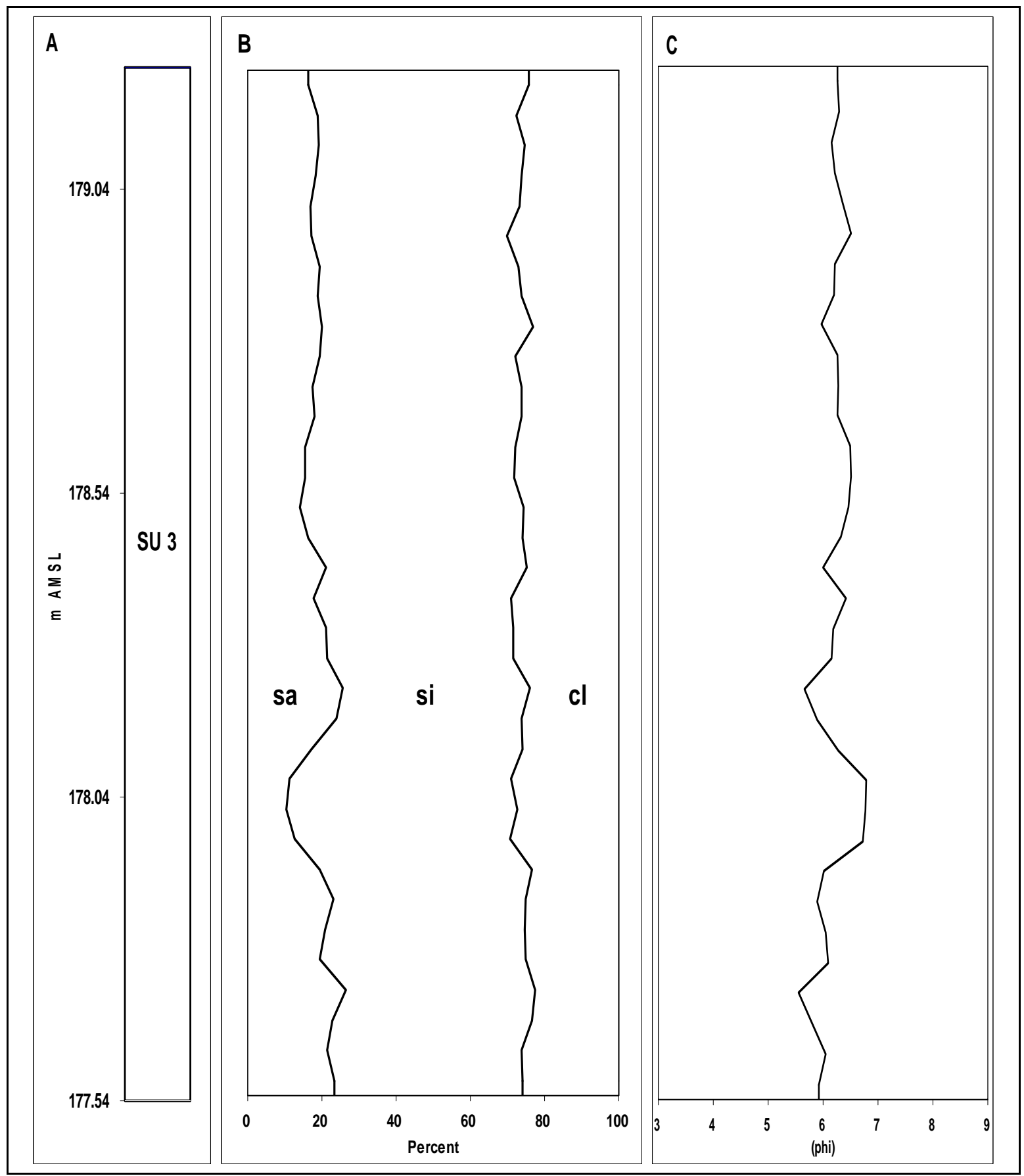

Figure 18: Column 4 sedimentary units (SU) (A), granulometry (B), and mean grain size (phi) (C). Sand (sa) $=-1$ to 4 phi (2.0 to $0.0625 \mathrm{~mm})$; silt (si) $=4$ to 8 phi $(0.0625$ to $0.0039 \mathrm{~mm})$; clay $(\mathrm{cl})=>8 \mathrm{phi}(<0.0039 \mathrm{~mm})$. 


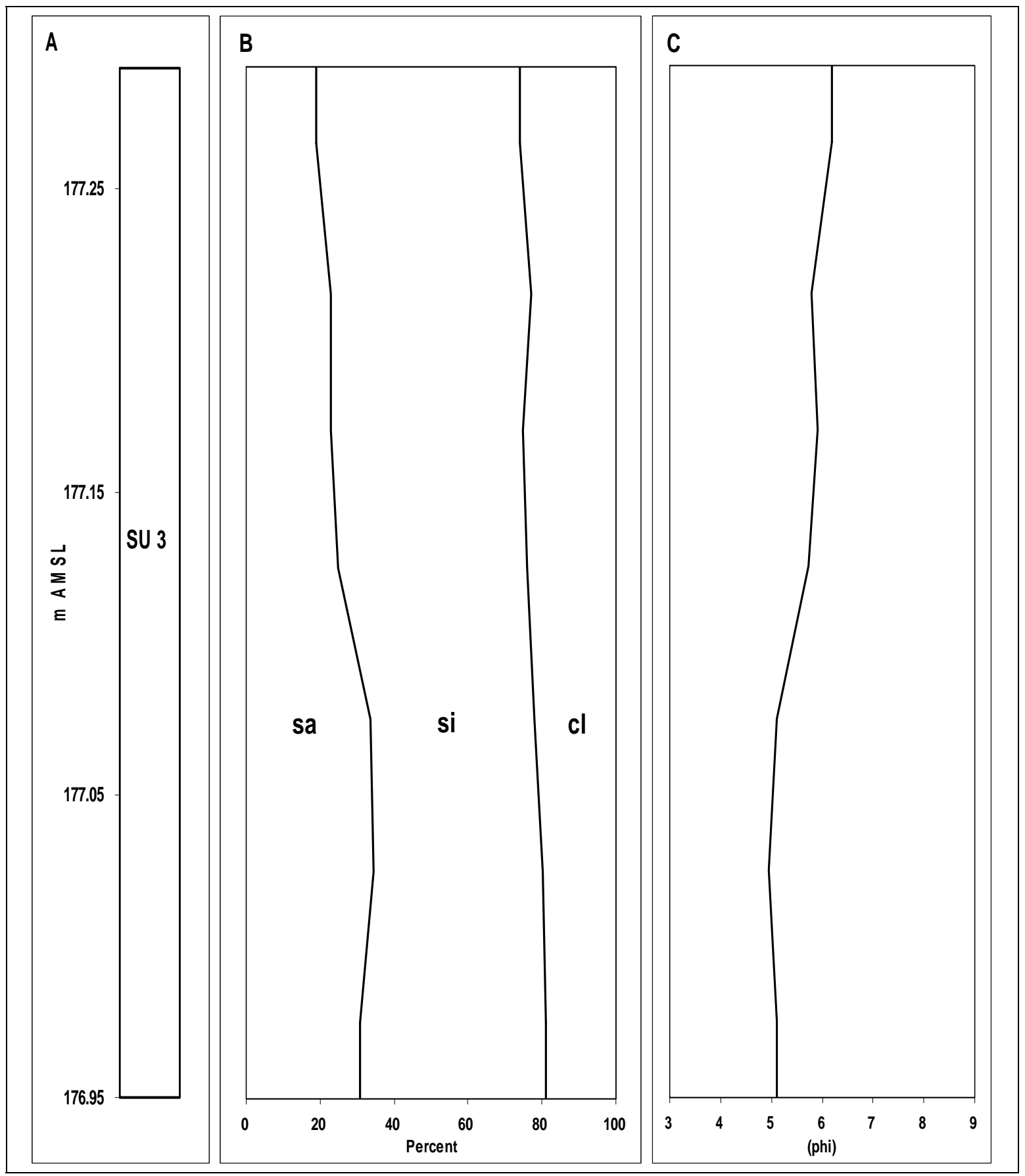

Figure 19: Column 5 sedimentary units (SU) (A), granulometry (B), and mean grain size (phi) (C). Sand (sa) $=-1$ to 4 phi (2.0 to $0.0625 \mathrm{~mm})$; silt (si) $=4$ to 8 phi $(0.0625$ to $0.0039 \mathrm{~mm})$; clay $(\mathrm{cl})=>8 \mathrm{phi}(<0.0039 \mathrm{~mm})$. 
slow to very rapid sedimentation rates, and, in the deepest exposed levels of SU 3, relict depositional features.

SU 3 generally fines upward. However, there is a significant amount variation in mean grain size between textural endpoints (Figures 15-19). This variation is marked by the intermittent deviation of the mean grain size towards decreasing phi values in sediments from Columns 1, 2, 3, and 4. The variation in mean grain size is not as evident in sediments from Column 5 , presumably because the $35 \mathrm{~cm}$-thick sample column was not extensive enough to capture the deviation in sediment textures.

Variations in mean grain size are particularly evident in Column 1 where a $20 \mathrm{~cm}$ thick stratum of relatively unmodified sandy loam sediments between 430 and $450 \mathrm{~cm}$ depth (177.89 and 177.69 m AMSL) are the coarsest sediments identified in the particlesize analysis. This stratum of sandy loam sediments was assigned Field Designation number F44 during excavation of Deep Test 1 (Figure 20) and is referred to as such herein. F44 stood out during excavations as a discrete sandy layer with an abrupt wavy boundary directly overlying a fairly well-preserved Early Archaic period occupation surface. F44 was laterally continuous throughout Deep Test 1 in an areal exposure of approximately $4.5 \mathrm{~m}^{2}$; no analogous sediments were identified in any other sediment sample columns, although Columns 3 and 4 sampled sediments from the same elevation range as F44. Given its apparently limited lateral extent, as well as its distinct textural signature, F44 is interpreted as a splay deposit: a relict depositional feature in the lower depths of SU 3. Other relict depositional features in SU 3 include relatively thin $(<5 \mathrm{~cm})$, laterally discontinuous "lenses” of sandy sediments at Pier 5, many of which dipped northward at five percent. 


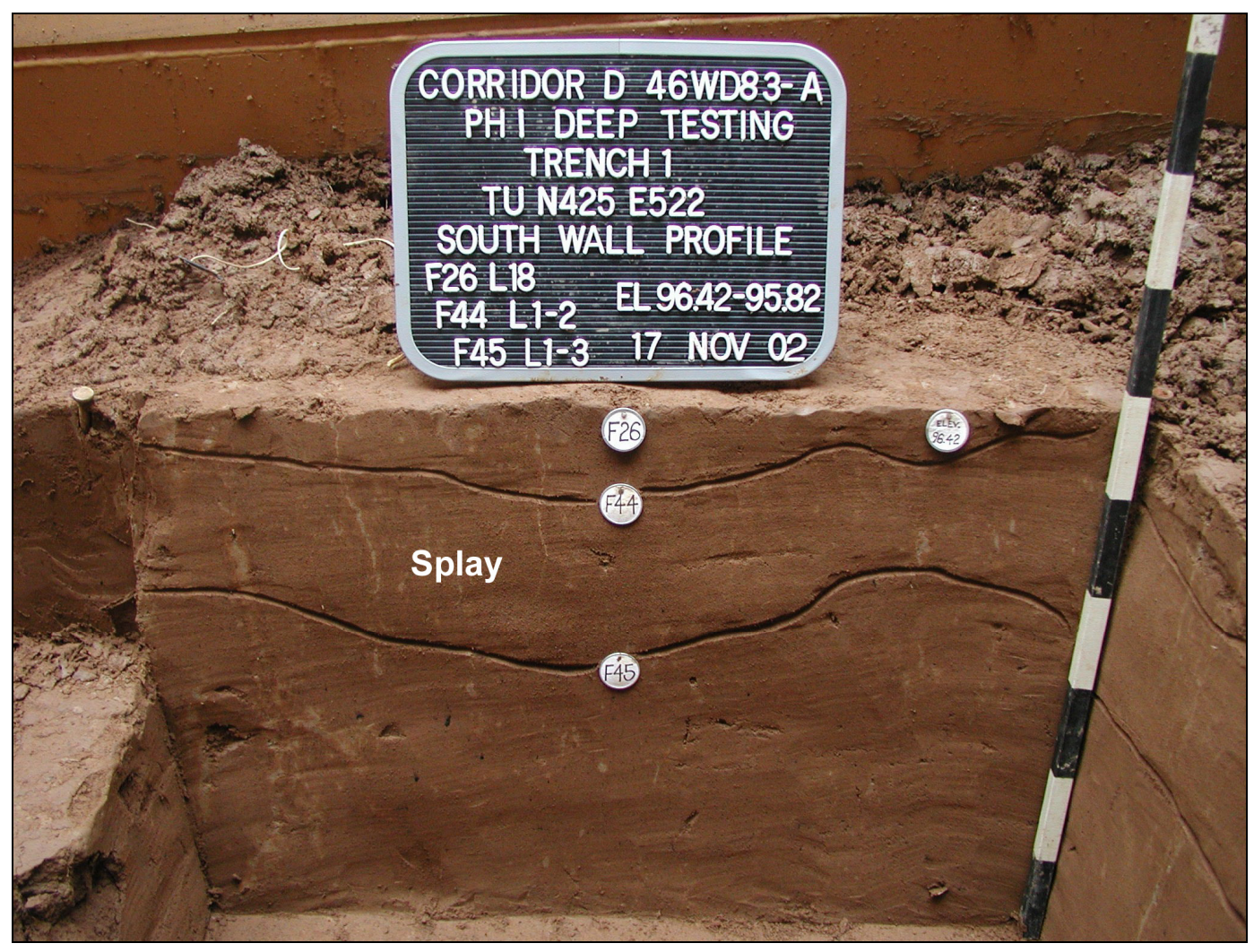

Figure 20: Profile of the south wall of Deep Test 1 (N425 E522) between 420-480 cm depth (177.99-177.39 m AMSL). Scribe marks outline the top and bottom boundaries of the F44 splay deposit. Scale bar is marked in $10 \mathrm{~cm}$ divisions. From Robinson et al. 2008.

\section{Sedimentary Unit 4 (SU 4)}

SU 4 is the deepest sedimentary unit identified at West Blennerhassett. Unlike the other sedimentary units, no sediment samples were obtained from SU 4 in any of the sample columns. Therefore, no particle-size distribution data exist for these sediments. SU 4 was identified and is characterized primarily by the presence of relatively wellpreserved depositional strata: alternating beds of loam and clay loam textured sediments dipping northward at five percent. SU 4 was exposed only in the deepest levels of excavation, below $~ 513 \mathrm{~cm}$ depth ( 177.07 $\mathrm{m}$ AMSL), in the central portion of Pier 5: in the E500 Trench and E500 Trench Extension, and in archaeological test units N436 E492 and N436 E495. The most extensive exposure of SU 4 was in the E500 Trench 
Extension. However, this trench was flooded within minutes of being excavated and remained saturated and unsafe to enter for the remainder of the excavations.

Consequently, time constraints and unsafe conditions in the saturated trench precluded thorough documentation and sampling of SU 4. As such, the description of SU 4 is limited.

The boundaries of SU 4 correlate closely with those of Cultural Stratum VI as well as the C horizon. The break between SU 4 and the overlying SU 3 was rather abrupt; it was delineated to within two cm through identification of the highest laterally continuous unmodified alluvial bed (Figure 21). No radiocarbon age determinations are associated with SU 4. However, several ${ }^{14} \mathrm{C}$ ages associated with samples from near the base of SU 3 suggest that SU 4 was emplaced prior to ca. 8660 B.P.

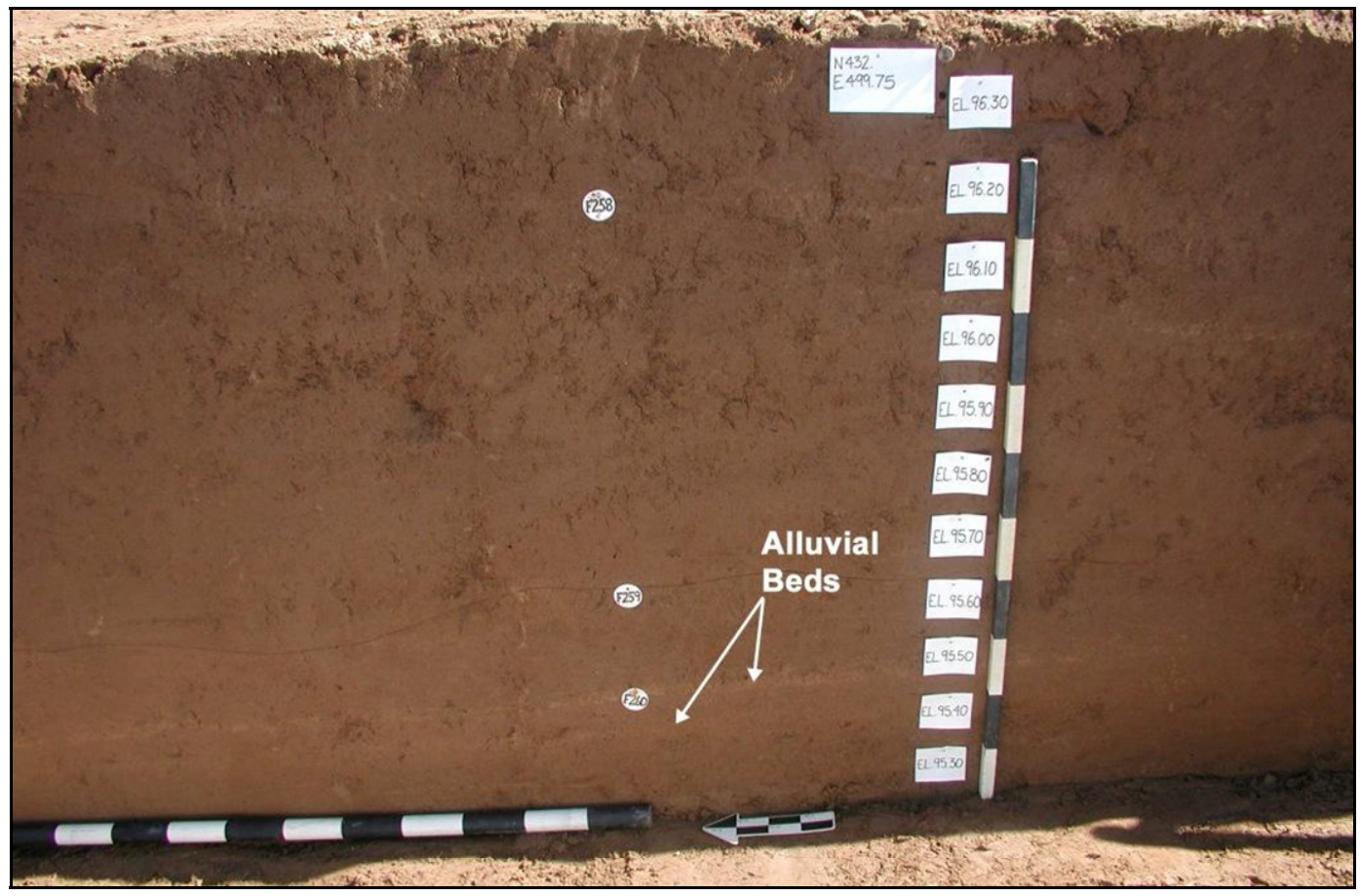

Figure 21: East wall profile of the E500 Trench in Pier 5 showing relatively unaltered alluvial beds (C horizon). The top arrow marks the highest, laterally traceable bed; it also marks the top of SU 4 and CS VI. Bar scales are marked in $10 \mathrm{~cm}$ divisions; north arrow is marked in $5 \mathrm{~cm}$ divisions. Photo taken 8 October 2003. Adapted from Robinson et al. 2008. 


\section{$\underline{\text { Sedimentation Rates }}$}

Sedimentation rates for each of SU 1, SU 2, and SU 3 are presented in Table 4. The sedimentation rates shown in Table 4 represent the minimum and maximum values calculated from a select sample of ${ }^{14} \mathrm{C}$ assays, using two counting errors, associated with the respective sedimentary units. All sedimentation rates presented in Table 4 were calculated using ${ }^{14} \mathrm{C}$ assays associated with features in Pier 5. Three sets of minimum and maximum sedimentation rate values are presented for SU 3: one set from calculations made on ${ }^{14} \mathrm{C}$ assays from near the top and bottom of SU 3, one set from calculations made on ${ }^{14} \mathrm{C}$ assays from the "upper" portion of SU 3, above $178.68 \mathrm{~m}$ AMSL, and one set made on ${ }^{14} \mathrm{C}$ assays from the "lower" portion of SU 3, below 178.70 m AMSL. Further, the sedimentation rates presented in Table 4 are deemed to represent a realistic generalization of the rates of sedimentation for each of the respective sedimentary units. Also, though not shown in Table 4, the F44 splay deposit identified in SU 3 in Deep Test 1 was 20 cm-thick and attests to the potential for large volumes of sediment to have accumulated rapidly, particularly in the depths of SU 3.

In order to facilitate discussion of sedimentation rates in his article "Rates of Fluvial Sedimentation: Implications for Archaeological Variability” Ferring (1986) classified sedimentation rates as such:

$$
\begin{aligned}
& \text { Slow }=<0.1 \mathrm{~cm} \mathrm{yr}^{-1} \\
& \text { Moderate }=0.1-0.5 \mathrm{~cm} \mathrm{yr}^{-1} \\
& \text { Rapid }=0.5-1.0 \mathrm{~cm} \mathrm{yr}^{-1} \\
& \text { Very Rapid }=>1.0 \mathrm{~cm} \mathrm{yr}^{-1}
\end{aligned}
$$

Ferring's classification system is used in this thesis when referring to sedimentation rates. 
Table 4: Sedimentation rates at West Blennerhassett calculated using two counting errors.

\begin{tabular}{|c|c|c|c|c|c|}
\hline SU & $\begin{array}{l}\text { Min. } \\
\text { Rate cm } \\
\text { yr }^{-1}\end{array}$ & $\begin{array}{l}\text { Assays Used to } \\
\text { Calculate Min. } \\
\text { Rate }^{\mathrm{a}} \\
\end{array}$ & $\begin{array}{l}\text { Max. } \\
\text { Rate cm } \\
\text { yr }^{-1}\end{array}$ & $\begin{array}{l}\text { Assays Used to } \\
\text { Calculate Max. } \text { Rate }^{\mathrm{a}} \\
\end{array}$ & $\begin{array}{l}\text { Sedimentation } \\
\text { Rate or Possible } \\
\text { Rate Range }\end{array}$ \\
\hline SU 1 & 0.02 & $\begin{array}{l}\text { ISGS-A0884 and } \\
\text { GS }^{\text {b }}\end{array}$ & 0.04 & $\begin{array}{l}\text { ISGS-A0887 and } \\
\text { GS }^{\mathrm{c}}\end{array}$ & Slow \\
\hline SU 2 & 0.03 & $\begin{array}{l}\text { ISGS-A0864 and } \\
\text { ISGS-A0894 }\end{array}$ & 0.04 & $\begin{array}{l}\text { ISGS-A0892 and } \\
\text { ISGS -A0894 }\end{array}$ & Slow \\
\hline SU 3 & 0.10 & $\begin{array}{l}\text { ISGS-A0860 and } \\
\text { ISGS-A0880 }\end{array}$ & 0.22 & $\begin{array}{l}\text { ISGS-A0860 and } \\
\text { ISGS -A0886 }\end{array}$ & Moderate \\
\hline $\begin{array}{l}\text { Upper } \\
\text { SU } 3 \\
\end{array}$ & 0.07 & $\begin{array}{l}\text { ISGS-A0860 and } \\
\text { ISGS -A0902 }\end{array}$ & 0.15 & $\begin{array}{l}\text { ISGS-A0860 and } \\
\text { ISGS -A0899 }\end{array}$ & Slow-Moderate \\
\hline $\begin{array}{l}\text { Lower } \\
\text { SU } 3 \\
\end{array}$ & 0.09 & $\begin{array}{l}\text { ISGS-A0880 and } \\
\text { ISGS -A0899 }\end{array}$ & 10.00 & $\begin{array}{l}\text { ISGS-A0873 and } \\
\text { ISGS -A0880 }\end{array}$ & Slow-Very Rapid \\
\hline
\end{tabular}

${ }^{\mathrm{a}}$ ISGS lab number or ground surface (GS).

b 2002 ground surface at 182.20 m AMSL.

c 2003 ground surface at 182.13 m AMSL.

\section{Pedology}

Soils at the West Blennerhassett site are mapped as Huntington fine sandy loam (Ellyson et al. 1970; Soil Survey Staff 2008a) (Figure 22). Small areas of Lindside silt loam are mapped at the southwestern and east-central portions of the study area (Ellyson et al. 1970; Soil Survey Staff 2008a) (Figure 22). However, Lindside series soils were not identified in the archeological excavations, so they are given no further consideration herein. Huntington series soils are Fluventic Hapludolls (Soil Survey Staff 2008b). The subgroup designation Fluventic indicates that the Huntington series soils grade towards Fluvents, alluvial soils with simple profiles and organic matter content that varies irregularly with depth (Boul et al. 2003). The great group formative element, Hapl, connotes that the soil has the minimum properties required to meet the specifications of the Udolls suborder. The suborder formative element, ud, indicates that the soil formed in an udic soil moisture regime, a moisture regime associated with humid climates. The soil order formative element, olls, indicates that the soil belongs to the Mollisol order, an 
order characterized by a mollic epipedon, a relatively thick surface horizon that is dark in color with relatively high organic carbon and soluble phosphate content and high base saturation (Boul et al. 2003).

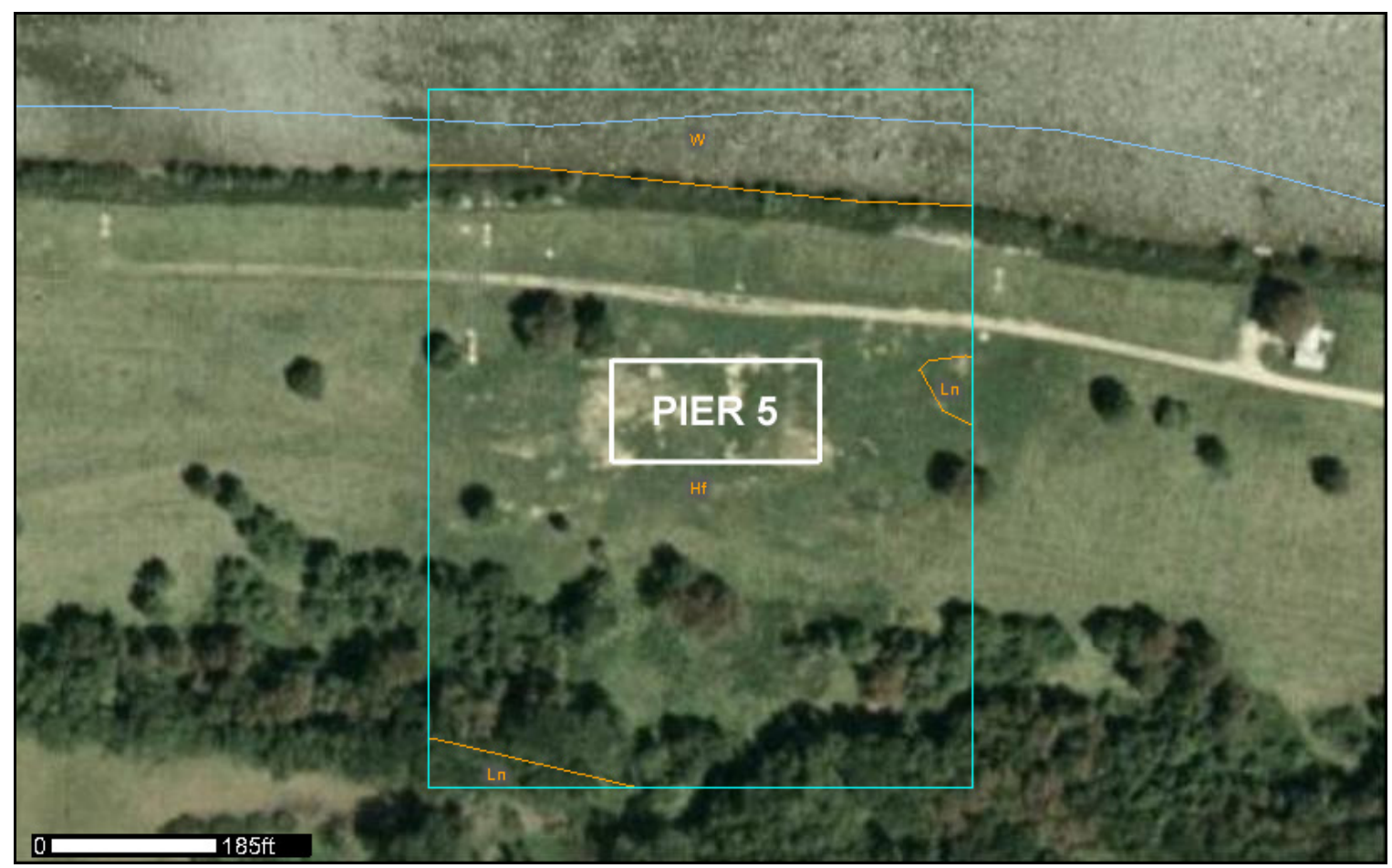

Figure 22: NRCS Web Soil Survey image of the site area (adapted from Soil Survey Staff 2008a) showing soil series designations and the approximate location of Pier 5 . Hf = Huntington fine sandy loam, $\mathrm{Ln}=$ Lindside silt loam, $\mathrm{W}=$ water.

In the absence of specific laboratory chemical analyses it is difficult to state with confidence if the West Blennerhassett soils meet criteria to qualify as having a mollic epipedon by Soil Survey Staff (1999) standards, particularly those that pertain to organic carbon and soluble phosphate content and base saturation. Field observations, however, indicate that West Blennerhassett soils generally meet mollic epipedon criteria for ped structure, color, and epipedon thickness.

In a more general sense, it can be said that a cumulative soil has developed at West Blennerhassett. Cumulative soils can result from cumulization, the upward growth 
of a horizon due to incremental addition of alluvium and pedogenic incorporation of added sediments (Birkeland 1999; Nikiforoff 1949; Schaetzl and Anderson 2005). Birkeland (1999), Nikiforoff (1949), and Schaetzl and Anderson (2005) all note that the transformation of an A horizon to a B horizon through upward growth of the B horizon is a characteristic of cumulative soils; this is arguably the case at West Blennerhassett.

\section{$\underline{\text { Soil Profiles }}$}

The soil profiles in Deep Test 1, Deep Test 2, Area 1, and Pier 5 were remarkably similar to one another. Most of the variation between the soil profiles occurred within the uppermost $60-80 \mathrm{~cm}$ at the excavation areas. Each of the various sequences of soil horizons in the upper portions of the profiles was continuous across laterally extensive portions of the site (Figure 23). A generalized west-facing profile of soil horizons in Deep Test 1, Deep Test 2, and Pier 5 is shown in Figure 24. Profile descriptions for each of Deep Test 1, Deep Test 2, Area 1, and southern Pier 5 are provided in Tables 5 through 8.

The soil profiles across most of Deep Tests 1 and 2, Area 1, and Pier 5 were capped by an $\wedge$ A horizon, a mineral horizon of human-transported materials. The $\wedge \mathrm{A}$ horizon appeared to be a mixture of topsoil and subsoil spoil associated with excavations for subterranean utilities that transect the northern and central portions of the site. Where present, the $\wedge \mathrm{A}$ horizon was underlain by an Apb horizon (buried plow zone) (Figure 25). The $\wedge$ A horizon was not present in the central portion of Area 1 and the west-central portion of Pier 5; an Ap horizon occurred at the ground surface in these areas (Figure 26). The Ap and Apb horizon were essentially the same entity but were assigned separate horizon designations due to the occurrence of the $\wedge$ A horizon overlying the Apb horizon. 
Both the Ap and Apb horizons contained a mix of historic and prehistoric artifacts and exhibited abrupt smooth boundaries with underlying horizons.

In Deep Test 1, Deep Test 2, and the easternmost 2/3 of Pier 5, the Apb horizon was underlain by an argillic Btb horizon, a mineral horizon that has an increase in clay from the overlying eluvial horizon and exhibits evidence of clay illuviation. In southern Area 1 and southwestern Pier 5 the upper portion of the soil profile was characterized with an $\wedge \mathrm{A}-\mathrm{Apb}-\mathrm{Ab}$ horizon sequence overlying a Btb horizon. The upper portion of the soil profile in northern Area 1 and northwestern Pier 5 consisted of an $\wedge$ A-Apb-Bwb-Ab horizon sequence overlying a Btb horizon.

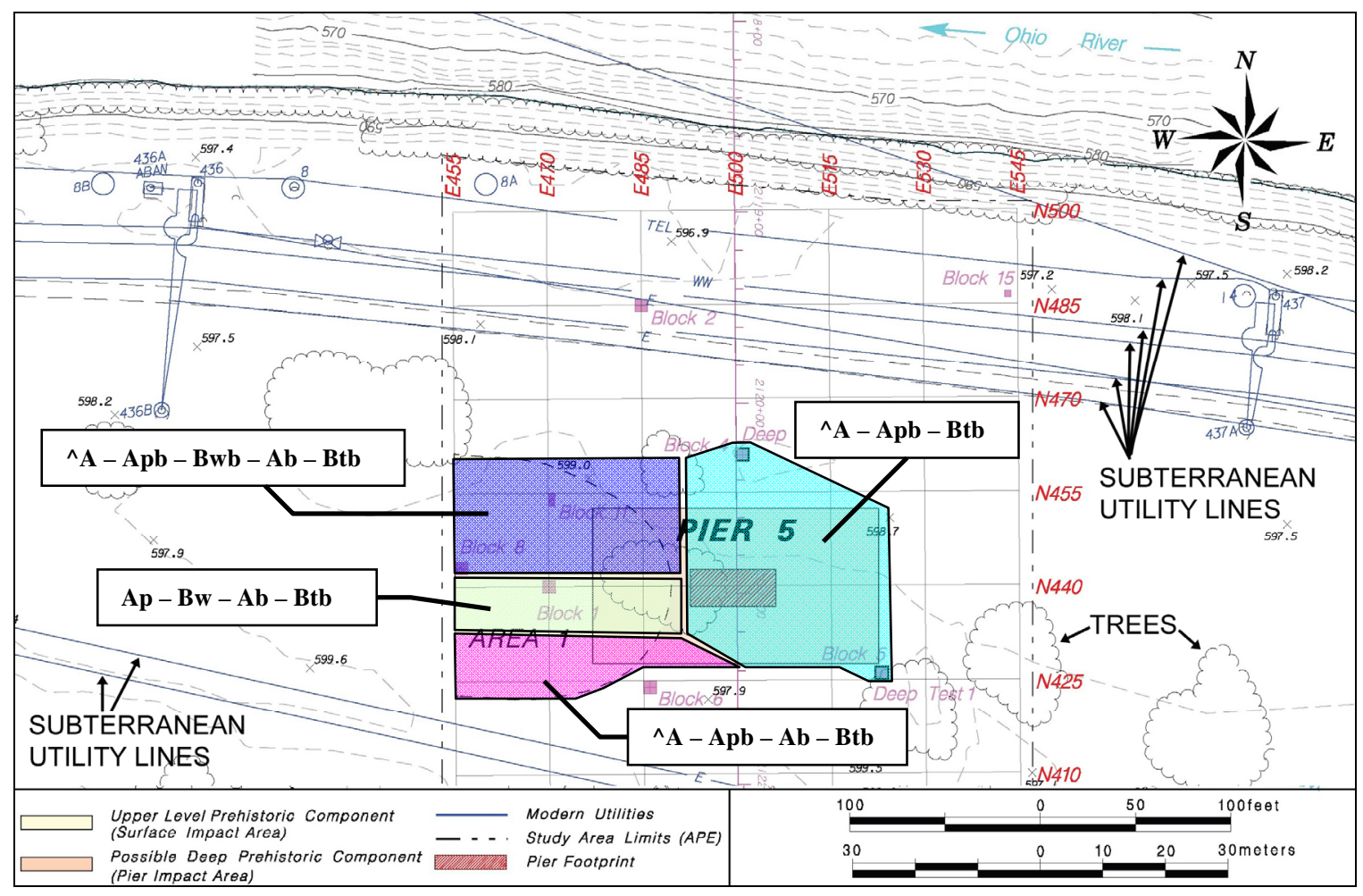

Figure 23: Map of the northern portion of West Blennerhassett, showing the distribution of soil horizons in the upper profiles of Deep Test 1, Deep Test 2, Area 1, and Pier 5. 


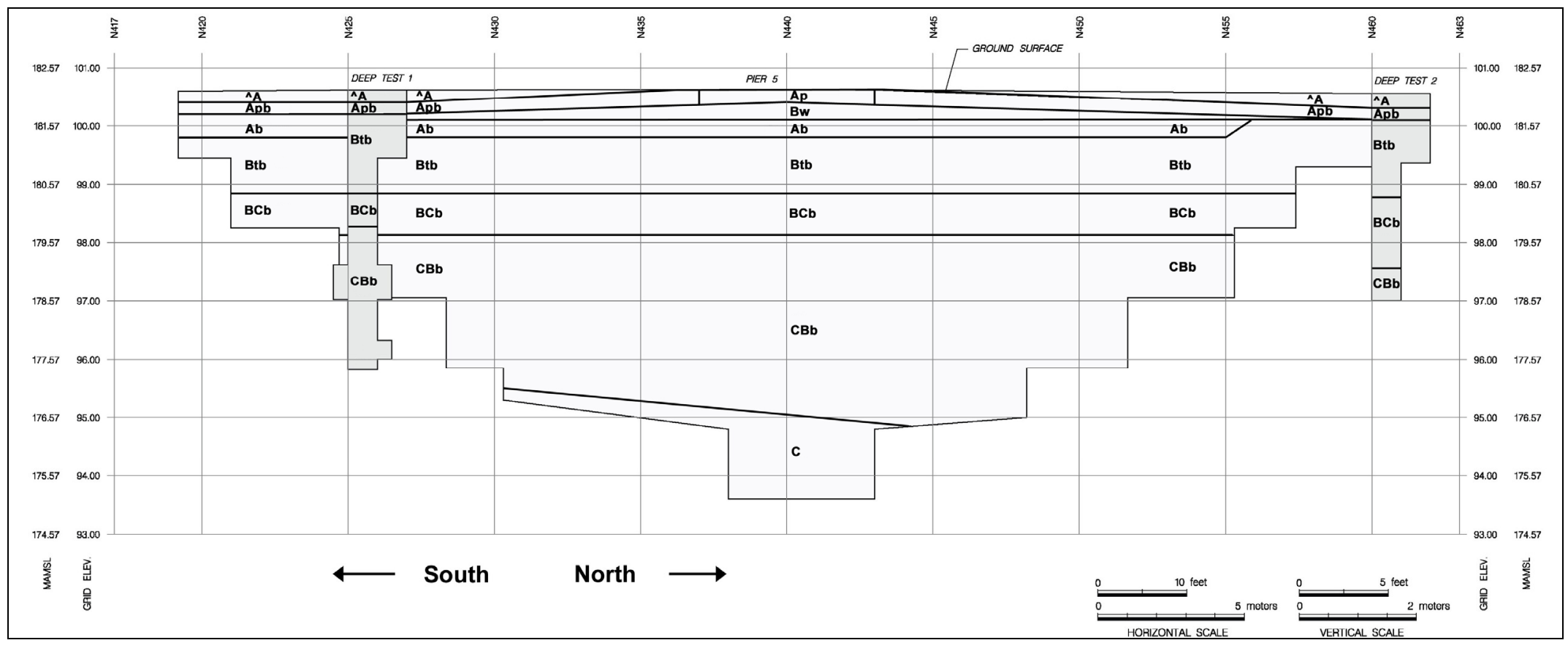

Figure 24: Generalized profile of Deep Test 1, Deep Test 2, and Pier 5 facing downriver (west) and showing soil horizons with vertical exaggeration of 2. 
Table 5: Soil horizons in Deep Test 1.

\begin{tabular}{|c|c|c|c|c|}
\hline $\begin{array}{c}\text { Soil } \\
\text { Horizon }\end{array}$ & $\begin{array}{c}\text { Field } \\
\text { Designation } \\
(\mathrm{F \# )} \\
\end{array}$ & Description & $\begin{array}{l}\text { Depth } \\
\text { (cm) }\end{array}$ & Comments \\
\hline$\wedge \mathrm{A}$ & F3 & $\begin{array}{l}\text { dark yellowish brown (10YR } 3 / 4) \text { silt } \\
\text { loam, moderate medium granular } \\
\text { structure, clear smooth boundary }\end{array}$ & $0-17$ & $\begin{array}{l}\text { The ^^A horizon appears to be } \\
\text { human-transported sediment } \\
\text { associated with excavation for } \\
\text { subterranean utility lines. The }{ }^{\wedge} \mathrm{A} \\
\text { horizon contained a mix of historic } \\
\text { and prehistoric period artifacts. }\end{array}$ \\
\hline Apb & $\mathrm{F} 4$ & $\begin{array}{l}\text { dark brown (10YR } 3 / 3) \text { silt loam, } \\
\text { moderate coarse granular structure, } \\
\text { abrupt smooth boundary }\end{array}$ & $17-40$ & $\begin{array}{l}\text { The Apb (plow zone) contained a } \\
\text { mix of prehistoric and historic } \\
\text { period artifacts. }\end{array}$ \\
\hline Btb & F5 & $\begin{array}{l}\text { dark yellowish brown (10YR } 3 / 4) \text { silty } \\
\text { clay loam, moderate medium and } \\
\text { coarse subangular blocky structure, } \\
\text { with clay coatings on ped surfaces }\end{array}$ & $40-180$ & $\begin{array}{l}\text { Ped size and expression varied } \\
\text { with depth in the Btb horizon. } \\
\text { However, subdivisions of the Btb } \\
\text { horizon (e.g. Btb1, Btb2) were not } \\
\text { recorded. }\end{array}$ \\
\hline $\mathrm{BCb}$ & F24 & $\begin{array}{l}\text { dark yellowish brown (10YR 3/6) silty } \\
\text { clay loam, weak to moderate medium } \\
\text { and coarse subangular blocky structure, } \\
\text { brown (10YR } 5 / 3 \text { ) clay coatings on } \\
\text { peds, with common, coarse to very } \\
\text { coarse, distinct, grayish brown (10YR } \\
5 / 2 \text { ) redox depletions }\end{array}$ & $\begin{array}{l}180- \\
235\end{array}$ & $\begin{array}{l}\text { Ped size and expression varied } \\
\text { with depth in the } \mathrm{BCb} \text { horizon. } \\
\text { However, subdivisions of the } \mathrm{BCb} \\
\text { horizon (e.g. BCb1, BCb2) were } \\
\text { not recorded. }\end{array}$ \\
\hline $\mathrm{CBb}$ & F26 & $\begin{array}{l}\text { dark yellowish brown (10YR } 3 / 4 \text { and } \\
10 Y R \text { 4/4) loam and silt loam, weak } \\
\text { medium subangular blocky structure, } \\
\text { with common, coarse to very coarse, } \\
\text { distinct, grayish brown (10YR 5/2) } \\
\text { redox depletions }\end{array}$ & $\begin{array}{l}235- \\
480+\end{array}$ & $\begin{array}{l}\text { Ped size and expression varied } \\
\text { with depth in the CBb horizon. } \\
\text { However, subdivisions of the CBb } \\
\text { horizon (e.g. CBb1, CBb2) were } \\
\text { not recorded. }\end{array}$ \\
\hline
\end{tabular}

Table 6: Soil horizons in Deep Test 2.

\begin{tabular}{|c|c|c|c|c|}
\hline $\begin{array}{c}\text { Soil } \\
\text { Horizon }\end{array}$ & $\begin{array}{c}\text { Field } \\
\text { Designation } \\
(\mathrm{F \# )}\end{array}$ & Description & $\begin{array}{c}\text { Depth } \\
\text { (cm) }\end{array}$ & Comments \\
\hline$\wedge \mathrm{A}$ & F3 & $\begin{array}{l}\text { dark yellowish brown (10YR 3/4) silt } \\
\text { loam, moderate medium granular } \\
\text { structure, clear smooth boundary }\end{array}$ & $0-35$ & $\begin{array}{l}\text { The } \wedge^{\wedge} \text { horizon appears to be } \\
\text { human-transported sediment } \\
\text { associated with excavation for } \\
\text { subterranean utility lines. The }{ }^{\wedge} \mathrm{A} \\
\text { horizon contained a mix of historic } \\
\text { and prehistoric period artifacts. }\end{array}$ \\
\hline Apb & F4 & $\begin{array}{l}\text { dark brown (10YR } 3 / 3) \text { silt loam, } \\
\text { moderate coarse granular structure, } \\
\text { abrupt smooth boundary }\end{array}$ & $35-58$ & $\begin{array}{l}\text { The Apb (plow zone) contained a } \\
\text { mix of prehistoric and historic } \\
\text { period artifacts. }\end{array}$ \\
\hline Btb & F5 & $\begin{array}{l}\text { dark yellowish brown (10YR } 3 / 4) \text { silty } \\
\text { clay loam, moderate medium and } \\
\text { coarse subangular blocky structure, } \\
\text { with clay coatings on ped surfaces }\end{array}$ & $58-178$ & $\begin{array}{l}\text { Ped size and expression varied } \\
\text { with depth in the Btb horizon. } \\
\text { However, subdivisions of the Btb } \\
\text { horizon (e.g. Btb1, Btb2) were not } \\
\text { recorded. }\end{array}$ \\
\hline $\mathrm{BCb}$ & F24 & $\begin{array}{l}\text { dark yellowish brown (10YR 3/6) silty } \\
\text { clay loam, weak to moderate medium } \\
\text { and coarse subangular blocky structure, } \\
\text { brown (10YR 5/3) clay coatings on } \\
\text { peds, with common, coarse to very } \\
\text { coarse, distinct, grayish brown (10YR } \\
5 / 2 \text { ) redox depletions }\end{array}$ & $\begin{array}{l}178- \\
298\end{array}$ & $\begin{array}{l}\text { Ped size and expression varied } \\
\text { with depth in the BCb horizon. } \\
\text { However, subdivisions of the } \mathrm{BCb} \\
\text { horizon (e.g. } \mathrm{BCb} 1, \mathrm{BCb} 2) \text { were } \\
\text { not recorded. }\end{array}$ \\
\hline $\mathrm{CBb}$ & F26 & $\begin{array}{l}\text { dark yellowish brown (10YR 3/4 and } \\
10 Y R \text { 4/4) loam and silt loam, weak } \\
\text { medium subangular blocky structure, } \\
\text { with common, coarse to very coarse, } \\
\text { distinct, grayish brown (10YR 5/2) } \\
\text { redox depletions }\end{array}$ & $\begin{array}{l}298- \\
368+\end{array}$ & $\begin{array}{l}\text { Ped size and expression varied } \\
\text { with depth in the CBb horizon. } \\
\text { However, subdivisions of the CBb } \\
\text { horizon (e.g. CBb1, CBb2) were } \\
\text { not recorded. }\end{array}$ \\
\hline
\end{tabular}


Table 7: Soil horizons at N440.00 E470.00 in Block 1 (Phase II)/Area 1 (Phase III).

\begin{tabular}{|c|c|c|c|c|}
\hline $\begin{array}{c}\text { Soil } \\
\text { Horizon }\end{array}$ & $\begin{array}{c}\text { Field } \\
\text { Designation } \\
(\mathrm{F} \#) \\
\end{array}$ & Description & $\begin{array}{l}\text { Depth } \\
\text { (cm) }\end{array}$ & Comments \\
\hline Ap & $\mathrm{F} 4$ & $\begin{array}{l}\text { dark brown (10YR } 3 / 3) \text { silt } \\
\text { loam, moderate coarse } \\
\text { granular structure, abrupt } \\
\text { smooth boundary }\end{array}$ & $0-17$ & $\begin{array}{l}\text { The Ap (plow zone) contained a mix of } \\
\text { prehistoric and historic period artifacts. }\end{array}$ \\
\hline Bw & F40 & $\begin{array}{l}\text { dark yellowish brown (10YR } \\
\text { 3/4) silty clay loam, moderate } \\
\text { medium subangular blocky } \\
\text { structure }\end{array}$ & $17-43$ & $\begin{array}{l}\text { The Bw horizon was identified directly } \\
\text { below the Ap horizon in Area } 1 \text { and western } \\
\text { Pier } 5 .\end{array}$ \\
\hline$A b$ & $\begin{array}{l}\text { F12, F18, F25, } \\
\text { F33 }\end{array}$ & $\begin{array}{l}\text { dark brown (10YR } 3 / 3 \text { ) silty } \\
\text { clay loam, moderate medium } \\
\text { subangular blocky structure }\end{array}$ & $43-63$ & $\begin{array}{l}\text { The Ab horizon appears to be } \\
\text { anthropogenically modified. }\end{array}$ \\
\hline Btb & F19 & $\begin{array}{l}\text { dark yellowish brown (10YR } \\
3 / 4) \text { silty clay loam, moderate } \\
\text { medium and coarse } \\
\text { subangular blocky structure, } \\
\text { with clay coatings on ped } \\
\text { surfaces }\end{array}$ & $\begin{array}{c}63- \\
120+\end{array}$ & $\begin{array}{l}\text { Excavation in the western } \sim 2 / 3 \text { of Area } 1 \\
\text { was halted in the Btb horizon. Ped size and } \\
\text { expression varied with depth in the Btb } \\
\text { horizon. However, subdivisions of the Btb } \\
\text { horizon (e.g. Btb1, Btb2) were not recorded. }\end{array}$ \\
\hline
\end{tabular}

Table 8: Soil horizons at N439.37 E506.30 along the south wall of Pier 5.

\begin{tabular}{|c|c|c|c|c|}
\hline $\begin{array}{c}\text { Soil } \\
\text { Horizon }\end{array}$ & $\begin{array}{c}\text { Field } \\
\text { Designation } \\
(\mathrm{F} \#)\end{array}$ & Description & $\begin{array}{l}\text { Depth } \\
\text { (cm) }\end{array}$ & Comments \\
\hline${ }^{\wedge} \mathrm{A}$ & F3 & $\begin{array}{l}\text { dark yellowish brown } \\
(10 Y R \text { Y/4) silt loam, } \\
\text { moderate medium } \\
\text { granular structure, clear } \\
\text { smooth boundary }\end{array}$ & $0-8$ & $\begin{array}{l}\text { The }{ }^{\wedge} \mathrm{A} \text { horizon appears to be human-transported } \\
\text { sediment associated with excavation for } \\
\text { subterranean utility lines. The } \wedge^{\wedge} \text { horizon } \\
\text { contained a mix of historic and prehistoric period } \\
\text { artifacts. }\end{array}$ \\
\hline Apb & F4 & $\begin{array}{l}\text { dark brown (10YR 3/3) } \\
\text { silt loam, moderate } \\
\text { coarse granular } \\
\text { structure, abrupt smooth } \\
\text { boundary }\end{array}$ & $8-47$ & $\begin{array}{l}\text { The Apb (plow zone) contained a mix of } \\
\text { prehistoric and historic period artifacts. }\end{array}$ \\
\hline$A b$ & F28 & $\begin{array}{l}\text { dark brown (10YR } 3 / 3) \\
\text { and dark yellowish } \\
\text { brown }(10 Y \mathrm{Y} 3 / 4) \text { silty } \\
\text { clay loam, moderate } \\
\text { medium subangular } \\
\text { blocky structure, gradual } \\
\text { wavy boundary }\end{array}$ & $47-65$ & $\begin{array}{l}\text { The Ab horizon appears to be anthropogenically } \\
\text { modified. }\end{array}$ \\
\hline Btb & F5 & $\begin{array}{l}\text { dark yellowish brown } \\
\text { (10YR 3/4) silty clay } \\
\text { loam, moderate medium } \\
\text { and coarse subangular } \\
\text { blocky structure, with } \\
\text { clay coatings on ped } \\
\text { surfaces }\end{array}$ & $\begin{array}{c}65- \\
120+\end{array}$ & $\begin{array}{l}\text { The pedon description at this location was } \\
\text { terminated at } 120 \mathrm{~cm} \text {. However, Excavation of } \\
\text { Pier } 5 \text { continued to } 500+\mathrm{cm} \text {. BCb and CBb } \\
\text { horizons, similar to those in Deep Tests } 1 \text { and } 2 \text {, } \\
\text { occurred below the Btb horizon in Pier } 5 \text {. Ped } \\
\text { size and expression varied with depth in the Btb } \\
\text { horizon. However, subdivisions of the Btb } \\
\text { horizon (e.g. Btb1, Btb2) were not recorded. }\end{array}$ \\
\hline
\end{tabular}




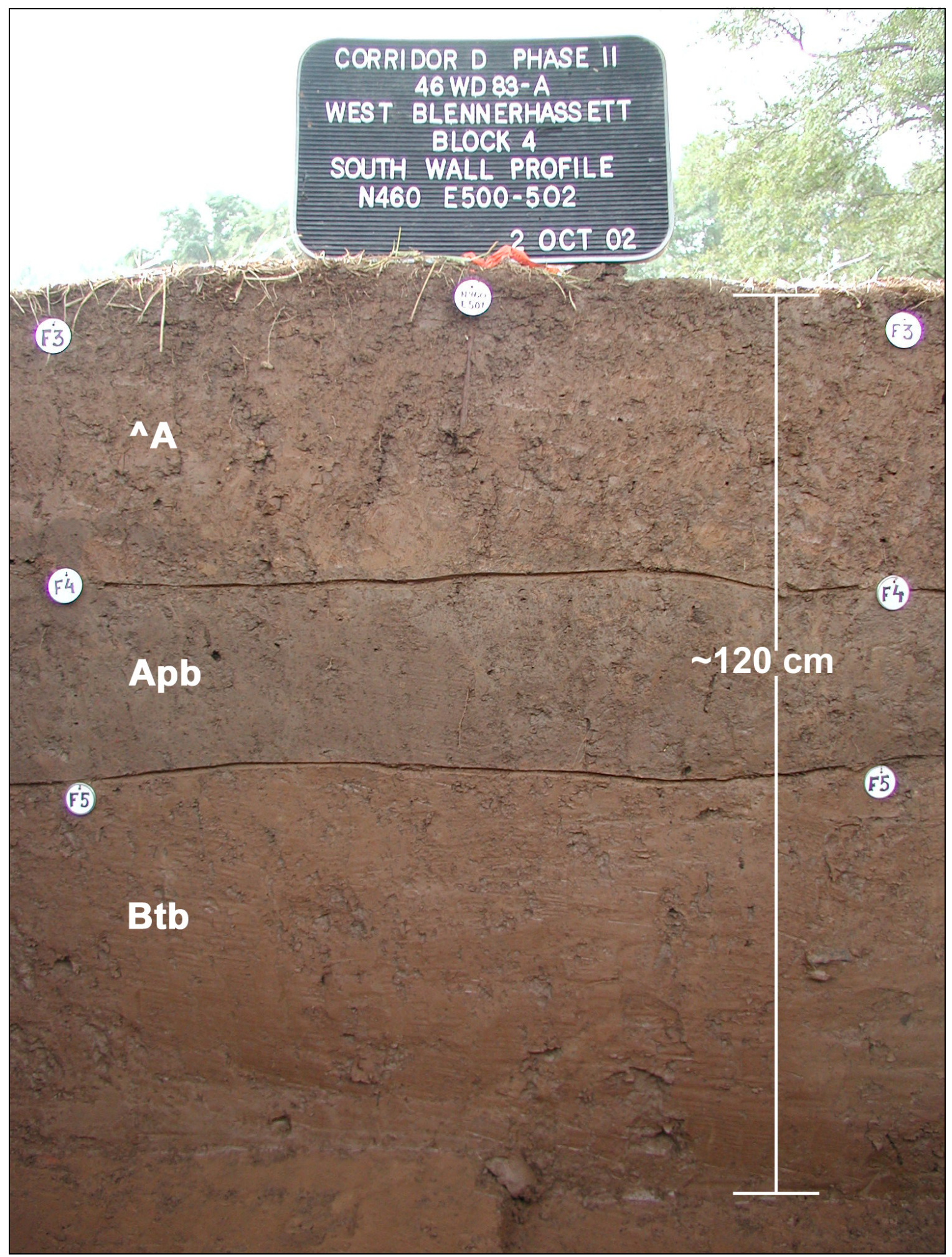

Figure 25: Profile of the south wall of Block 4 (a.k.a. Deep Test 2). Scribes and circular tags mark the breaks between the $\wedge \mathrm{A}, \mathrm{Apb}$, and Btb horizons. 


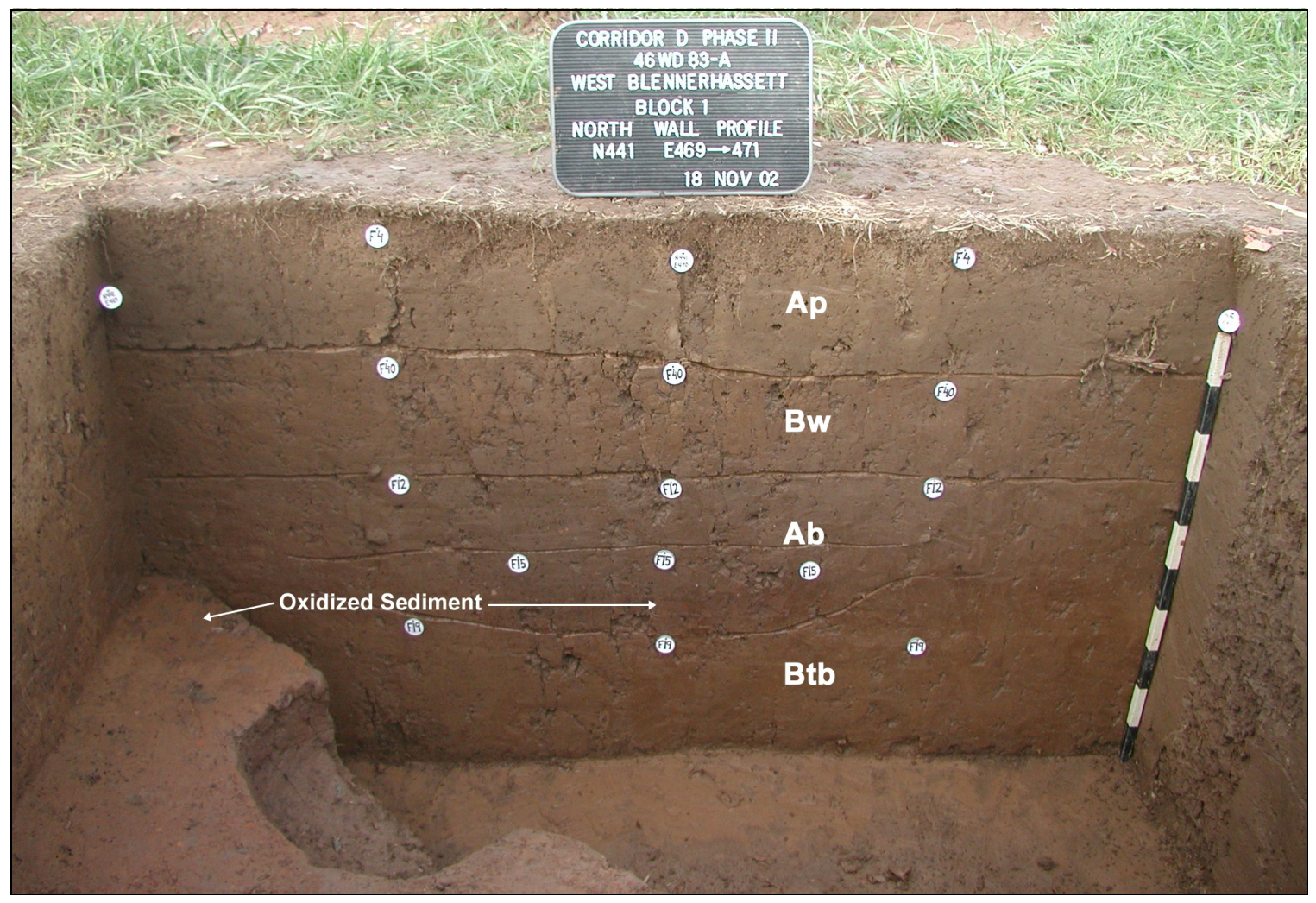

Figure 26: North wall profile of Phase II Block 1 excavation. Scribes and circular tags mark the breaks between soil horizons and anthropogenic features. Scale bar is marked in $10 \mathrm{~cm}$ divisions. Block 1 was located in the central portion of the Phase III excavation at Area 1 . Scale bar is marked in $10 \mathrm{~cm}$ divisions.

The soil profile in central Area 1 and west-central Pier 5 was similar to the profile in northern Area 1 and northwestern Pier 5, except for the presence of the $\wedge$ A horizon at the ground surface. The upper profile in central Area 1 and west-central Pier 5 consisted of an Ap-Bw-Ab horizon sequence overlying a Btb horizon (Figure 26).

The Ab horizon in Area 1 and western Pier 5 was characterized by a relatively dark (dark brown: 10YR 3/3) matrix color, dense concentrations of cultural features, high volumes of artifacts, and inclusions of anthropogenically-modified sediments including wood charcoal, carbonized nutshell, and oxidized sediments. These characteristics indicate that the Ab horizon developed, in part, as a result of human occupation at the site. 
The sequence of subsoil horizons below 60-80 cm was consistent between Deep Test 1, Deep Test 2, and Pier 5. Excavation in Area 1 was halted in the Btb horizon at $120 \mathrm{~cm}$ depth. In Deep Test 1, Deep Test 2, and Pier 5 the profiles consisted of a Btb-BCb-CBb horizon sequence. Transitions within and between the Btb, $\mathrm{BCb}$, and $\mathrm{CBb}$ horizons were gradual and difficult to discern in the horizontally expansive excavations. As such, subsoil horizons were not differentiated beyond the level of master designation. The break between the Btb and BCb horizon was diffuse and generally coincided with an increase in the size and frequency of redoximorphic features and a subtle decrease in the size and expression of ped structure. Where the base of the BCb horizon was exposed, the $\mathrm{BCb}$ horizon was underlain by a $\mathrm{CBb}$ horizon. The boundary between the $\mathrm{BCb}$ and $\mathrm{CBb}$ horizons was very diffuse (Figure 27) and difficult to discern during field work. This break was identified primarily from the results of particle-size analysis and was defined by the transition from silty clay loam to silt loam textures in Sediment Columns 1 and 2 (Appendix).

The only C horizon identified in this study was exposed in the deepest excavations, below $\sim 513 \mathrm{~cm}$ depth, in the central portion of the Pier 5 excavation, in the E500 Trench, E500 Trench Extension, and in $1 \mathrm{~m}$ x $1 \mathrm{~m}$ archaeological test units N436 E492 and N436 E495. The C horizon was comprised of the northward-dipping alluvial beds identified as SU IV (Figure 21). Thorough sampling and description of the C horizon was precluded by time constraints, limited exposures, and unsafe conditions in the flooded E500 Trench Extension. 


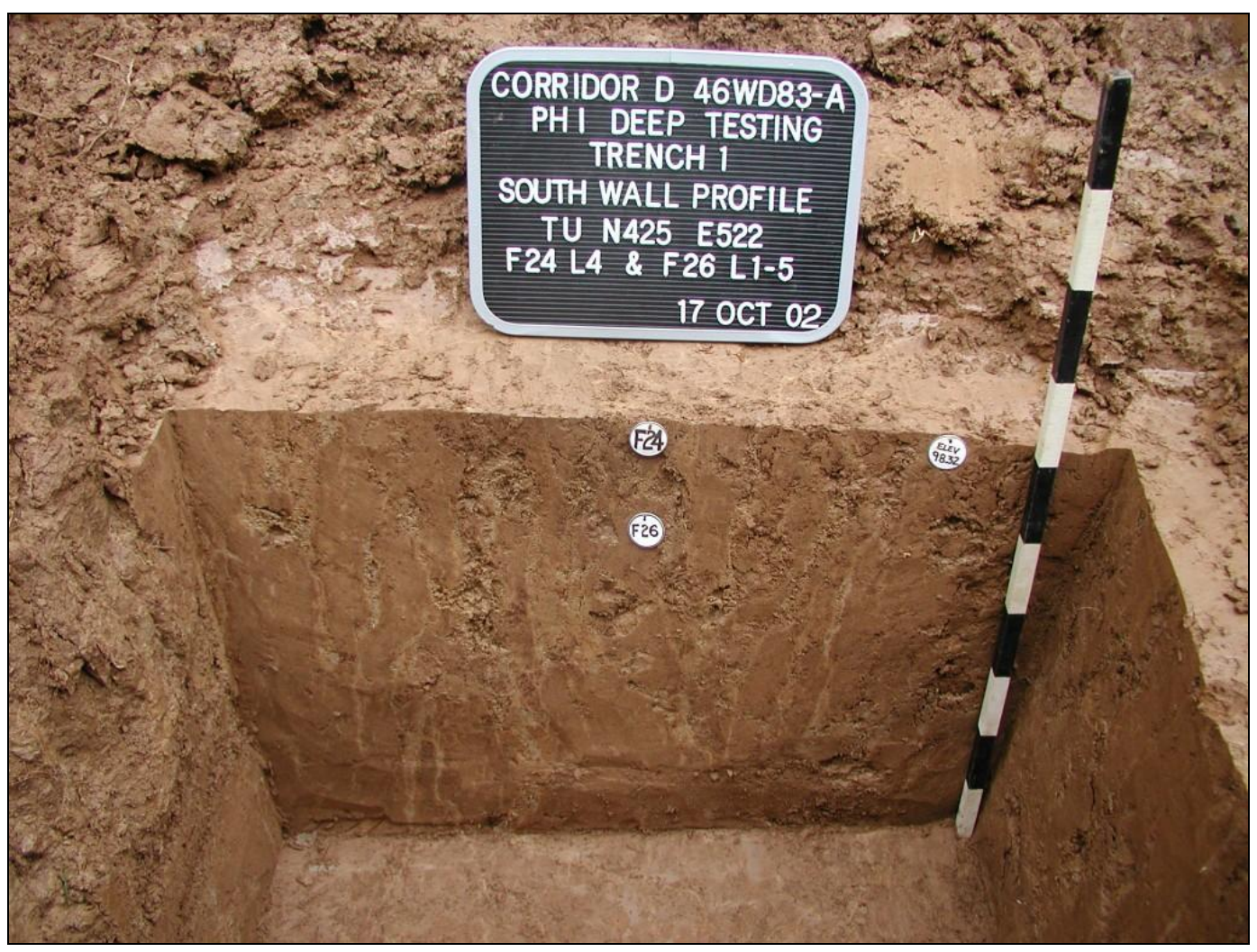

Figure 27: Profile of test unit N425 E522 in Deep Test 1 between roughly 230 and 290 cm depth (179.89 and 179.29 m AMSL) facing south. The BCb to CBb horizon transition occurs near the top of this profile. Note the many coarse redoximorphic features and otherwise homogeneous color of the matrix. Scale bar is marked in $10 \mathrm{~cm}$ divisions.

\section{Cultural Stratigraphy}

Six cultural strata, CS I through CS VI (Table 9), and four occupational components, OC 1, OC 2, OC 3, and OC 4 (Table 10), were identified at West Blennerhassett (Figure 28). A fifth occupational component designation, OC 2A, was assigned to a subsection of OC 2. Stratified archaeological deposits were most abundant in CS II, CS IV, and CS V. CS I correlates with the ^A, Ap, and Apb soil horizons; archaeological material was recovered from CS I, but always from disturbed context. CS III is defined by an absence of archaeological deposits. Archaeological deposits 
Table 9: Cultural strata in Deep Test 1, Deep Test 2, Area 1, and Pier 5.

\begin{tabular}{|c|c|c|c|c|c|c|c|c|}
\hline $\begin{array}{l}\text { Cultural } \\
\text { Stratum }\end{array}$ & $\begin{array}{l}\text { Elevation } \\
\text { Range } \\
\text { (m AMSL) } \\
\text { Deep Test } 1\end{array}$ & $\begin{array}{l}\text { Elevation } \\
\text { Range } \\
\text { (m AMSL) } \\
\text { Deep Test } 2\end{array}$ & $\begin{array}{l}\text { Elevation } \\
\text { Range } \\
\text { (m AMSL) } \\
\text { Pier } 5 \\
\text { South }\end{array}$ & $\begin{array}{l}\text { Elevation } \\
\text { Range } \\
\text { (m AMSL) } \\
\text { Pier } 5 \text { North }\end{array}$ & $\begin{array}{l}\text { Field } \\
\text { Designation } \\
\text { (F\#) }\end{array}$ & $\begin{array}{l}\text { Sedimentary } \\
\text { Unit }\end{array}$ & Soil Horizon & $\begin{array}{l}{ }^{14} \mathrm{C} \text { Ages } \\
\text { radiocarbon yr B.P. }\end{array}$ \\
\hline CSI & $182.19-181.77$ & $182.13-181.67$ & $\begin{array}{l}182.17- \\
181.77 \\
\end{array}$ & $\begin{array}{l}182.13- \\
181.67\end{array}$ & F3, F4, F9, F11 & SU 1 & $\mathrm{Ap}, \wedge \mathrm{A}, \mathrm{Apb}$ & N/A \\
\hline CS II & $181.77-180.99$ & $181.67-180.45$ & $\begin{array}{l}181.77- \\
180.69\end{array}$ & $\begin{array}{l}181.67- \\
180.47\end{array}$ & $\begin{array}{l}\text { F5, F6, F8, F12, } \\
\text { F13, F14, F18, } \\
\text { F19, F25, F27, } \\
\text { F28, F33, F35, } \\
\text { F38, F40 }\end{array}$ & $\begin{array}{l}\text { lower SU 1, } \\
\text { upper SU } 2\end{array}$ & $\mathrm{Bw}, \mathrm{Ab}, \mathrm{Btb}$ & $\begin{array}{l}1375 \pm 30 \text { (ISGS-A0887), } \\
1960 \pm 30 \text { (ISGS-A0893), } \\
2225 \pm 30 \text { (ISGS-A0903), } \\
2595 \pm 30 \text { (ISGS-A0863), } \\
2855 \pm 30 \text { (ISGS-A0888), } \\
2885 \pm 30 \text { (ISGS-A0884), } \\
3000 \pm 30 \text { (ISGS-A0861), } \\
3055 \pm 35 \text { (ISGS-A0862), } \\
3105 \pm 30 \text { (ISGS-A0864), } \\
3120 \pm 30 \text { (ISGS-A0892), } \\
4315 \pm 30 \text { (ISGS-A0894) }\end{array}$ \\
\hline CS III & $180.99-179.69$ & $180.45-178.65$ & $\begin{array}{l}180.69- \\
179.69\end{array}$ & $\begin{array}{l}180.47- \\
178.92\end{array}$ & $\mathrm{~F} 5, \mathrm{~F} 24, \mathrm{~F} 26$ & SU 2, SU 3. & $\mathrm{Btb}, \mathrm{BCb}$ & $\mathrm{N} / \mathrm{A}$ \\
\hline CS IV & $179.69-178.19$ & $\begin{array}{l}\text { 178.65-178.45 } \\
(\mathrm{BOE})+\end{array}$ & $\begin{array}{l}179.69- \\
178.20\end{array}$ & $\begin{array}{l}178.92- \\
177.57\end{array}$ & $\begin{array}{l}\text { F26, F44, F45, } \\
\text { F203, F233, } \\
\text { F256, F257 }\end{array}$ & SU 3 & $\mathrm{CBb}$ & $\begin{array}{l}7010 \pm 40 \text { (ISGS-A0860), } \\
7760 \pm 35 \text { (ISGS-A0899), } \\
7825 \pm 40 \text { (ISGS-A0881), } \\
7845 \pm 25 \text { (ISGS-A0868), } \\
7850 \pm 35 \text { (ISGS-A0904), } \\
7910 \pm 35 \text { (ISGS-A0889), } \\
7940 \pm 30 \text { (ISGS-A0869), } \\
7965 \pm 35 \text { (ISGS-A0882), } \\
7985 \pm 30 \text { (ISGS-A0872), } \\
8005 \pm 35 \text { (ISGS-A0900), } \\
8020 \pm 35 \text { (ISGS-A0873), } \\
8075 \pm 35 \text { (ISGS-A0902) }\end{array}$ \\
\hline CS V & $\begin{array}{l}178.19-177.39 \\
\left(\mathrm{BOE}^{\mathrm{a}}\right)+\end{array}$ & $\mathrm{N} / \mathrm{A}$ & $\begin{array}{l}178.20- \\
177.07\end{array}$ & $\begin{array}{l}177.57- \\
176.42\end{array}$ & $\begin{array}{l}\text { F26, F203, } \\
\text { F204, F246, } \\
\text { F257, F258, } \\
\text { F259 }\end{array}$ & SU 3 & $\mathrm{CBb}$ & $\begin{array}{l}8025 \pm 35 \text { (ISGS-A0879), } \\
8165 \pm 35 \text { (ISGS-A0880), } \\
8215 \pm 35 \text { (ISGS-A0886), } \\
8245 \pm 35 \text { (ISGS-A0885), } \\
8235 \pm 40 \text { (ISGS-A0870), } \\
8265 \pm 35 \text { (ISGS-A0905), } \\
8340 \pm 40 \text { (ISGS-A0906), } \\
8355 \pm 30 \text { (ISGS-A0871), } \\
8360 \pm 50 \text { (ISGS-A0890), } \\
8660 \pm 40 \text { (ISGS-A0883) }\end{array}$ \\
\hline CS VI & N/A & $\mathrm{N} / \mathrm{A}$ & $\begin{array}{l}177.07 \\
\text { (BOE)+ }\end{array}$ & $\begin{array}{l}\text { 176.42- } \\
\text { BOE+ }\end{array}$ & F255, F260 & SU 4 & $\mathrm{C}$ & N/A \\
\hline
\end{tabular}

${ }^{\mathrm{a}} \mathrm{BOE}=$ base of excavation. 
Table 10: Occupational components at West Blennerhassett.

\begin{tabular}{|c|c|c|c|c|c|c|c|}
\hline $\begin{array}{l}\text { Occupational } \\
\text { Component }\end{array}$ & $\begin{array}{l}\text { Excavation } \\
\text { Area }\end{array}$ & $\begin{array}{l}\text { Horizontal } \\
\text { Extent }\end{array}$ & $\begin{array}{l}\text { Elevation } \\
\text { Range } \\
\text { (m AMSL) }\end{array}$ & $\begin{array}{l}\text { Field } \\
\text { Designation }\end{array}$ & $\begin{array}{l}\text { Diagnostic } \\
\text { Artifacts }\end{array}$ & $\begin{array}{l}\text { Cultural } \\
\text { Features } \\
\text { (Feature \#) }\end{array}$ & $\begin{array}{l}{ }^{14} \mathrm{C} \text { Ages } \\
\text { radiocarbon yr B.P. }\end{array}$ \\
\hline OC 1 & $\begin{array}{l}\text { Deep } \\
\text { Test } 1\end{array}$ & $\begin{array}{l}\text { N424.5-N426.5 } \\
\text { E522-E525 }\end{array}$ & $178.89-178.59$ & F26 & $\begin{array}{l}1 \text { Kirk Serrated } \\
\mathrm{pp} / \mathrm{k}\end{array}$ & $\begin{array}{l}31,32,34,36, \\
41\end{array}$ & $\begin{array}{l}7825 \pm 40 \text { (ISGS-A0881) } \\
7965 \pm 35 \text { (ISGS-A0882) }\end{array}$ \\
\hline OC 2 & Pier 5 & $\begin{array}{l}\text { Western Pier 5 = } \\
\text { N434-N441 } \\
\text { Eastern Pier } 5= \\
\text { N428-N433 } \\
\text { E486-E514 }\end{array}$ & $178.84-178.59$ & F26, F226, F233 & $\begin{array}{l}3 \text { Kirk Serrated } \\
\mathrm{pp} / \mathrm{ks} \\
2 \text { probable Kirk } \\
\text { Serrated pp/k } \\
\text { fragments }\end{array}$ & $\begin{array}{l}\text { 156, 158, 166, } \\
\text { 171, 172, 177, } \\
\text { 178, 182, 183, } \\
\text { 195, 197, 198, } \\
209,210,211, \\
212,214,215, \\
217,219,221, \\
222,223,224, \\
225,226,227, \\
230,231,235, \\
237,239,240, \\
241,242,243, \\
244,247,251, \\
254,261\end{array}$ & $\begin{array}{l}7760 \pm 35 \text { (ISGS-A0899), } \\
7845 \pm 25 \text { (ISGS-A0868), } \\
7910 \pm 35 \text { (ISGS-A0889), } \\
7940 \pm 30 \text { (ISGS-A0869), } \\
7985 \pm 30 \text { (ISGS-A0872), } \\
8005 \pm 35 \text { (ISGS-A0900), } \\
8020 \pm 35 \text { (ISGS-A0873), } \\
8075 \pm 35 \text { (ISGS-A0902) }\end{array}$ \\
\hline OC $2 A$ & Pier 5 & $\begin{array}{l}\text { N428-N441 } \\
\text { E500-E514 }\end{array}$ & $178.75-178.59$ & F26, F226, F233 & $\begin{array}{l}3 \text { Kirk Serrated } \\
\mathrm{pp} / \mathrm{ks} \\
2 \text { probable Kirk } \\
\text { Serrated pp/k } \\
\text { fragments }\end{array}$ & $\begin{array}{l}172,182,183, \\
195,210,211, \\
214,215,217, \\
225,226,227, \\
230,231,235, \\
239,240,241, \\
242,243,244, \\
254,261\end{array}$ & $\begin{array}{l}7760 \pm 35 \text { (ISGS-A0899), } \\
7845 \pm 25 \text { (ISGS-A0868), } \\
7910 \pm 35 \text { (ISGS-A0889), } \\
7940 \pm 30 \text { (ISGS-A0869), } \\
8005 \pm 35 \text { (ISGS-A0900), } \\
8020 \pm 35 \text { (ISGS-A0873), } \\
8075 \pm 35 \text { (ISGS-A0902) }\end{array}$ \\
\hline OC 3 & $\begin{array}{l}\text { Deep } \\
\text { Test } 1\end{array}$ & $\begin{array}{l}\text { N425-N426.5 } \\
\text { E521-E524.5 }\end{array}$ & $177.89-177.39$ & $\mathrm{~F} 44, \mathrm{~F} 45$ & 2 LeCroy pp/ks & $\begin{array}{l}46,47,48,49, \\
50\end{array}$ & $\begin{array}{l}8235 \pm 40 \text { (ISGS-A0870), } \\
8245 \pm 35 \text { (ISGS-A0885) }\end{array}$ \\
\hline OC 4 & Pier 5 & $\begin{array}{l}\text { N436-N442 } \\
\text { E491-E497 }\end{array}$ & $\begin{array}{l}177.32-176.97 \\
\text { (top) } \\
177.17-176.82 \\
\text { (bottom) }\end{array}$ & F258, F275 & $\begin{array}{l}5 \text { LeCroy pp/ks } \\
1 \text { LeCroy pp/k in } \\
\text { three x-mending } \\
\text { fragments } \\
1 \text { Kirk Corner } \\
\text { Notched pp/k }\end{array}$ & $273,276,288$ & $\begin{array}{l}8215 \pm 35 \text { (ISGS-A0886), } \\
8355 \pm 30 \text { (ISGS-A0871), } \\
8660 \pm 40 \text { (ISGS-A0883) }\end{array}$ \\
\hline
\end{tabular}




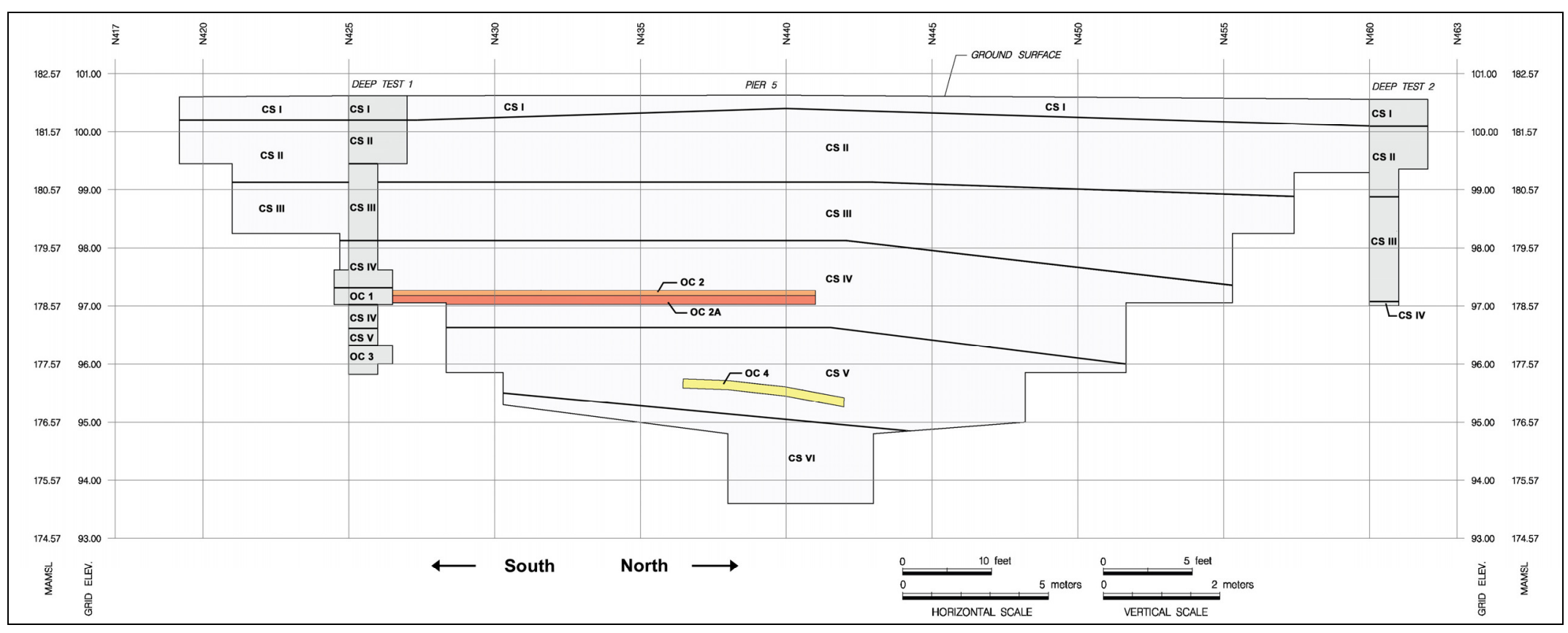

Figure 28: Generalized profile of Deep Test 1, Deep Test 2, and Pier 5 facing downriver (west) and showing Cultural Strata I through VI and Occupational Components 1 through 4 with vertical exaggeration of 2. 
identified in CS VI were limited to three lithic artifacts and a small scattering of charcoal. Two of the cultural strata, CS IV and CS V, each housed two rather distinct occupational components; OC 1 and 2/2A were within CS IV, OC 3 and 4 were within CS V.

Both the cultural strata and occupational components are described in terms of their anthropogenic attributes, morphological characteristics, stratigraphic positioning, and radiocarbon chronology. Occupational components were identified primarily by the distribution of artifacts and features in close vertical and horizontal proximity in matrixes that exhibited laterally extensive, relatively well-preserved anthropogenic modifications indicated by high volumes of charcoal and oxidized sediment. In addition, occupational component designations were assigned only to discrete feature and artifact clusters that contained diagnostic projectile points/knives (pp/k) that can be linked with distinct cultural traditions.

As with the sedimentology and pedology, the cultural stratigraphy was developed primarily from data recovered during Phase I deep testing (2002) and Phase III data recovery (2003) excavations. Accordingly, the cultural strata and occupational component descriptions and correlations within are focused on results from the Deep Test 1, Deep Test 2, Area 1, and Pier 5 excavations. A series of photographs showing the Pier

5 excavation as it appeared at intervals that correspond with cultural strata are provided in Figures 29-32.

\section{Cultural Stratum I (CS I)}

CS I consisted exclusively of cultural deposits that occurred in the $\wedge$ A and Ap horizons. The vertical extent of CS I was defined by the depth of the plow zone, which generally occurred at 40-50 cm depth, although the unit thinned towards central Area 1 


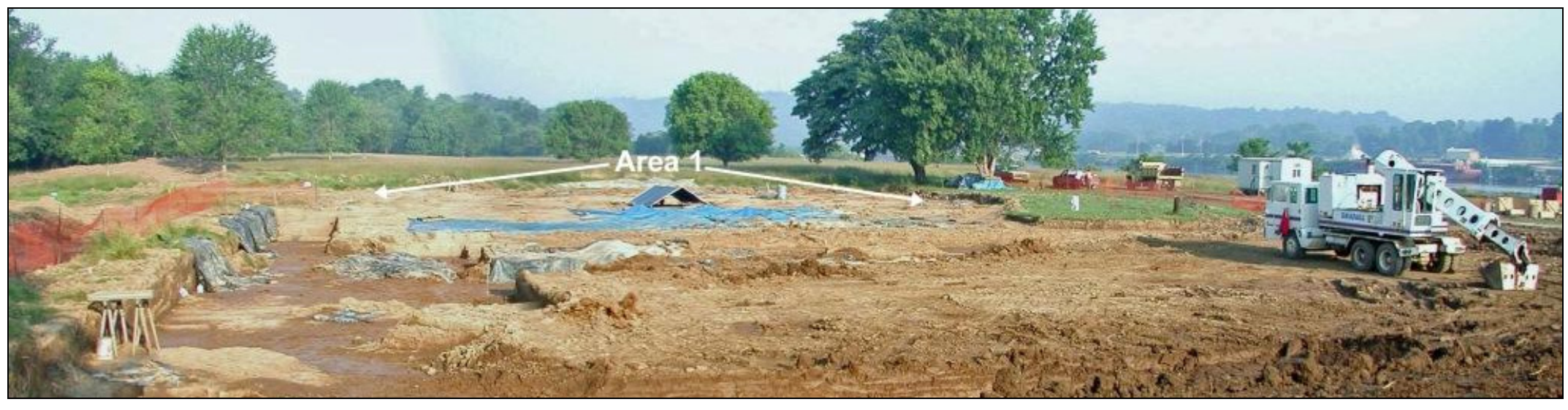

Figure 29: View of Area 1 (background) and Pier 5 excavated to near the top of CS II, facing slightly right of downriver (westnorthwest). Photo taken 24 June 2003.

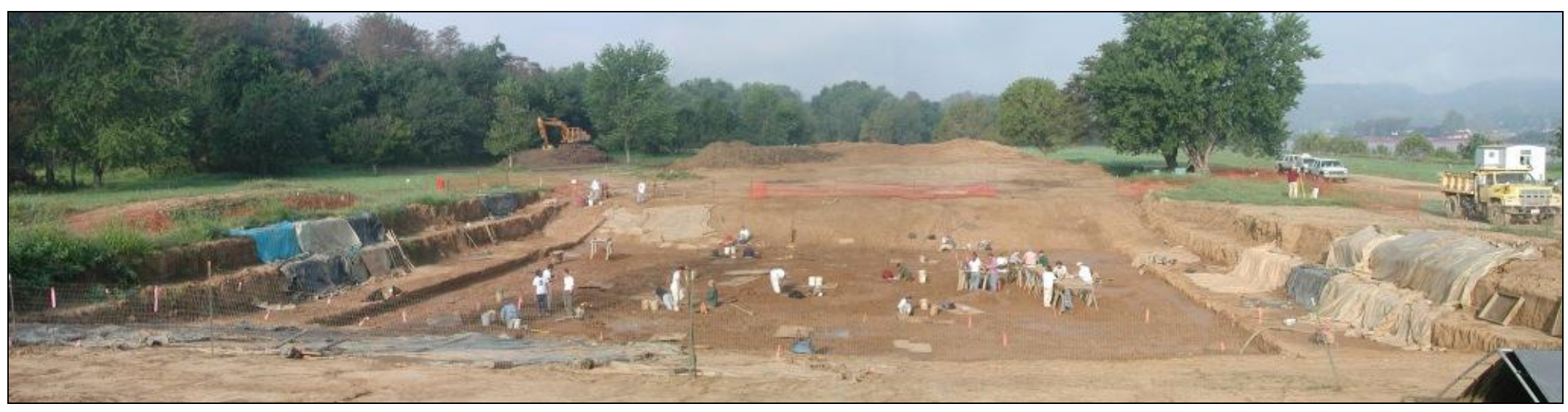

Figure 30: View of Pier 5 excavated to near the top of CS IV, facing downriver (west) on 7 September 2003. 


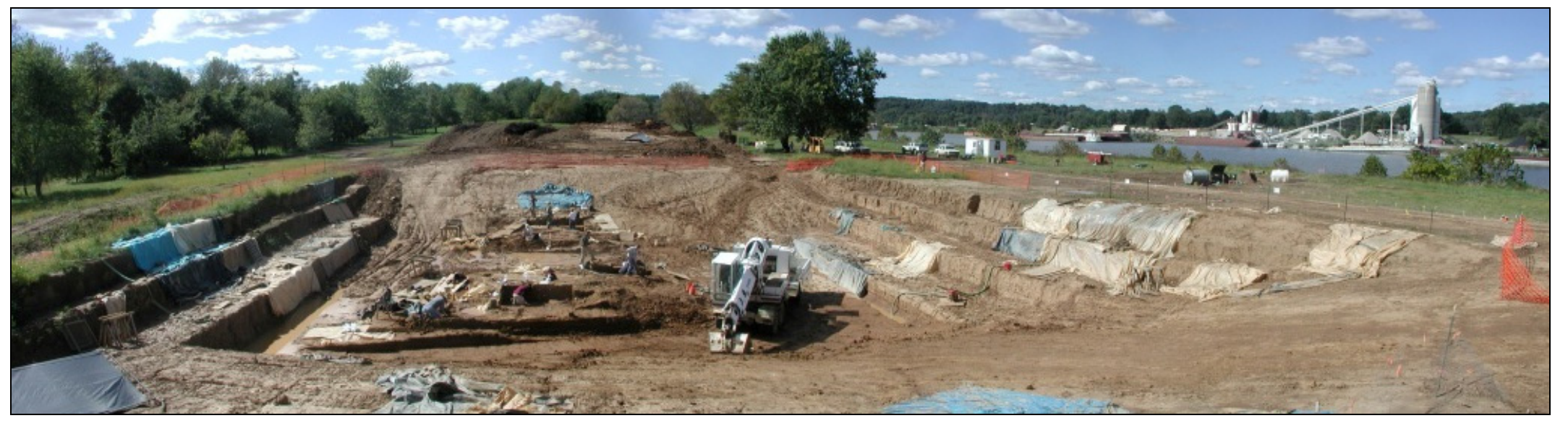

Figure 31: View of Pier 5 excavated mid-way through CS IV, at the levels of OC 2 and OC 2A, facing slightly right of downriver (west-northwest) on 2 October 2003.

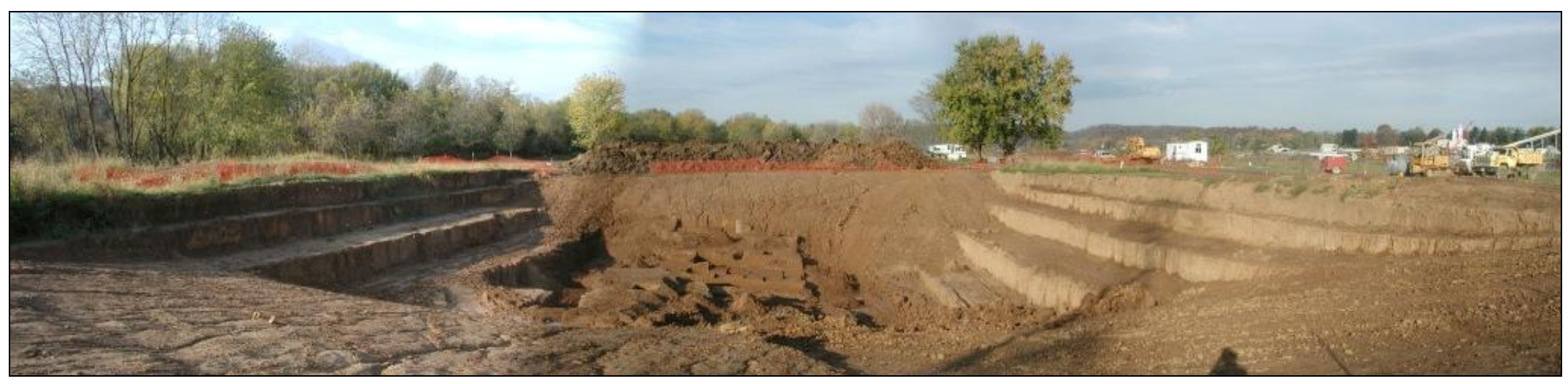

Figure 32: View of Pier 5 excavated to CS V, facing downriver (west) on 31 October 2003. Photo shows Pier 5 upon completion of excavations, immediately prior to backfilling. 
and west-central Pier 5. Historic and prehistoric period artifacts were recovered from CS I, suggesting that mechanical disturbance extended into prehistoric sediments. No samples were submitted for radiocarbon dating from CS I. However, age determinations of $2225 \pm 30$ B.P. (ISGS-A0903) from test unit N443 E456, $1960 \pm 30$ B.P. (ISGSA0893) from Feature 117, and $2885 \pm 30$ B.P. (ISGS-A0884) from Feature 17, the stratigraphically-highest ${ }^{14} \mathrm{C}$ assays from undisturbed strata, indicate the maximum age of deposits that were truncated by mechanical disturbance.

\section{Cultural Stratum II (CS II)}

The top of CS II was marked, across the site, by the base of the plow zone. CS II ranged in thickness from $\sim 78 \mathrm{~cm}$, in Deep Test 1, to $122 \mathrm{~cm}$, in Deep Test 2 (Figure 28). CS II housed closely-spaced, stratified archaeological deposits that span from the Late Archaic through early Late Woodland cultural periods. Various Bw, Ab, and Btb soil horizons have formed on the sediments that housed CS II. Soil formation on these sediments has obliterated primary sedimentary structures and has obscured the stratigraphic relationships between successive archaeological deposits. Due to the lack of clear stratigraphic indicators, such as sedimentary bedding, as well as a paucity of temporally diagnostic artifacts, cultural deposits from CS II are only loosely ascribable to broadly defined temporal/cultural spans.

The buried A (Ab) soil horizon identified in Area 1 and western Pier 5 served as the most distinct stratigraphic marker in CS II (Figure 26). The dark brown (10YR 3/3) color of this horizon, coupled with a relatively high concentration of cultural features and lithic artifacts in a matrix characterized by inclusions of charcoal, carbonized nutshell, and oxidized sediments, suggests that the Ab horizon was heavily influenced by human 
occupants. Three radiocarbon assays associated with the Ab horizon indicate an Early Woodland through initial Middle Woodland cultural affinity for the horizon. Two radiocarbon dates associated with features in the Ab horizon and one radiocarbon date associated with a $5 \mathrm{~cm}$ excavation level in the Ab horizon are, respectively: $2885 \pm 30$ B.P. (ISGS-A0884), $1960 \pm 30$ B.P. (ISGS-A0893), and $2225 \pm 30$ B.P. (ISGS-A0903). One Late Woodland period assay, $1375 \pm 30$ B.P. (ISGS-A0887), is also associated with the Ab horizon. However, ISGS-A0887 was determined on a specimen of carbonized nut shell recovered from Feature 64, a fire feature with a deep bowl-shaped cross-section profile (Figure 33) that may have been intrusive into the Ab horizon from an overlying stratum.

Seven other ${ }^{14} \mathrm{C}$ ages associated with cultural deposits in CS II, below the Ab horizon, further support a Late Archaic through Early Woodland ascription for CS II. Samples from Features 101, 134, 174, 163, 129, and 52 provided ${ }^{14} \mathrm{C}$ ages of $4315 \pm 30$ B.P. (ISGS-A0894), $3120 \pm 30$ B.P. (ISGS-A0892), $3105 \pm 30$ B.P. (ISGS-A0864), 3055 \pm 35 B.P. (ISGS-A0862), $3000 \pm 30$ B.P. (ISGS-A0861), and $2595 \pm 30$ B.P. (ISGSA0863), respectively.

\section{Cultural Stratum III (CS III)}

CS III ranged in thickness from $\sim 100 \mathrm{~cm}$, in southern Pier 5, to $180 \mathrm{~cm}$, in Deep Test 1 (Figure 28). CS III was sampled through combined manual and mechanical excavations in Deep Test 1 and Deep Test 2 and through mechanical excavation at Pier 5. CS III is defined by an apparent total absence of cultural deposits.

No samples from CS III were submitted for radiocarbon dating. However, radiocarbon age ascriptions associated with adjacent cultural strata indicate that the 


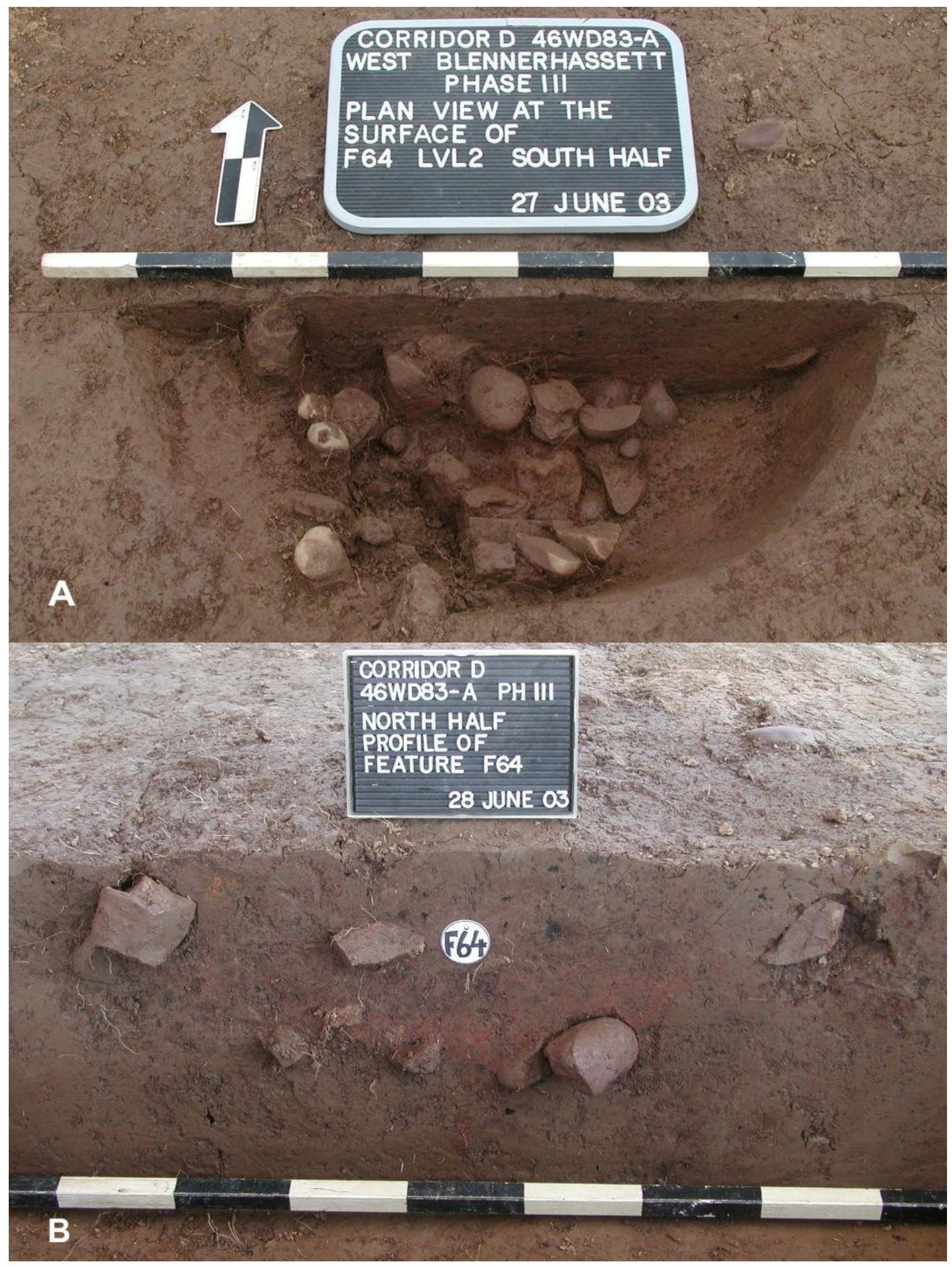

Figure 33: Feature 64 shown partially excavated in plan view (A) and in cross-section profile (B). Scale bars and north arrow are marked in $10 \mathrm{~cm}$ divisions. 
CS III occupational hiatus at West Blennerhassett occurred between the latter part of the Middle Archaic and the early part of the Late Archaic cultural periods. CS III is bracketed by radiocarbon dates of $7010 \pm 40$ B.P. (ISGS-A0860) near the top of the underlying CS IV and $4315 \pm 30$ B.P. (ISGS-A0894) near the base of the overlying CS II.

\section{Cultural Stratum IV (CS IV)}

CS IV ranged in thickness from $\sim 135 \mathrm{~cm}$, in Deep Test 2 to $150 \mathrm{~cm}$, in Deep Test 1 (Figure 28). CS IV is defined by archaeological deposits that span from the terminal Early Archaic through initial Middle Archaic cultural periods based on temporally diagnostic artifacts and radiocarbon dates that range from $8075 \pm 35$ B.P. (ISGS-A0902) through $7010 \pm 40$ B.P. (ISGS-A0860). These archaeological deposits were relatively closely spaced, in both vertical and horizontal dimensions, in the upper portions of CS IV and became more sparsely distributed with depth.

As with CS II, primary sedimentary structures and indicators of distinct occupational surfaces in CS IV have largely been obliterated, presumably through pedoturbation. Because of this obliteration, discrete archaeological surfaces were, for the most part, indiscernible. However, two of the four distinct occupational components, OC 1 and OC 2, were identified near the base of CS IV in Deep Test 1 and Pier 5. These occupational components were identified primarily on the basis of clustering between features and artifacts in matrixes laden with charcoal and oxidized sediment. The distribution of archaeological test units in OC 1 and OC 2 , as well as all other test units in CS IV, is shown in Figure 34. The distribution of cultural features in OC 1 and OC 2 is shown in Figure 35. 


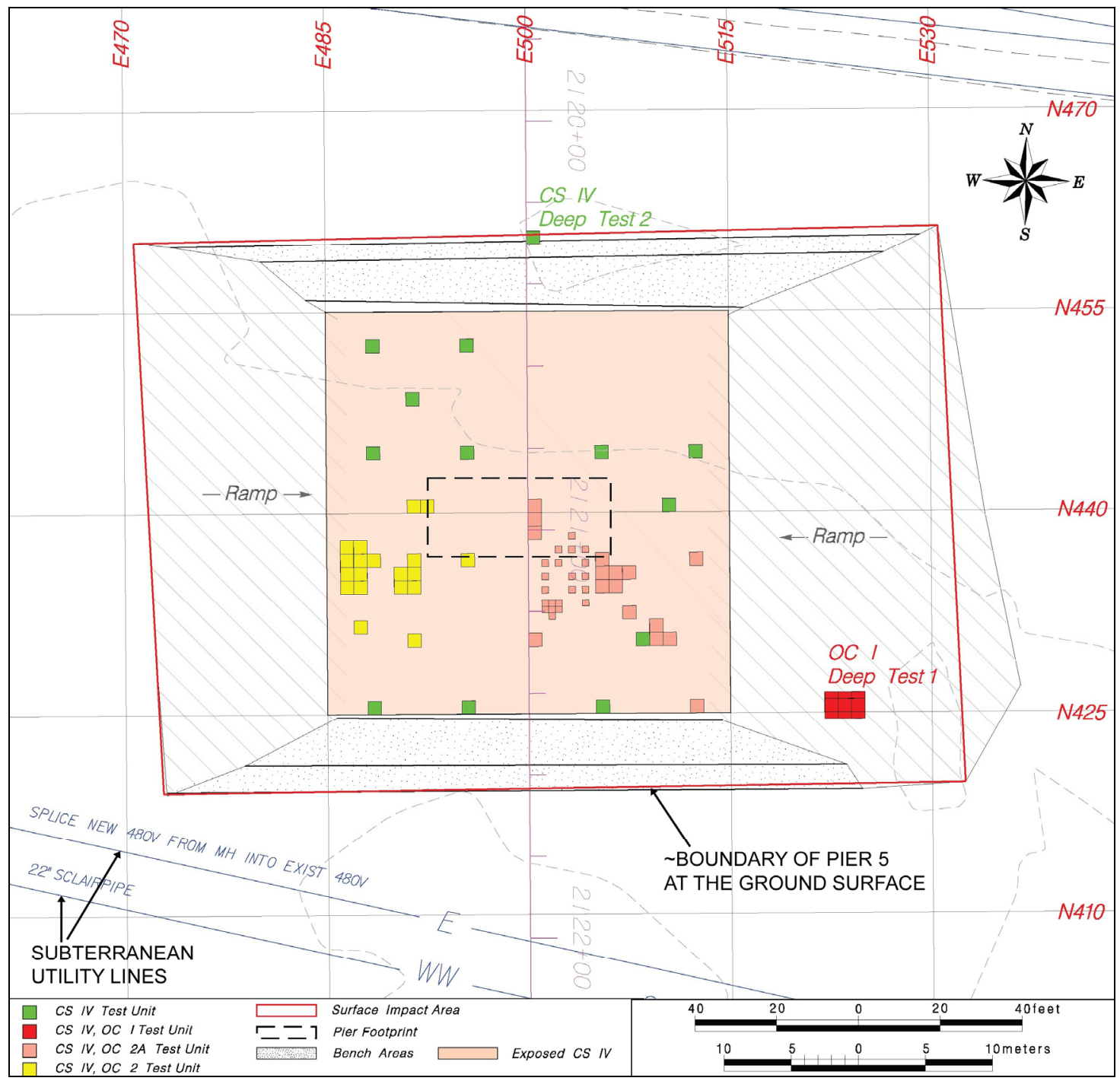

Figure 34: Map of Deep Test 1, Deep Test 2, and the Pier 5 excavation showing the distribution of archaeological test units in CS IV. Note that the test units are color-coded to show the extent of OC 1 and OC 2/2A. Adapted from Robinson et al. 2008. 


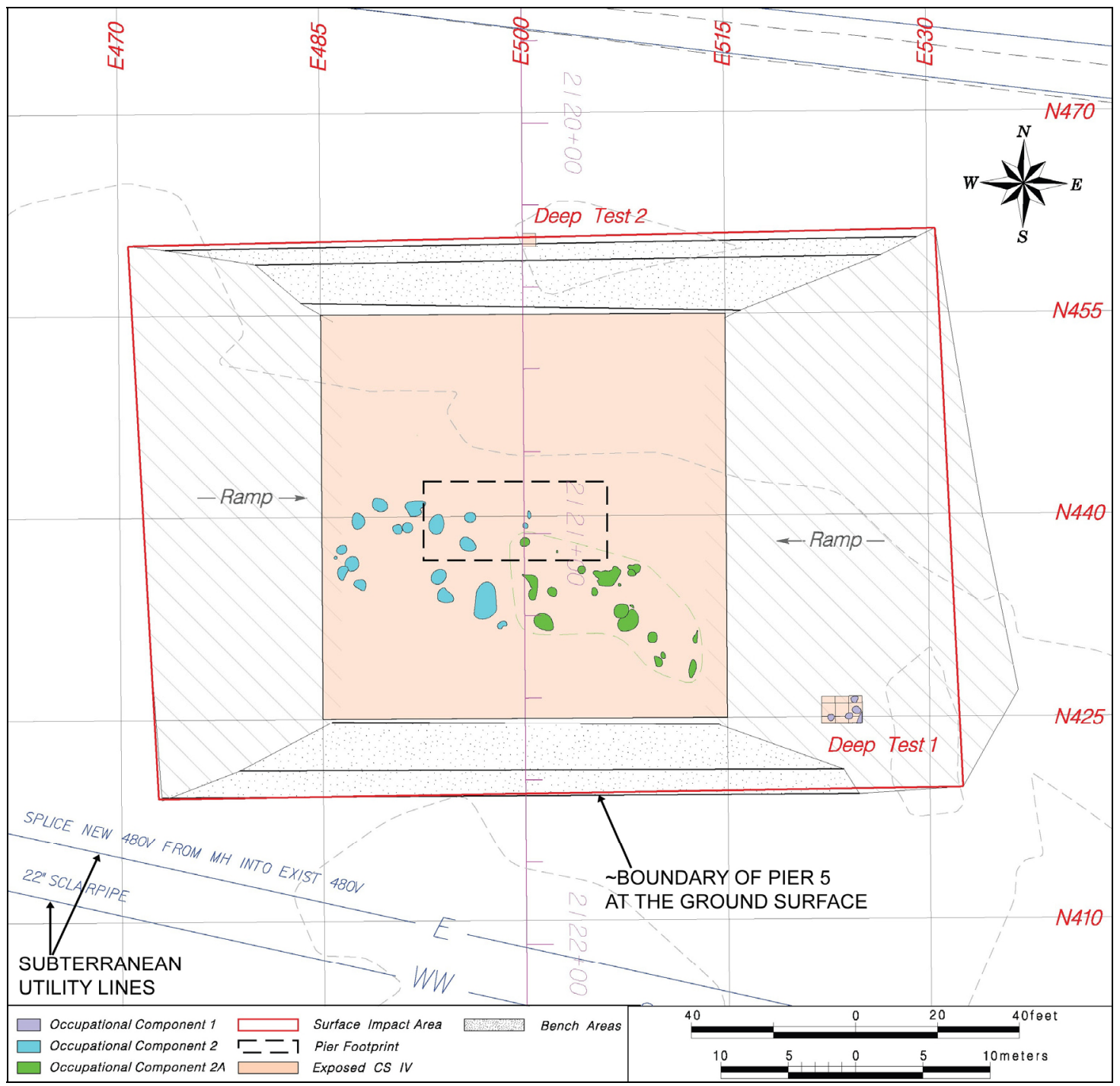

Figure 35: Map of Deep Test 1 and the Pier 5 excavation showing the distribution of cultural features in OC 1 and OC 2/2A. Adapted from Robinson et al. 2008. 


\section{Occupational Components 1 and 2 (OC 1 and OC 2)}

OC 1 was closely related to, if not one in the same as, OC 2. Both occupational components occurred at similar depths/elevations, contained similar archaeological assemblages, and date to similar temporal spans. They were assigned separate occupational component designations due to the fact that they were identified in separate excavation areas (Deep Test 1 and Pier 5) during separate phases of archaeological investigations (Phase I deep testing and Phase III data recovery), and thus it is not possible to determine if the components are connected across a $\sim 8.0 \mathrm{~m}$ wide gap of unexcavated sediment.

OC 1 was identified in Deep Test 1 between 330 and 360 cm depth (178.89 and $178.59 \mathrm{~m}$ AMSL) (Figure 28). OC 1 was sampled through the excavation of three $1 \mathrm{~m} \mathrm{x}$ $1 \mathrm{~m}$ test units (N425 E522, N425 E523, and N425 E524) and six $1 \mathrm{~m}$ x 0.5 m test units (N424.5 E522, N424.5 E523, N424.5 E524, N426 E522, N426 E523, and N426 E524)

(Figure 34). OC 1 was characterized by a cluster of five cultural features and multiple lithic artifacts in a matrix that contained an abundance of charcoal flecks. The high volume of charcoal and presence of cultural features, in particular, defined the vertical limits of OC 1 and set it apart from overlying and underlying archaeological deposits. One Kirk Serrated type pp/k recovered from OC 1 was the only temporally diagnostic artifact retrieved from this occupational component.

OC 1 is bracketed by two ${ }^{14} \mathrm{C}$ dates associated with cultural features. $\mathrm{A}^{14} \mathrm{C}$ age of $7825 \pm 40$ B.P. (ISGS-A0881) was determined on a specimen of carbonized nutshell

from Feature 36 (Figure 36). $\quad \mathrm{A}^{14} \mathrm{C}$ age of $7965 \pm 35$ B.P. (ISGS-A0882) was determined for a specimen of carbonized nutshell from Feature 41. 


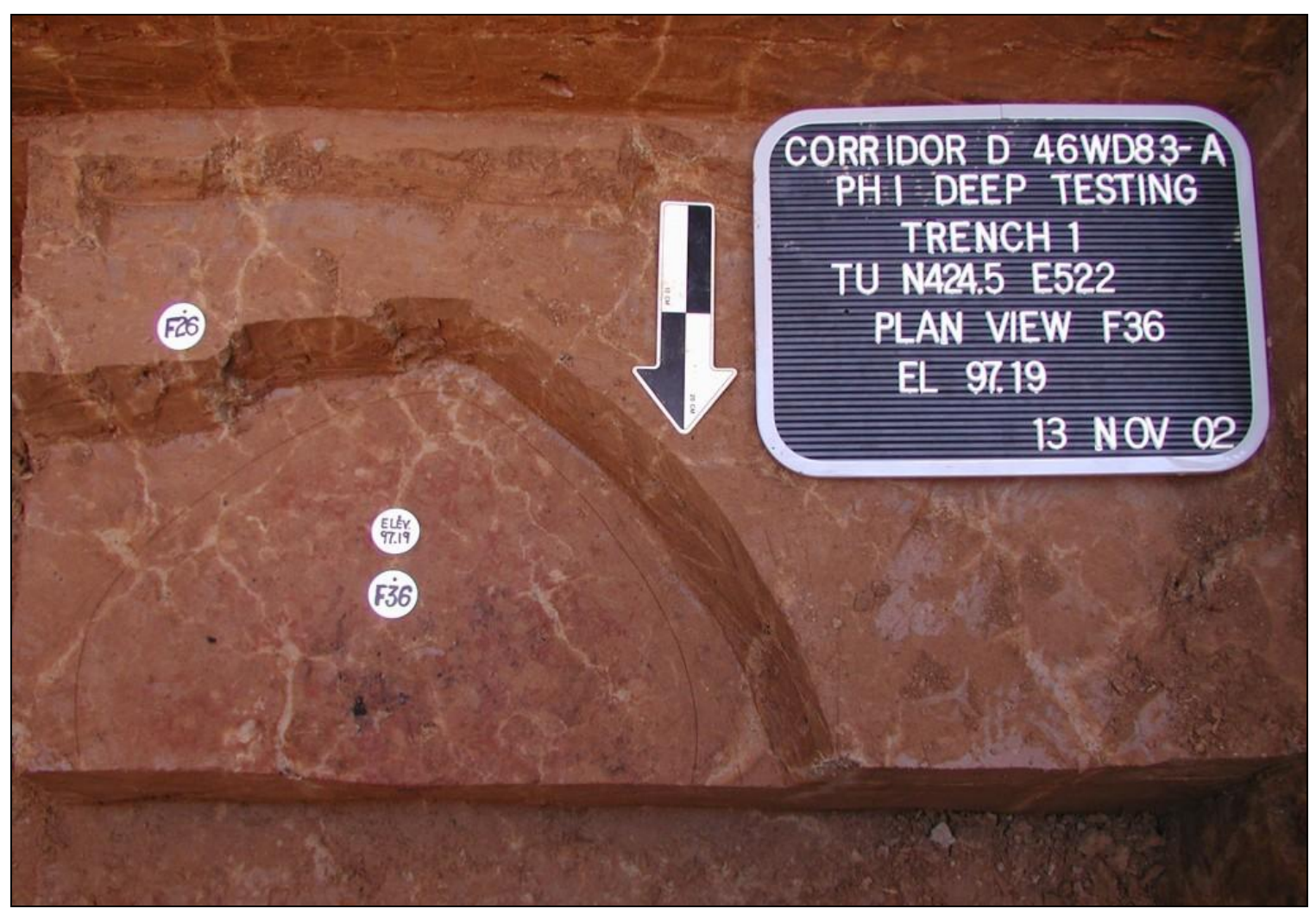

Figure 36: Plan view of the south half of Feature 36, a fire feature in OC 1, Deep Test 1. Note the coarse redoximorphic features that have developed in the feature and the surrounding soil matrix. North arrow is marked in $10 \mathrm{~cm}$ divisions.

OC 2 was identified in Pier 5, between 336 and $368 \mathrm{~cm}$ depth (178.84 and 178.52 m AMSL) (Figure 28) and was defined by a continuous zone of sediment that, in addition to cultural features and artifacts, contained abundant charcoal and localized concentrations of oxidized sediment. OC 2 generally extended from northwest to southeast across Pier 5, roughly between N434 E486 and N441 E486 along the western edge of Pier 5 and between N428 E514 and N433 E514 along the eastern edge of Pier 5 (Figures 34-35).

A distinct archaeological zone, assigned Field Designations F226 and F233 during fieldwork and referred to here as Occupational Component 2A (OC 2A), was identified within the lower portion of OC 2 (Figures 28 and 37). OC 2A extended from 
the central to southeastern portions of Pier 5 and was identified generally between grid N428 and N441 and grid E500 and E514 (Figures 34-35). OC 2A occurred between 345 and $361 \mathrm{~cm}$ depth (178.75 and $178.59 \mathrm{~m}$ AMSL), though it was documented as occurring as shallow as $337 \mathrm{~cm}$ depth (178.83 $\mathrm{m}$ AMSL) and as deep as $367 \mathrm{~cm}$ depth (178.53 m AMSL) in localized areas. OC 2A was characterized by a sediment matrix that contained a particularly high volume of charcoal and oxidized sediment, as well as cultural features and lithic artifacts. Three Kirk Serrated type pp/k and two probable Kirk Serrated $\mathrm{pp} / \mathrm{k}$ fragments recovered from OC $2 \mathrm{~A}$ provide a firm cultural affiliation for this component as well as for all of OC 2 .

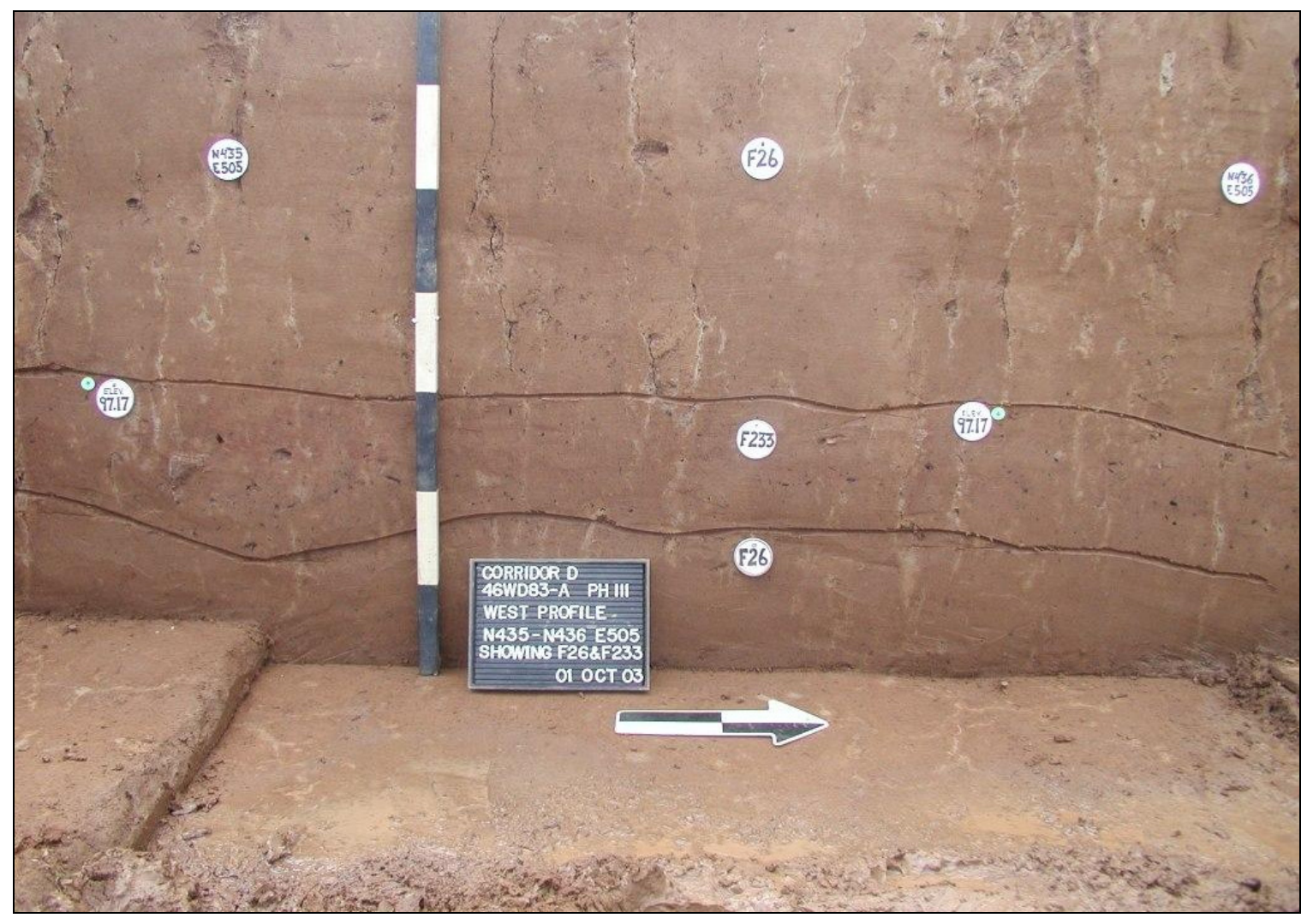

Figure 37: Profile of the west wall of 1 x $1 \mathrm{~m}$ unit N435 E505 showing OC 2A. Scribes mark the top and bottom boundaries of OC 2A. Scale bar and north arrow are marked in $10 \mathrm{~cm}$ divisions. 
Radiocarbon dates obtained from carbonized floral remains from cultural features in OC 2 are vertically confined to the deepest portion of OC 2, between $\sim 348$ an $360 \mathrm{~cm}$ depth (178.72 and 178.6 m AMSL). Several of the ${ }^{14} \mathrm{C}$ dates were obtained from samples directly associated with OC 2A features, while others are from OC 2 elevation ranges that correlate with OC $2 \mathrm{~A}$ elevations. Though somewhat vertically confined within the OC 2 elevation range, these age determinations provide temporal reference for a laterally extensive portion of the OC 2 deposits between roughly grid E487 and E508. Age determinations for OC 2, including OC 2A, range between $7760 \pm 35$ B.P. (ISGS-A0899) for a specimen of carbonized nutshell from Feature 231 and $8075 \pm 35$ B.P. (ISGSA0902) for an aggregate sample of very small fragments of unidentified wood charcoal from Feature 230.

Of the floral specimens from OC 2 cultural features that were submitted for radiocarbon dating, those associated with the highest and lowest features, Feature 209 ( 348 cm depth [178.72 m AMSL]) and Feature 239 ( 360 cm depth [178.60 m AMSL]), provided age determinations that fall within the range provided by Features 230 and 231 . A ${ }^{14} \mathrm{C}$ date of $7985 \pm 30$ B.P. (ISGS-A0872) was determined for a specimen of carbonized nutshell from Feature 209, a ${ }^{14} \mathrm{C}$ date of $8005 \pm 35$ B.P. (ISGS-A0900) was determined for a specimen of carbonized nutshell from Feature 239.

\section{Cultural Stratum V (CS V)}

CS V was $\sim 115 \mathrm{~cm}$ thick in the Pier 5 excavation. Approximately $80 \mathrm{~cm}$ of CS V was sampled in Deep Test 1, but excavation of Deep Test 1 was halted prior to encountering the base of CS V. Excavation of Deep Test 2 was halted in CS IV, prior to encountering CS V. The base of CS V was only encountered near the bottom of two $1 \mathrm{~m}$ 
x 1 m test units, N436 E492 and N436 E495, and in the E500 Trench in the central portion of Pier 5. Where observed, the base of CS V conformably overlaid the northward-dipping alluvial beds that characterize SU 4 and the C horizon. The break between CS V and the underlying CS VI was rather abrupt; it was marked by the highest laterally continuous unmodified alluvial bed.

CS V was distinguished by the presence of relatively sparsely distributed archaeological deposits that date to the late Early Archaic period based on radiocarbon dates that span from $8660 \pm 40$ B.P. (ISGS-A0883) to $8025 \pm 35$ B.P. (ISGS-A0879). These archaeological deposits consisted largely of cultural features and artifacts occurring at varying elevations and horizontal proveniences throughout CS V, some of which presumably occurred along conterminous occupation surfaces.

The SU 3 sediments that housed CS V were underlain by a package of sediments that clearly dipped northward at five percent, i.e., those in SU 4. Correlation between radiocarbon dates from several cultural features in CS V indicates that the Early Archaic denizens of the site were occupying a similar sloping landform. The deepest cultural feature at the site, Feature 268, occurred along the northern portion, near the base of Pier 5 at $\sim 549 \mathrm{~cm}$ depth (176.56 m AMSL). A radiocarbon age of $8360 \pm 50$ B.P. (ISGSA0890), determined for one carbonized grape (Vitus sp.) seed, from Feature 268 falls within the 2-sigma radiocarbon age range of 8740-8145 B.P. established for OC 4 (see below), an occupational component that was centered $\sim 9 \mathrm{~m}$ south of, and $67 \mathrm{~cm}$ above Feature 268. The radiocarbon date associated with Feature 268 also compares favorably with age determinations of: $8265 \pm 35$ B.P. (ISGS-A0905) associated with Feature 282 located 10 m south of, and $67 \mathrm{~cm}$ above Feature 268; and $8340 \pm 40$ B.P. (ISGS-A0906) 
associated with Feature 272 located $\sim 10 \mathrm{~m}$ south of and $99 \mathrm{~cm}$ above Feature 268 .

Correlation of radiocarbon dates from Feature 268 and Features 272 and 282 further supports the notion that early Holocene occupants at West Blennerhassett inhabited a northward-dipping paleolandform.

Two of the four defined occupational components, Occupational Component 3 (OC 3) and Occupational Component 4 (OC 4), occurred in CS V. Both occupational components consisted of discrete archaeological remains from what appear to have been single episodes of occupation. Both components are associated with LeCroy Bifurcated Stem (LeCroy) pp/ks. The distribution of archaeological test units in OC 3 and OC 4, as well as all of CS V, is shown in Figure 38.

\section{Occupational Component 3 (OC 3)}

OC 3 was identified in Deep Test 1 between 430 and $480 \mathrm{~cm}$ depth (177.89 and 177.39 m AMSL) (Figure 28). The horizontal boundaries of OC 3 were defined by the limits of excavation of $1 \mathrm{~m}$ x $1 \mathrm{~m}$ test units N425 E521, N425 E522, and N425 E523, and 1 m x 0.5 m test units N425 E524, N426 E522 and N426 E523 (Figure 38). OC 3 was characterized by a cluster of five cultural features and numerous lithic artifacts. Cultural deposits ascribed to OC 3 were contained in two distinct sedimentary contexts: (1) a probable splay deposit, Field Designation F44, identified between 430 and $450 \mathrm{~cm}$ depth (177.89 and $177.69 \mathrm{~m}$ AMSL) and (2) the intact remains of what appears to be a discrete occupation surface, Field Designation F45. Several lithic artifacts were recovered from F44; the interpreted sedimentary context of F44 suggests that the artifacts recovered from this splay deposit were in secondary context, after having been displaced from their primary depositional context in F45. All intact cultural features were contained within 
F45. Two LeCroy pp/ks were recovered from OC 3: one LeCroy $\mathrm{pp} / \mathrm{k}$ was recovered from the F44 splay deposit and a second LeCroy pp/k was recovered from the intact F45 occupation surface.

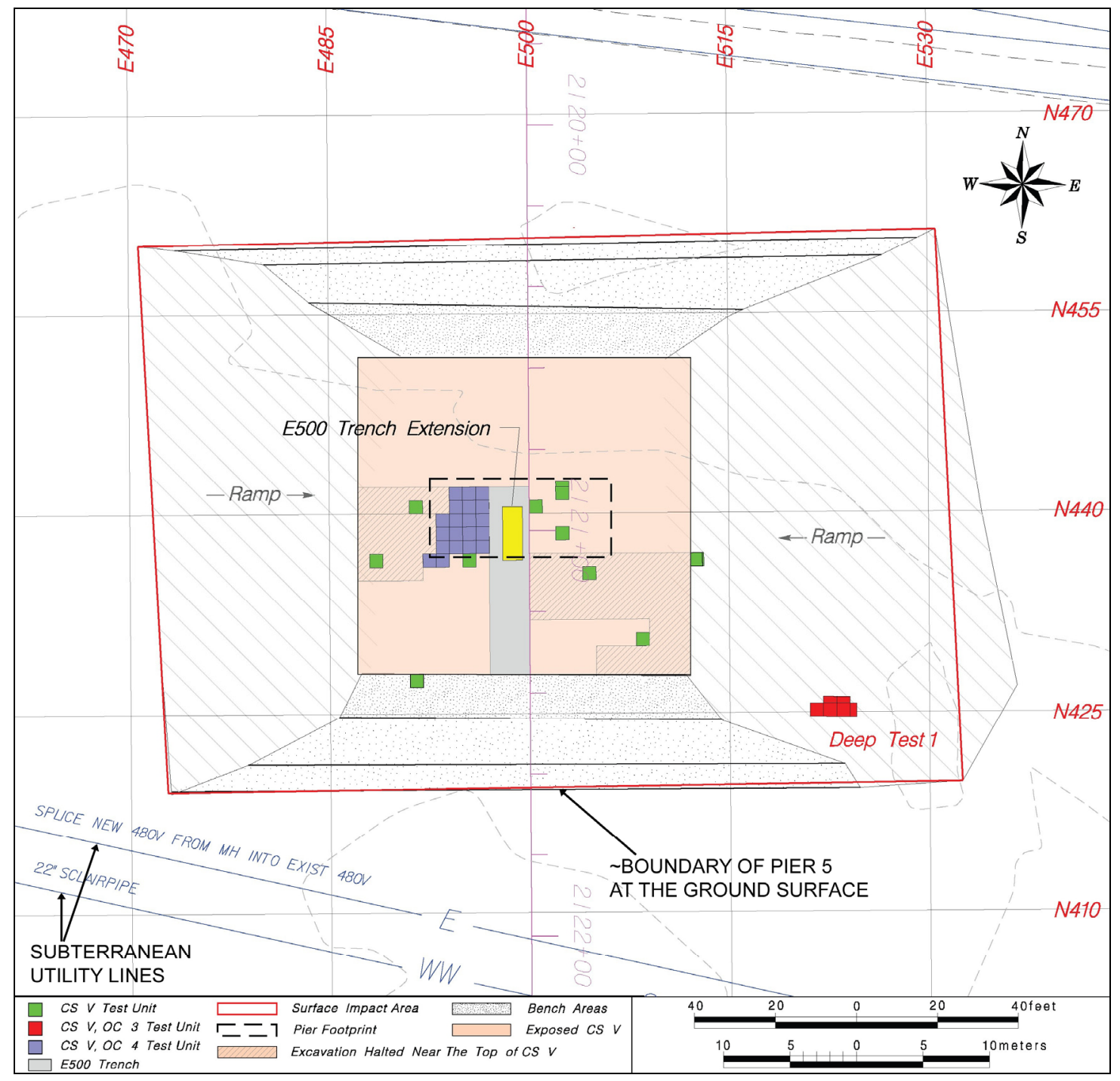

Figure 38: Map of Deep Test 1 and the Pier 5 excavation showing the distribution of archaeological test units in CS V. Note that the test units are color-coded to show the extent of OC 3 and OC 4. Also note the E500 Trench and E500 Trench Extension. Adapted from Robinson et al. 2008. 
Two ${ }^{14} \mathrm{C}$ dates were determined for carbonized floral specimens from cultural features associated with OC 3 . An age of $8245 \pm 35$ B.P. (ISGS-A0885) was determined for one piece of carbonized nutshell from Feature 48 and an age of $8235 \pm 40$ B.P. (ISGS-A0870) was determined for five pieces of unidentified hardwood wood charcoal from Feature 50. The surfaces of these features were identified at 453 and $452 \mathrm{~cm}$ depth (177.66 and $177.67 \mathrm{~m}$ AMSL), respectively.

\section{Occupational Component 4 (OC 4)}

OC 4 was a discrete archaeological phenomenon identified in Pier 5 between 488 and $538 \mathrm{~cm}$ depth (177.32 and $176.82 \mathrm{~m}$ AMSL) (Figure 28) and between grid transects N436 and N442 and E491 and E497 (Figure 38). OC 4 was characterized by a concentration of cultural features and lithic artifacts in a matrix that contained a noticeably high volume of charcoal and a laterally continuous area of oxidized sediment (Figures 39-41). OC 4 clearly dipped towards the north at $\sim$ five percent, reflecting occupation along a sloped paleolandform surface (Figure 41).

OC 4 was initially identified during mechanical excavation of the E500 Trench and was subsequently sampled through a block of 20 contiguous, manually excavated 1 m x $1 \mathrm{~m}$ test units (Figures 38 and 42). Three cultural features, Features 273, 276, and 288, were identified within, and partially define the extent of OC 4. Several LeCroy pp/k and fragments of LeCroy pp/k were recovered from OC 4 in addition to one Kirk Corner Notched type pp/k.

Three ${ }^{14} \mathrm{C}$ ages were determined for carbonized floral specimens from cultural features associated with OC 4 . An age of $8660 \pm 40$ B.P. (ISGS-A0883) was determined for one specimen of wood charcoal from Feature 288 (Figure 39), an age of $8355 \pm 30$ 
B.P. (ISGS-A0871) was determined for one specimen of carbonized nutshell from

Feature 276 (Figure 40), and an age of $8215 \pm 35$ B.P. (ISGS-A0886) was determined for 3 pieces of wood charcoal from Feature 273 (Figure 40).

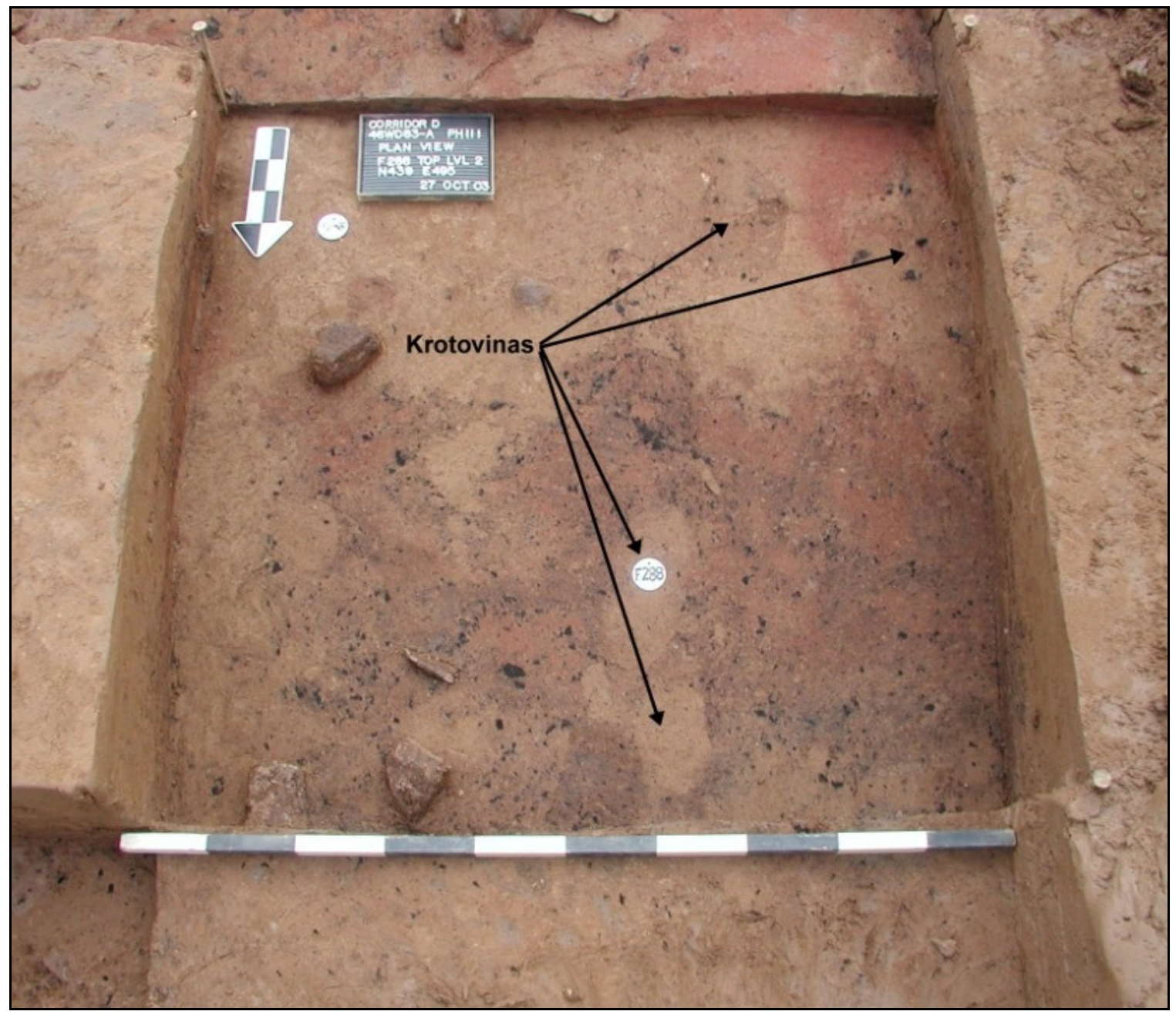

Figure 39: Plan view of portion of OC 4 showing Feature 288, a fire feature characterized by concentrated charcoal and oxidized sediment, in test unit N439 E495. Feature 288 has, for the most part, been excavated from the southern portion of the test unit, in the vicinity of the photo board, prior to the photograph. Note that the F288 tag near the center of the photo is located in a krotovina, an in-filled animal burrow. Scale bar is marked in $10 \mathrm{~cm}$ divisions; north arrow is marked $5 \mathrm{~cm}$ divisions. 


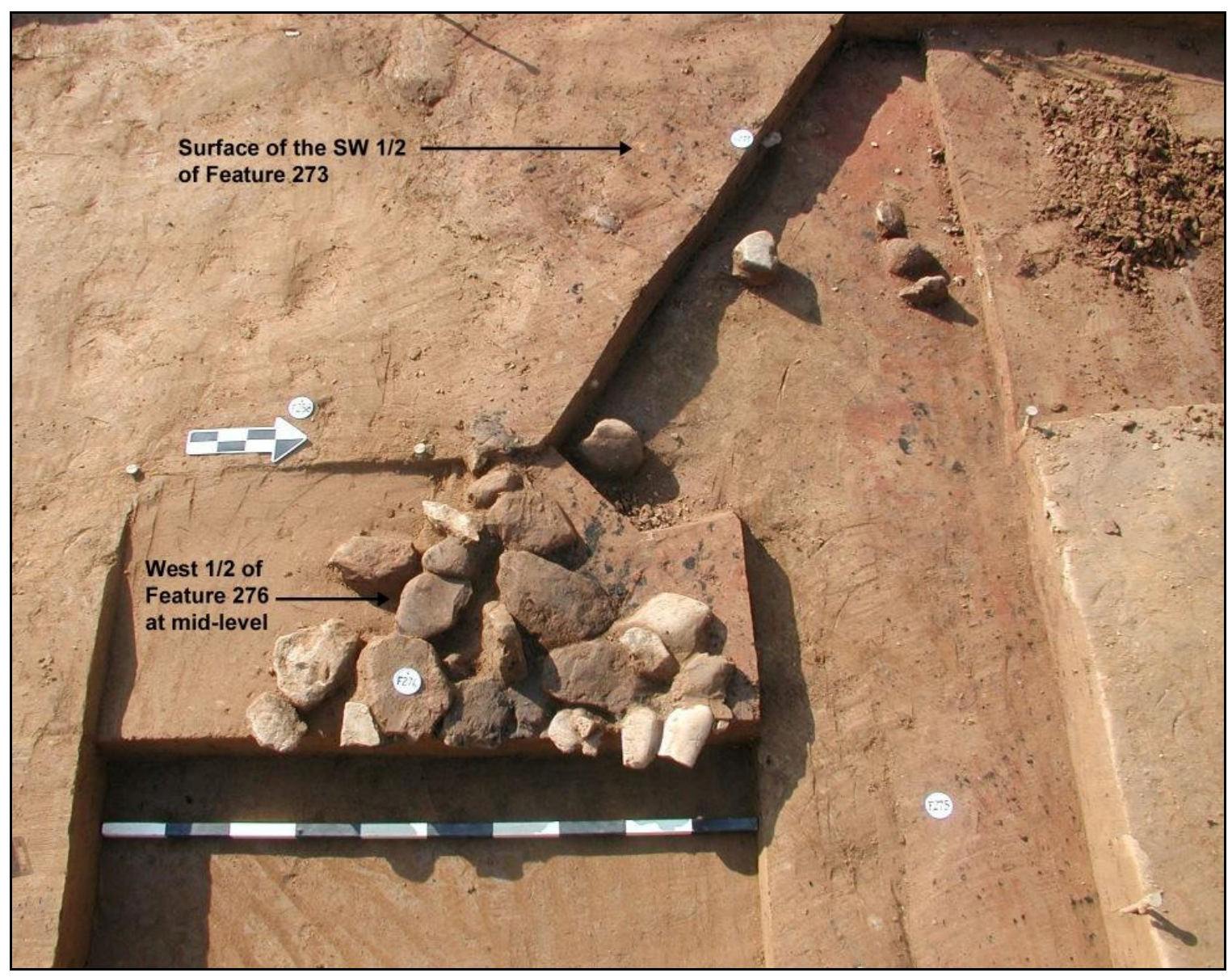

Figure 40: Plan view of portion of OC 4 showing the west half of Feature 276, a rocklined hearth, at mid-level. Photo also shows the surface of the southwest half of Feature 273 after complete removal of the northeast half. Oxidized sediments along the right of the photo are associated with Feature 288. Scale bar is marked in $10 \mathrm{~cm}$ divisions; north arrow is marked $5 \mathrm{~cm}$ divisions. 


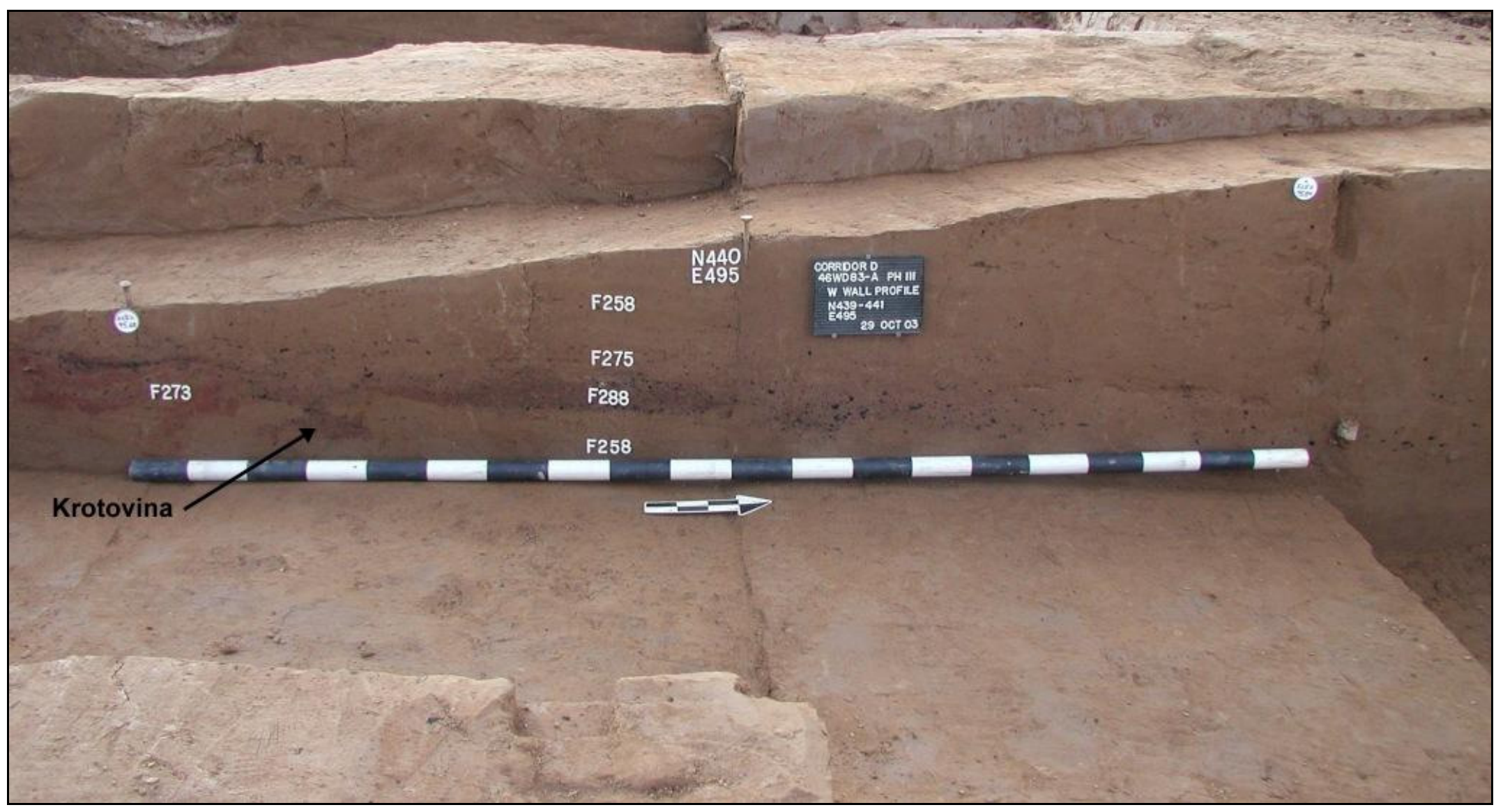

Figure 41: Profile of OC 4 along grid E495 between grid N439 and N441. Scale bar is marked in 10 cm divisions; north arrow is marked $5 \mathrm{~cm}$ divisions. The $2 \mathrm{~m}$ scale bar is oriented horizontally. 


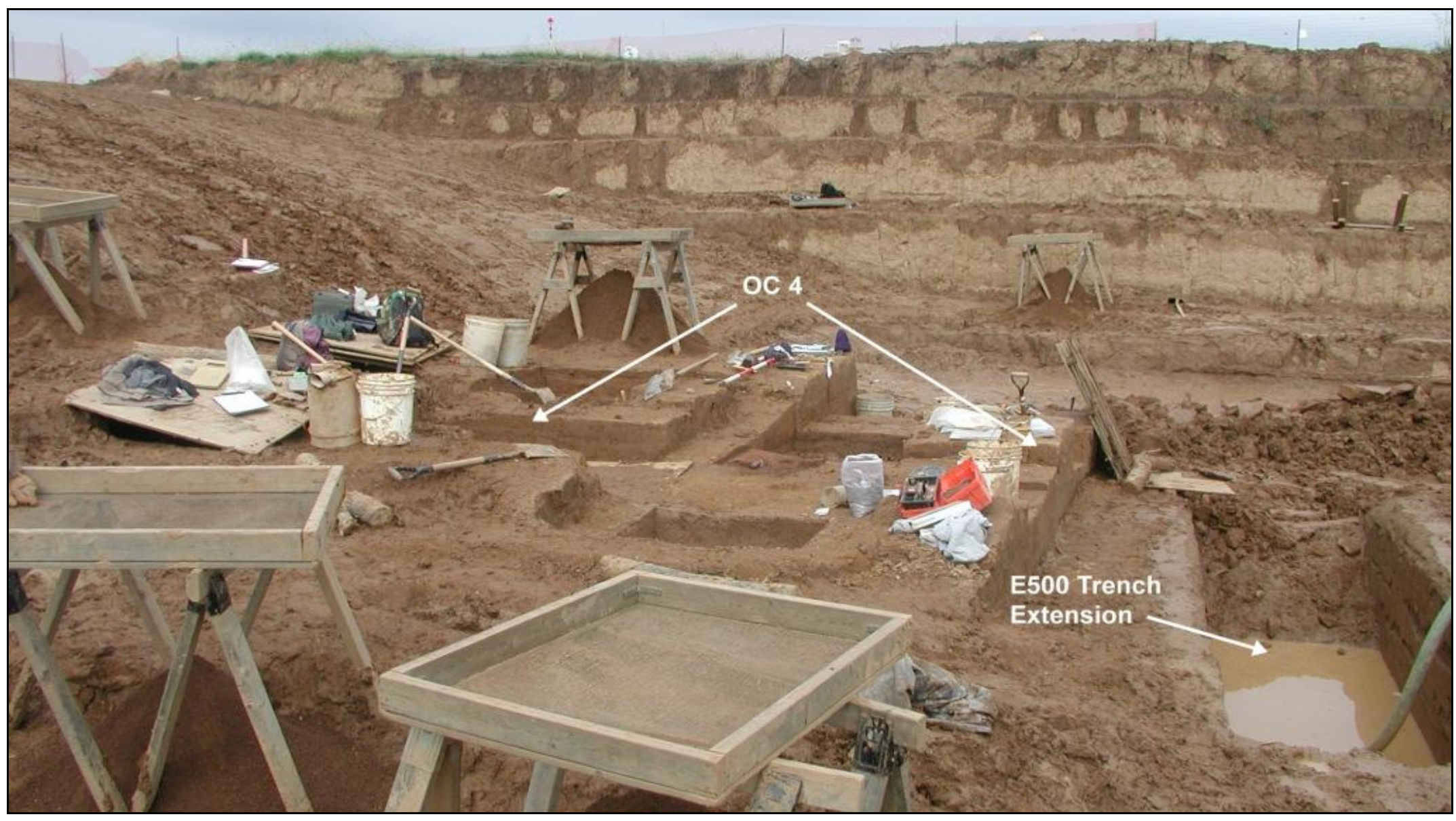

Figure 42: View of Pier 5 facing north on 28 October 2003 showing archaeological test units in OC 4. Note the E500 Trench Extension filled with water along the right of photo. 


\section{Cultural Stratum VI (CS VI)}

CS VI was identified in the deepest portions of Pier 5, the E500 Trench and E500 Trench Extension, below roughly 515 cm depth (177.07 m AMSL) at its southernmost exposure and below roughly 580 cm depth (176.42 m AMSL) in the northern exposure (Figure 28). It was further exposed in $1 \mathrm{~m} \mathrm{x} 1 \mathrm{~m}$ test units N436 E492 and N436 E495 at $\sim 531 \mathrm{~cm}$ depth (176.89 m AMSL). CS VI was sampled in two arbitrary $5 \mathrm{~cm}$ levels to 541 cm depth (176.79 m AMSL) in N436 E492 and in three arbitrary $5 \mathrm{~cm}$ levels to 546 cm depth (176.74 m AMSL) in N436 E495. CS VI coincided with, at least, the upper portion of SU 4, a sedimentary unit characterized by the presence of relatively well-preserved alluvial beds. Accordingly, the surface of CS VI corresponded with the surface of the uppermost recognizable alluvial bedding (Figure 21).

It is difficult to estimate the lateral and vertical extent of archaeological deposits in CS VI due to the limited exposure and sampling. Archaeological materials identified in CS VI were confined to the uppermost $\sim 25-30 \mathrm{~cm}$ of the stratum and were limited to two lithic artifacts in association with charcoal flecks at the base of the E500 Trench between $~ 536$ and $547 \mathrm{~cm}$ depth ( 176.84 and $\sim 176.73 \mathrm{~m}$ AMSL) and one lithic artifact recovered from CS VI in $1 \mathrm{~m} \mathrm{x} 1 \mathrm{~m}$ test unit N436 E495. Radiocarbon ages from near the base of the overlying CS V suggest that CS VI and the associated archaeological material were emplaced prior to ca. 8660 B.P.

\section{Discussion}

In proper context, alluvial sediments may serve as proxies for depositional environments. Characteristics of alluvial sediments from West Blennerhassett reflect the 
fluvial energy levels at the time of deposition. Further, fluvial energy during any specific depositional event at the site was influenced by several factors, including the proximity of the site to the active channel and the flood regime of the Ohio River during the time of deposition. It is in this context that discrete phases in the evolution of the depositional environment at West Blennerhassett are manifest as Sedimentary Units 1 through 4.

At West Blennerhassett, as at other sites in floodplain settings, alluvial sediments are the primary constituents of the matrix in which all pedological and archaeological phenomena occur. As such, sedimentary processes govern formation processes of both soils and archaeological assemblages. Furthermore, sedimentary variables are expressed in the attributes of soils and archaeological assemblages at West Blennerhassett.

Among the most prominent sedimentary variables affecting soil formation and archaeological site formation in alluvial environments is the rate at which sediment accumulates, or sedimentation rate (Ferring 1986, 1992). The effect of sedimentation rates on pedogenesis is, perhaps, best summarized by Ferring who stated “...the degree of soil profile development is inversely proportionate to rates of sediment deposition. Rapid sedimentation inhibits development of soils, while relative geomorphic stability promotes development of soil horizons” (Ferring 1992:3). With regard to the archaeological record, perhaps the most noticeable effect of sedimentation rates is the control exerted over the initial vertical spacing between archaeological deposits from successive occupations. For example, archaeological deposits from serial occupations along slowly accreting landforms will be more closely-spaced vertically than those deposited along rapidly accreting landforms (Ferring 1986; Waters 1992). Also, sedimentation rates influence the amount exposure of archaeological deposits to post-depositional 
disturbance from surficial processes. Archaeological deposits that are rapidly buried will generally be more protected from surficial processes than those that are exposed at or near the surface for longer intervals (Ferring 1986).

This section continues in two parts: (1) depositional environments and Holocene landform evolution, and (2) natural site formation processes. Each of the following sections is ordered along a spatial-temporal continuum that proceeds from oldest and deepest to youngest and most superficial. Given the importance of sedimentation and, when coupled with chronology, rates of sedimentation, on the pedogenic and archaeological records at West Blennerhassett, the sedimentology and chronology serve as the foundation on which the following discussion is structured.

\section{Deposition Environments and Holocene Landform Evolution}

The deepest levels of excavation at West Blennerhassett revealed a package of sediments (SU 4) that was apparently deposited in a dynamic, near-channel environment during the early Holocene. These sediments likely were emplaced as, or shortly after, the Ohio River transitioned from an aggrading, braided channel to an incising, meandering channel after the final retreat of glacial ice from the basin. It is surmised, based on the presence of relatively well-preserved depositional strata, that SU 4 sediments were deposited along a rapidly accreting landform. Alluvial beds in SU 4 clearly dipped northward at five percent, indicating a sloped paleolandform.

West Blennerhassett remained a dynamic depositional environment that was subject to relatively high-energy floods and slow-to-very-rapid rates of sedimentation during the emplacement of SU 3, from ca. 8660 to 7010 B.P. Even so, the site was progressing towards a more stable environment during this interval. Rapid sedimentation 
rates and coarse-textured sediments associated with SU 3 are indicative of a rapidly accreting landform in a relatively high-energy depositional environment. Minimal pedogenic alteration of SU 3 sediments, as partially evidenced by the presence of relict depositional features, further supports the notion of a rapidly accreting landform. The F44 splay deposit identified in SU 3 at Deep Test 1, as well as other coarse-textured relict depositional features, attests to the susceptibility of the early Holocene landform to relatively high-energy floods. However, the decrease in frequency of relict depositional features with increasing elevation in SU 3 is a reflection of a depositional environment that became progressively more stable with time. In addition, the subtle but discernible textural fining-upward trend, as well as an increase in abundance and decrease in separation between cultural deposits towards the top of SU 3 supports the depiction of a landform that was trending towards geomorphic stabilization. Weakly-expressed soil morphological characteristics observed throughout SU 3 indicate that, although the landform was becoming more stable, there were no extended periods of landform stability or non-deposition of sufficient duration to allow for well-developed soil horizons to form in SU 3. The distribution of archaeological deposits in SU 3, particularly the distribution of cultural features associated with OC 1 and OC 2/2A (Figure 35), indicate that the site was apparently centered along the crest of a northwest-southeast trending fluvial landform.

The rather abrupt textural break between SU 3 and SU 2 marks the transition, at ca. 7010 B.P., from a rapidly accreting, high-energy depositional environment to one that received incremental additions of alluvium from relatively low-energy overbank episodes. The shift from a relatively high-energy to relatively low-energy environment 
of deposition is likely due to vertical accretion of the landform to a threshold height above river level, possibly accompanied by lateral and vertical migration of the Ohio River channel. As the ancestral Blennerhassett Island accreted vertically, and the Ohio River incised its channel, the site would have become progressively removed from the active channel. Fine-grained textures and slow sedimentation rates throughout SU 2 attest to the low-energy nature of the depositional environment at the site during the emplacement of SU 2. Further, though the lower portion of SU 2 was devoid of archaeological deposits, close horizontal and vertical clustering of archaeological deposits in the upper portion of SU 2 is a reflection of the relatively stable nature of the site during this interval. The formation of an argillic B horizon in sediments that comprise the upper portion of SU 2 also attests to geomorphic stability at the site throughout the middle and late Holocene.

Sedimentary Unit 1 was deposited between ca. 3000 B.P. and the present. Despite extensive disturbance of SU 1 from mechanical cultivation, a distinct textural break is discerned in SU 1 from particle-size distribution data obtained from Columns 1 and 2 (Figures 15-16). There is no evidence from this study to suggest that the stratigraphic discontinuity marked by this break is a result of local lateral migration of the Ohio River in the direction of the site, a process that would potentially register in the sedimentary stratigraphy. Rather, ${ }^{14} \mathrm{C}$ ages for samples recovered from a deeply buried sand and gravel facies along the northern edge of Blennerhassett Island (Simard 1989) and in close proximity to the study area indicate that the "main channel" of the Ohio River migrated away from the site sometime prior to 5000 B.P. Furthermore, there is no reason to believe that tectonics or base level fluctuations were exerting significant control 
on the upper Ohio River in the late Holocene. As such, it is inferred that the break between SU 2 and SU 1 marks a shift in the flood regime of the Ohio River from a relatively stable overbank flood regime to a high-energy and high-magnitude flood regime. In addition, though flood magnitude and energy levels increased during the late Holocene, rates of sedimentation remained relatively unchanged from the preceding interval and suggest that there was not a concomitant increase in flood frequency.

Evidence for a late Holocene transition of the Ohio River flood regime is not unique to the stratigraphy at West Blennerhassett. A late Holocene sedimentary discontinuity registers in the alluvial stratigraphy at the Leetsdale archaeological site (36AL480), a stratified archaeological site in the Ohio River valley at river $\mathrm{km} 24$ (mi 15) near Leetsdale, Pennsylvania. At the Leetsdale site, allostratigraphic unit AU-3 dates from 3500 B.P. and is associated with episodic high discharges of the Ohio River (Schuldenrein et al. 2002; Vento et al. 2002). AU-3 overlaid allostratigraphic unit AU-2, a unit of overbank flood deposits characterized by low rates of sedimentation (Schuldenrein et al. 2002; Vento et al. 2002).

The late Holocene shift in flood regime of the upper Ohio River is likely a result of combined climatic and anthropogenic factors. The break between SU 1 and SU 2 at West Blennerhassett, as well as the break between AU-3 and AU-2 at Leetsdale, generally coincide with the onset of the a moist climatic regime, sometimes referred to as the sub-Atlantic climatic phase (cf. Wendland and Bryson 1974). Furthermore, relatively coarse-textured late Holocene sediments at Leetsdale are attributed to "greater magnitude flood events associated with large meridional cyclonic storms from the period 3000 B.P. to present” (Vento et al. 2002:49). 
The late Holocene alluvial stratigraphies at West Blennerhassett and Leetsdale compare favorably with late Holocene alluvial stratigraphies documented for the Delaware River valley in Pennsylvania. Schuldenrein (2003) demonstrated a gross correlation between phases of Holocene sedimentation and moisture regimes for several Delaware River valley archaeological sites in Pennsylvania. Schuldenrein (2003) found that phases of low sedimentation generally correspond with dry climatic cycles, and that phases of increased sedimentation correspond with moist climatic cycles. The most recent phase of increased sedimentation identified by Schuldenrein for the Delaware River valley began at 3500 B.P. and persisted to at least 1500 B.P. (Schuldenrein 2003). The interbasin similarities in the timing and nature of late Holocene sedimentation further support the premise that climatic mechanisms, at least in part, were forcing a hydrographic shift in the Ohio River at ca. 3500-3000 B.P.

Historic period anthropogenic influences on fluvial systems in North America have been well-documented, especially with regard to Euro-American land use practices (e.g. Knox 1977). At Blennerhassett Island the effects of historic period land use practices are manifest in the late Holocene coalescence of the ancestral island cluster, a phenomenon that occurred during the latter emplacement of SU 1.

The extent and timing of impact from Native American land use practices on fluvial systems are not as well documented, particularly for the upper Ohio River basin. However, there is evidence for "increasing local disturbance of the vegetation from 4800 years BP to the present” (Fredlund 1989:23) in the palynological record from Gallipolis Locks and Dam at river km 449 (mi 279) in Mason County, West Virginia. And, the emplacement of SU 1 occurred during an interval when aboriginal populations in the 
upper Ohio River basin were becoming increasingly sedentary and when subsistence strategies were progressively more related to horticulture and, later, agriculture. Archaeological sites dating from ca. 3000 B.P. are abundant throughout the upper Ohio River basin and include habitation sites as well as numerous earthworks. It is reasonable to surmise that as aboriginal populations the upper Ohio River basin became more sedentary and increasingly reliant upon horticulture and agriculture their environmental impact became more extensive and pronounced (cf. Delcourt and Delcourt 2004). Therefore, it is argued herein that anthropogenic factors, in tandem with climatic variables, are potentially responsible for the late Holocene shift in the flood regime of the Ohio River.

\section{Natural Site Formation Processes}

All archaeological deposits identified during investigations in 2002 and 2003 have been subject to varying degrees of alteration and preservation associated with sedimentary and pedogenic processes. Trends in sedimentation and soil formation have varied over time at West Blennerhassett. As such, the nature and degree of alteration and preservation of archaeological deposits at West Blennerhassett have varied concomitantly with trends in sedimentation and soil formation.

The deepest cultural deposits identified in sound context at West Blennerhassett, those associated with CS VI, were contained within relatively well-preserved, discrete depositional strata in the upper portion of SU 4. Archaeological materials in these sediments were deposited in a dynamic, rapidly accreting alluvial environment. The site was likely not conducive to long term human occupation during this time due to the frequency and magnitude of flood events. Any archaeological assemblages associated 
with CS VI occupations would, presumably, be relatively small in size and sparse in distribution, reflecting intermittent and ephemeral occupations.

Archaeological materials deposited during the CS VI interval would have been subject to alteration or erosion by fluvial processes. However, archaeological deposits in CS VI that were sealed by alluvium shortly after deposition would have been relatively protected from further post-depositional alteration. For example, the lack of soil development in the SU 4 sediments suggests that archaeological deposits in CS VI would not have been greatly affected by soil formation processes.

Archaeological deposits associated with CS V occur within the deepest portion of SU 3 and were deposited in a rapidly accreting, near-channel environment that was subject to relatively high-energy floods. Rapid rates of sedimentation in lower SU 3 have helped to seal archaeological assemblages associated with individual occupations in discrete contexts by providing increased vertical separation between serial occupations. The presence of OC 3 and OC 4, distinct occupational components identified in CS V, support this assertion.

Although the CS V archaeological deposits were sealed in discrete contexts, the same deposits were subject to disturbance from surficial process before, or shortly after, their burial. For instance, OC 3 was partially disturbed by scouring from the same splay deposit, F44, that sealed the occupational component from further post-depositional disturbance. Additionally, krotovinas, in-filled animal burrows, identified in OC 4 (Figures 39 and 41) attest to the potential for disturbance of CS V archaeological deposits through bioturbation. 
Archaeological deposits associated with CS IV coincide with sediments in the upper half of SU 3 and were deposited between ca. 8075 and 7010 B.P. West Blennerhassett was still a dynamic depositional environment during this interval, but one that was becoming progressively more stable. The trend towards geomorphic stabilization resulted in decreased separation between individual archaeological assemblages and increased exposure of occupation assemblages to processes that act at or near the ground surface. Accordingly, the distinction between individual archaeological assemblages has been blurred through processes that tend to translocate artifacts between assemblages and obliterate primary depositional characteristics.

The occupational hiatus at West Blennerhassett, designated CS III, began at roughly the same time that the site became elevated above the limit of all but the highest Ohio River floods (ca. 7010 B.P.). Slow sedimentation rates and the accumulation of predominately fine-grained sediments that characterize SU 2 began coincidently with the onset of CS III and continued through the most of the occupations associated with CS II. The coarser sediments of SU 1 began to accumulate in the upper portion of CS II.

The extensive distribution and close superposition of archaeological deposits in CS II are characteristic of deposits from serial occupations occurring along a slowly accreting landform. Slow sedimentation rates resulted in diminished vertical spacing between deposits from successive CS II occupations. Prolonged exposure of the CS II archaeological deposits at or near the ground surface has made them further susceptible to alteration through pedoturbation. Soil horizonation on sediments in upper SU 2 and lower SU 1 has obliterated primary sedimentary structures, blurred the boundaries of cultural features, and obscured the primary depositional context and spatial patterns of 
archaeological assemblages associated with CS II. The net result of slow rates of sedimentation and concomitant cumulization of the soil profile is a continuum of archaeological deposits in CS II that, with the exception of relatively distinct cultural features, cannot be differentiated into occupation-specific assemblages.

The primary depositional contexts of archaeological deposits associated with CS I have been obliterated through historic period cultivation. This extensive disturbance precludes any exact determination of the affects of sedimentation and soil formation on archaeological deposits in CS I.

\section{Conclusions}

A site-specific history of Holocene landform evolution and human occupation, spanning from ca. 8660 B.P. to present, is evident in data recovered from West Blennerhassett. Distinct phases in the landform evolution at the site are reflected in the particle-size distribution of alluvial sediments. Trends in the particle-size distribution of these sediments, bolstered by a robust radiocarbon chronology, reveal aspects of the evolving environment of deposition at the site. Inferences on the nature of alluviation are further supported by pedological and archaeological data. In turn, trends in alluvial sedimentation and soil formation are referenced to explain the nature and effect of natural site formation processes on the archaeological record at West Blennerhassett.

The early Holocene denizens at West Blennerhassett occupied a rapidly accreting, near-channel environment. Archaeological deposits from prior to ca. 7010 B.P. were subject to erosion from frequent high-energy floods. However, archaeological assemblages that were not eroded were sealed in relatively discrete contexts. The depositional environment shifted at ca. 7010 B.P. from a rapidly accreting near-channel 
environment to one that was removed from the active channel and received incremental additions of alluvium from relatively low-energy overbank discharges. The quiescent overbank flood regime persisted until ca. 3000 B.P. at the site; diminished vertical separation between archaeological deposits from serial occupations during this interval, coupled with the obliteration of primary sedimentary features from soil formation, has obscured the definition of discrete archaeological assemblages. A distinct textural discontinuity in the West Blennerhassett sedimentary stratigraphy, at ca. 3000 B.P., marks a shift in the flood regime of the Ohio River. Coarse-textured sediments deposited after ca. 3000 B.P. indicate that the site experienced flooding from relatively high-energy Ohio River discharges. However, low sedimentation rates during the late Holocene indicate that there was not a concomitant increase in the frequency of these high-energy floods at the site. Comparative data from other archaeological sites, both within and beyond the Ohio River Valley, support an assertion that the late Holocene transition in the Ohio River flood regime was spurred by climatic and anthropogenic factors.

The findings presented in this thesis have local, regional, and global implications. The site-specific findings of this research can be applied to further studies of the archaeological components and enable other researchers to infer behavior patterns from the archaeological record at West Blennerhassett. The findings of this research can also be applied to basin-wide studies to develop a model of Holocene landscape evolution and natural site formation processes. Lastly, the findings presented herein have implications that extend beyond the limits of the Ohio River basin, such as those that pertain to understanding the role of climatic and anthropogenic influences on fluvial geomorphology and alluvial stratigraphy. 


\section{References Cited}

Bell, A. M., 1986, Morphology and stratigraphy of terraces in the upper Shenandoah Valley, Virginia (M.S. Thesis): West Virginia University, Morgantown, West Virginia College of Arts and Sciences, West Virginia University, Morgantown, $161 \mathrm{p}$.

Birkeland, Peter W., 1999, Soils and Geomorphology. 3rd ed. Oxford University Press, New York.

Blott, Simon J. and Kenneth Pye, 2001, Gradistat: A grain size distribution and statistics package for the analysis of unconsolidated sediments. Earth Surface Processes and Landforms 26:1237-1248.

Boul, S. W., R. J. Southard, R. C. Graham, and P. A. McDaniel, 2003, Soil Genesis and Classification. 5th ed. Iowa State Press, Ames.

Chief of Engineers, 1917, Annual Reports, War Department Fiscal Year Ended June 30, 1917. Report of the Chief of Engineers U.S. Army in Three Parts, Part 2. Government Printing Office, Washington.

Delcourt, Paul A., and Hazel R. Delcourt, 2004, Prehistoric Native Americans and Ecological Change: Human Ecosystems in Eastern North America since the Pleistocene. Cambridge University Press, New York.

Dincauze, Dena F., 2000, Environmental Archaeology: Principles and Practice. Cambridge University Press, Cambridge.

District Engineer Officer, 1929, Chart Nos. 52, 53, and 54. in Ohio River: Pittsburgh, PA., to Mouth in 280 Charts and Index Sheet 1911-1914 (revised 1929). Made under supervision of the Ohio River Board of Engineers on Locks and Dams by the District Engineer Officer, Louisville, Kentucky.

D.J. Lake and Co. (publisher), 1886, Lubeck Magisterial District. in An Atlas of Wood County, West Virginia. D.J. Lake \& Company, Philadelphia.

Ellyson W. J., R. F. Fonner, and W. M. Kunkle, 1970, Soil Survey of Wood and Wirt Counties, West Virginia. United States Department of Agriculture Soil Conservation Service, U.S. Government Printing Office, Washington.

Fenneman, Nevin, M., 1938, Physiography of the Eastern United States. McGraw-Hill, New York. 
Ferring, C. Reid, 1986, Rates of fluvial sedimentation: implications for archaeological variability. Geoarchaeology: An International Journal 1(3):259-274.

Ferring, C. Reid, 1992, Alluvial pedology and geoarchaeological research. in Soils in Archaeology, edited by V. T. Holliday. pp. 1-39. Smithsonian Institution Press, Washington, D.C.

Ferring, C. Reid, 2001, Geoarchaeology in alluvial landscapes. in Earth Sciences and Archaeology, edited by Paul Goldberg, Vance T. Holliday, and C. Reid Ferring. pp.77-106. Kluwer Academic/Plenum Publishers, New York.

Fonner, Robert F., 1984, Soils of Blennerhassett Island. Appendix A in Phase I archaeological investigations, U.S. Rt. 50 Relocation at Blennerhassett Island, Wood County, West Virginia, by Daniel B. Fowler and Jeffery R. Graybill. Blennerhassett Historical Park Commission, Parkersburg, West Virginia, Report Prepared for the West Virginia Department of Highways, Charleston, West Virginia.

Fowler, Daniel B., and Jeffery R. Graybill, 1984, Phase I archaeological investigations, U.S. Rt. 50 relocation at Blennerhassett Island, Wood County, West Virginia. Blennerhassett Historical Park Commission, Parkersburg, West Virginia, Report Prepared for the West Virginia Department of Highways, Charleston, West Virginia.

Fredlund, Glen G., 1989, Holocene vegetational history of the Gallipolis Locks and Dam Project Area, Mason County, West Virginia. Cultural Resource Analysts, Inc. Contract Publication Series 89-01.

Grantz, Denise L., Keith R. Bastianini, J. Steven Kite, William C. Johnson, Deborah E. Casselberry, and Edward J. Siemon III, 2002, Preliminary phase I archaeological investigations in the Appalachian Corridor D study area Wood County, West Virginia: management summary letter report: Section 2 Blennerhassett Island river crossing. Submitted by Michael Baker Jr., Inc., Coraopolis, Pennsylvania, and Charleston, West Virginia, to the West Virginia Department of Transportation, Division of Highways, Charleston.

Harris, Edward C., 1989, Principles of Archaeological Stratigraphy. 2nd ed. Academic Press, London.

Hassan, Fekri A., 1978, Sediments in archaeology: methods and implications for paleoenvironmental and cultural analysis. Journal of Field Archaeology 5(2):197213.

Hemmings, E. Thomas, 1977, Neale's Landing: an archeological study of a Fort Ancient settlement on Blennerhassett Island, West Virginia. West Virginia Geological and Economic Survey, Morgantown, Open File Report 0F807, Submitted to the 
West Virginia Antiquities Commission and the Office of Archeology and Historic Preservation, Department of the Interior - National Park Service, National Park Service Project No. 54-73-00020-00.

H.C. Nutting Company, 2004, Final report of geotechnical study: Blennerhassett Bridge - short span tied arch alternate Appalachian Corridor D over Ohio River and Blennerhassett Island. State Project No. X354-D-0.00 02, Federal Project No. APD-0282(128) C, Wood County, West Virginia. For Michael Baker Jr., Inc., Charleston, WV. Performed by H.C. Nutting Company.

Holliday, Vance T., 2001, Quaternary geosciences in archaeology. in Earth Sciences and Archaeology, edited by Paul Goldberg, Vance T. Holliday, and C. Reid Ferring, pp. 3-35. Kluwer Academic/Plenum Publishers, New York.

Holliday, Vance T., 2004, Soils in Archaeological Research. Oxford University Press, New York.

Johnson, William C., Denise L. Grantz, and Ryan W. Robinson, 2003, Appalachian Corridor D, West Blennerhassett Site (46WD83-A) phase III excavations. End of fieldwork summary letter. Submitted by Michael Baker Jr., Inc., Coraopolis, Pennsylvania, and Charleston, West Virginia, to the West Virginia Department of Transportation, Division of Highways, Charleston.

Jones, R. R., 1920, The Ohio River: Charts, Drawings, and Description of Features Affecting Navigation. War Department Rules and Regulations for the River and its Tributaries. Navigable Depths and Tables of Distances for Tributaries. Compiled under direction of the Chief of Engineers, United States Army, and the District Engineer, First District, Cincinnati, Ohio [1916, revised to March 31, 1920].

Kite, J. Steven and A. Bell, 1992, Particle-size analysis at the Quaternary Geology Laboratory, West Virginia University. in Laboratory methods at the Quaternary Geology Laboratory, West Virginia University, preliminary draft, edited by J. Steven Kite. West Virginia University Quaternary Geology Publication 1. Department of Geology and Geography, West Virginia University, Morgantown, WV.

Kite, J. Steven, Ryan W. Robinson, William C. Johnson, and Eric N. Davis, 2006, Geoarcheological framework for deeply stratified Archaic terrace sites in the upper Ohio River basin (abstract). Geological Society of America, Abstracts with Programs 38(7):453.

Knox, James C., 1977, Human impacts on Wisconsin stream channels. Annals of the Association of American Geographers 67(3):323-342.

Nikiforoff, C. C., 1949, Weathering and soil evolution. Soil Science. 67(3):219-230. 
Rapp, George (Rip), and Christopher L. Hill, 2006, Geoarchaeology: The Earth-Science Approach to Archaeological Interpretation. 2nd ed. Yale University Press, New Haven and London.

Rector, Charles R., 1932, The genesis of Blennerhassett Island. The West Virginia Review 9(12):472-474. Charleston.

Robinson, Ryan W., William C. Johnson, Bryan C. Cunning, Denise Grantz Bastianini, and Edward J. Siemon III, 2008, Archaeological investigations at the West Blennerhassett Site (46WD83-A). With contributions by Michael L.

Kagelmacher, Keith R. Bastianini, Martin T. Fuess, Andrew P. Bradbury, Leslie L. Bush, Kathryn Puseman, and Linda Scott Cummings (draft report). Michael Baker Jr., Inc., Moon Township, Pennsylvania, and Charleston, West Virginia. Prepared for the West Virginia Department of Transportation, Division of Highways, Charleston.

Rogers, Randall L., Jr., 1990, Late Quaternary stratigraphy and geologic history of the upper Ohio River Valley, near Gallipolis Locks and Dam (M.S. thesis). West Virginia University, Morgantown.

Schaetzl, Randall J., and Sharon Anderson, 2005, Soils: Genesis and Geomorphology. Cambridge University Press, Cambridge.

Schiffer, Michael B., 1983, Toward the identification of formation processes. American Antiquity 48(4):675-706.

Schiffer, Michael B., 1987, Formation Processes of the Archaeological Record. University of Utah Press, Salt Lake City.

Schuldenrein, Joseph, 2003, Landscape change, human occupation, and archaeological site preservation at the glacial margin: geoarchaeological perspectives from the Sandts Eddy Site (36Nm12), middle Delaware Valley, Pennsylvania. in Geoarchaeology of Landscapes in the Glaciated Northeast, edited by David L. Cremeens, and John P. Hart, pp. 181-210. New York State Museum Bulletin 497. The University of the State of New York, Albany.

Schuldenrein, Joseph, Frank Vento, and Suanna Selby, 2002, Interim geomorphological report for archaeological site 36AL480, Area 3 South, Leetsdale Industrial Park, Leetsdale, Allegheny County, Pennsylvania (draft report). Prepared by Geoarcheology Research Associates, Inc. for Geenhorne and O’Mara under contract to U.S. Army Corps of Engineers, Contract No. DACW 59-01-T-0028.

Simard, Claudette M., 1989, Geologic history of the lower terraces and floodplains of the upper Ohio River Valley (M.S. thesis). West Virginia University, Morgantown. 
Soil Survey Staff, 1999, Soil Taxonomy: A Basic System of Soil Classification for Making and Interpreting Soil Surveys. 2nd ed., Agricultural Handbook No. 436. United States Department of Agriculture, Natural Resources Conservation Service, Washington, D.C.

Soil Survey Staff, 2008a, Soil Survey at West Blennerhassett. Web Soil Survey (Online WWW). Available URL:

"http://websoilsurvey.nrcs.usda.gov/app/WebSoilSurvey.aspx" (Accessed 28 April 2008).

Soil Survey Staff, 2008b, Official Series Descriptions (Online WWW). Available URL: "http://soils.usda.gov/technical/classification/osd/index.html" (Accessed 4 April 2008).

Stein, Julie K., 2001, A review of site formation processes. in Earth Sciences and Archaeology, edited by Paul Goldberg, Vance T. Holliday, and C. Reid Ferring, pp.37-51. Kluwer Academic/Plenum Publishers, New York.

Swick, Ronald. R., 1975, History of Blennerhassett Island. Unpublished manuscript. Johnson, Johnson, and Roy, Inc., Ann Arbor, Michigan.

U.S. Army Corps of Engineers, 1934, Sheet Nos. 23 and 24. in Ohio River Aerial Survey, Powhatan Point, O. to Catlettsburg, KY in 60 Sheets (photographed between October 1931 and February 1932). U.S. Engineer Office, Huntington, W. VA.

Vento, Frank, J., Joseph Schuldenrein, and Matthew P. Purtill, 2002, Geomorphology of archaeological site 36AL480 at Leetsdale Industrial Park, Leetsdale, Allegheny County, Pennsylvania (final report). Prepared for U.S. Army Corps of Engineers, Contract No. DACW59-99-D-0015.

Waters, Michael R., 1992, Principles of Geoarchaeology: A North American Perspective. The University of Arizona Press, Tucson.

Wendland, Wayne M., and Reid A. Bryson, 1974, Dating climatic episodes of the Holocene. Quaternary Research 4:9-24. 


\section{Appendix}

Particle-size analysis worksheets link

Digitally signed by John H. Hagen

Reason: I am approving this

Date: 2009.04.20 12:00:10 -04'00' 